Florida International University FIU Digital Commons

\title{
Transnational Capitalism and the Middle East: Understanding the Transnational Elites of the Gulf Cooperation Council
}

Seyed Ahmad Mirtaheri

Florida International University, ahmad.mirtaheri@gmail.com

DOI: $10.25148 /$ etd.FIDC000717

Follow this and additional works at: https://digitalcommons.fiu.edu/etd

Part of the Comparative Politics Commons, International Relations Commons, Political Economy Commons, and the Regional Economics Commons

\section{Recommended Citation}

Mirtaheri, Seyed Ahmad, "Transnational Capitalism and the Middle East: Understanding the Transnational Elites of the Gulf Cooperation Council" (2016). FIU Electronic Theses and Dissertations. 2607.

https://digitalcommons.fiu.edu/etd/2607 


\title{
FLORIDA INTERNATIONAL UNIVERSITY
}

Miami, Florida

TRANSNATIONAL CAPITALISM AND THE MIDDLE EAST:

UNDERSTANDING THE TRANSNATIONAL ELITES OF THE

GULF COOPERATION COUNCIL

\author{
A dissertation submitted in partial fulfillment of the \\ requirements for the degree of \\ DOCTOR OF PHILOSOPHY \\ in \\ POLITICAL SCIENCE \\ by
}

Seyed Ahmad Mirtaheri

2016 
To: Dean John Stack

Green School of International and Public Affairs

This dissertation, written by Seyed Ahmad Mirtaheri, and entitled "Transnational Capitalism and the Middle East: Understanding the Transnational Elites of the Gulf Cooperation Council", having been approved in respect to style and intellectual content, is referred to you for judgment.

We have read this dissertation and recommend that it be approved.

$\begin{array}{r}\hline \text { Mohiaddin Mesbahi } \\ \hline \text { Jin (Julie) Zeng } \\ \hline \text { Benjamin Smith } \\ \hline \text { Ronald W. Cox, Major Professor }\end{array}$

Date of Defense: May 6, 2016

The dissertation of Seyed Ahmad Mirtaheri is approved.

Dean John Stack

Green School of International and Public Affairs

Andrés G. Gil

Vice President for Research and Economic Development and Dean of the University Graduate School

Florida International University, 2016 
(C) Copyright 2016 by Seyed Ahmad Mirtaheri

All rights reserved. 


\section{DEDICATION}

To Ronald W. Cox 


\title{
ABSTRACT OF THE DISSERTATION \\ TRANSNATIONAL CAPITALISM AND THE MIDDLE EAST: UNDERSTANDING \\ THE TRANSNATIONAL ELITES OF THE GULF COOPERATION COUNCIL
}

\author{
by
}

Seyed Ahmad Mirtaheri

Florida International University, 2016

Miami, Florida

\section{Professor Ronald W. Cox, Major Professor}

In this dissertation, I argue that transnational elites within the Gulf Cooperation Council (GCC) have been integrated within a Transnational Capitalist Class (TCC) economically, militarily and politically through relationships that transcend the boundaries of the nation-state. These relationships exist within the context of a global capitalist structure of accumulation that is dependent on the maintenance of a repressive state apparatus in the GCC. There have been few attempts to analyze the relationships that Middle Eastern political and economic elites have developed with global elite networks. This work fills an important gap in the scholarly literature by linking the political and economic power of the GCC elites to transnational capitalist class actors in the U.S. and Western Europe.

The TCC is comprised of actors who derive their wealth and power from ownership of production or financial activities on a global scale. The embeddedness of GCC elites within the TCC came with the de-centralization of capital accumulation occurring from the 1970s through the present that has linked regional and local capitalists to the ownership activities of transnational capitalist firms. The GCC is an important case study for analyzing 
the structure and consequences the current phase of globalization due to its relative importance in providing resources and financing for transnational globalization. Therefore this project contributes to our assessment of the role played by transnational elites in the GCC and the regional and global consequences of their power struggles based in part on a theoretical framework derived from Neo-Gramscianism. 


\section{TABLE OF CONTENTS}

CHAPTER $\quad$ PAGE

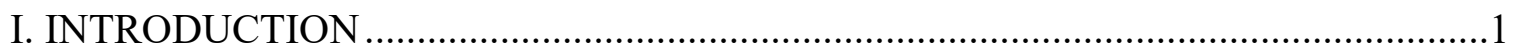

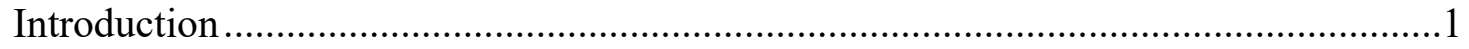

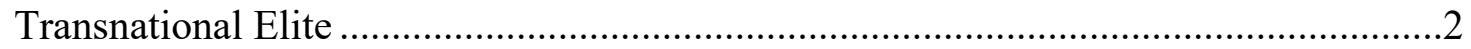

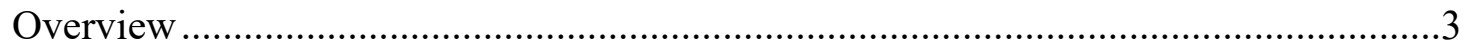

Literature Review and Theoretical Framework ......................................................

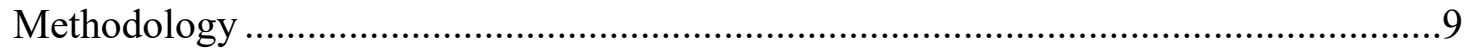

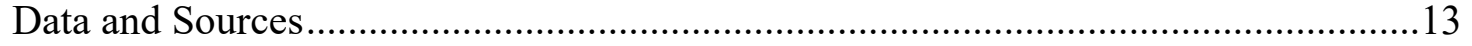

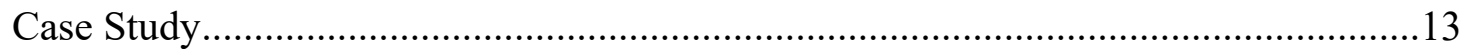

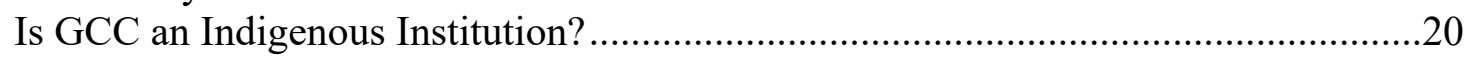

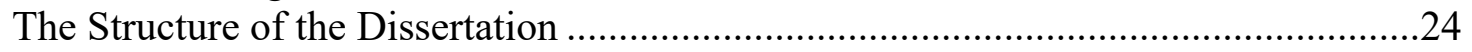

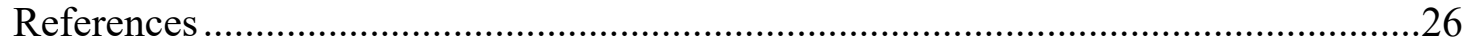

II. THE POLITICAL ECONOMY OF A TRANSNATIONAL ELITE IN THE GCC ....29

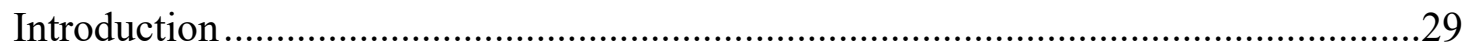

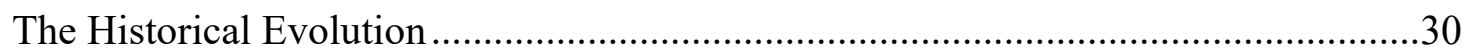

The Emergence of a GCC Transnational Elite............................................................35

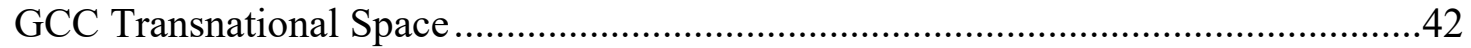

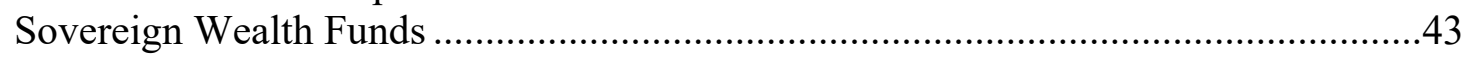

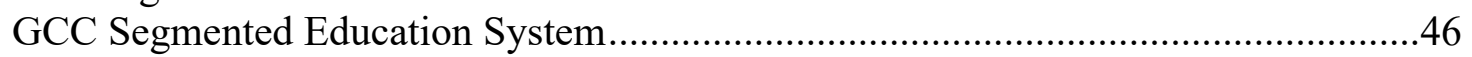

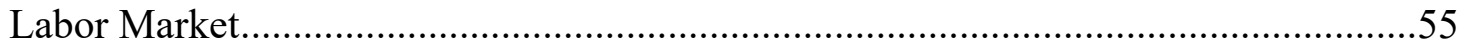

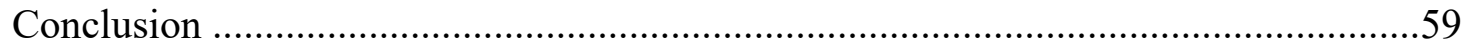

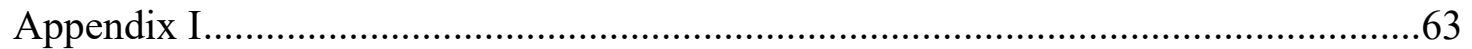

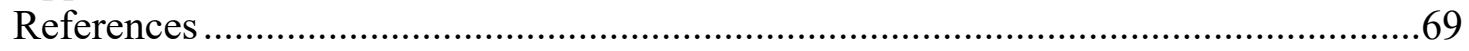

III. THE FRAMEWORK FOR CONNECTIONS BETWEEN THE GCC

TRANSNATIONAL ELITES AND THE TCC CONNECTIONS................................72

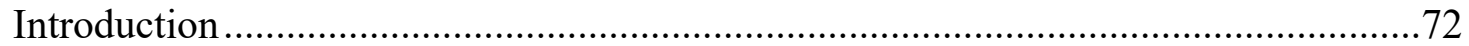

Nationalization of Oil and the Emergence of GCC Transnational Elites ......................74

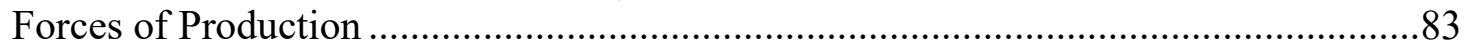

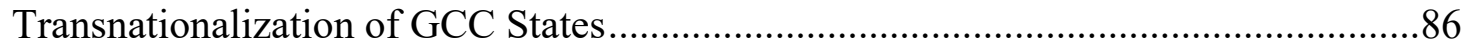

The Financial Power of the GCC Elites ..................................................................

The Historical Background of GCC Financialization................................................99

The Essence of the GCC's Financial Power .......................................................100

Small Financial Sector, But Important.................................................................106

The GCC's Role in Global Financial Institutions ...................................................111

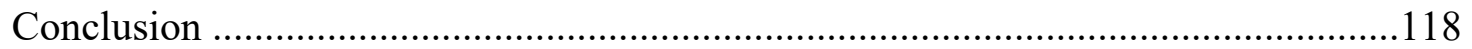

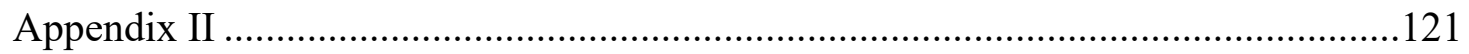

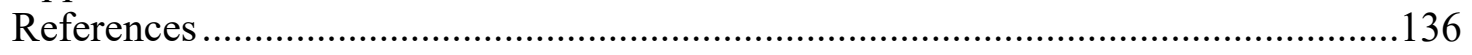




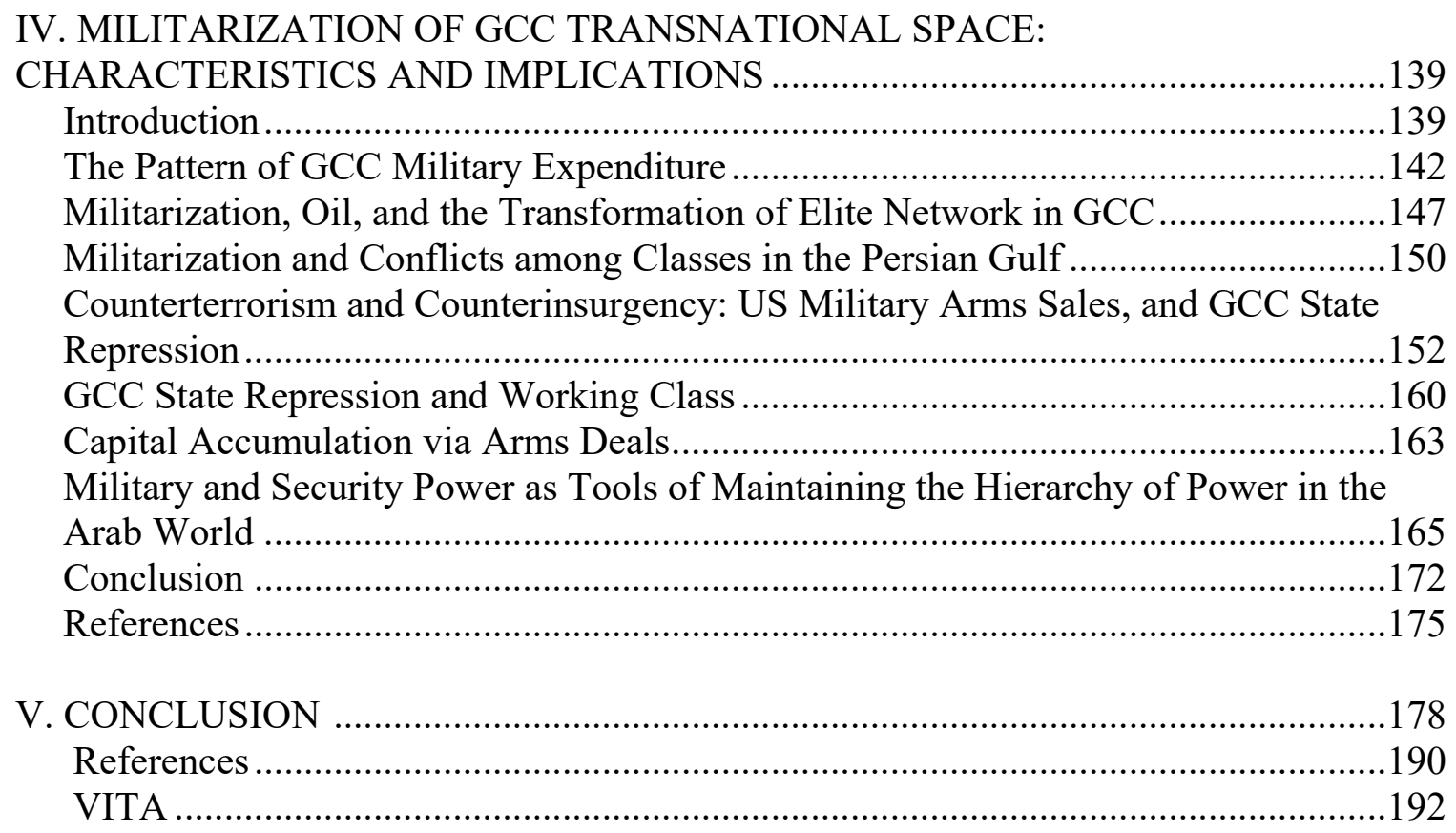




\section{LIST OF TABLES}

TABLE

PAGE

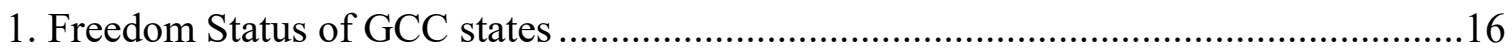

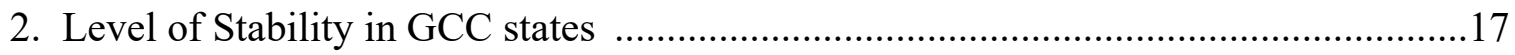

3. The Level of Stability in the rest of Middle Eastern States .........................................18

4. The GCC Sovereign Wealth Funds (SWFs) ………………..................................44

5. The Educational Background of Major Economic and Political Figures in the GCC ...48

6. Dubai Schools with Western Curricula ………………............................................49

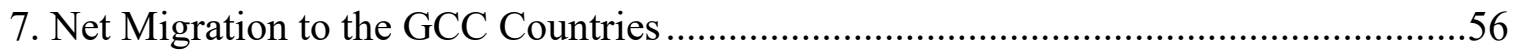

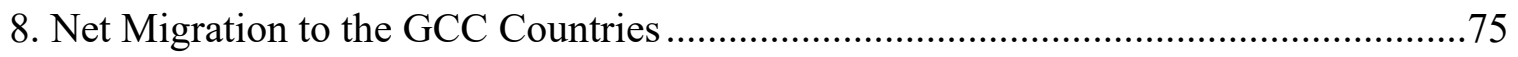

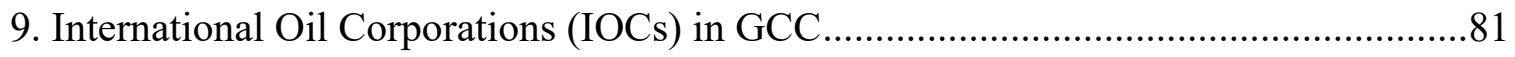

10. Important GCC Conglomerates and their Activities ....................................................89

11. GCC Total Oil Supply (Thousand Barrels Per Day) ……….......................................104

12. Domestic credit provided by financial sectors (\% of GDP) .......................................107

13. GCC-SWF Capital Infusions into Financial Institutions ............................................109

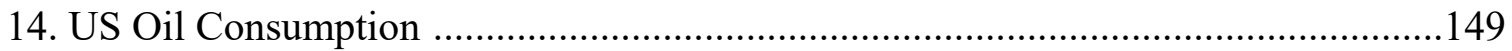

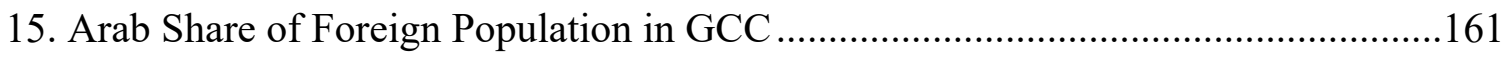

16. Freedom Status in Egypt, Bahrain, and Tunisia ……….........................................171 


\section{LIST OF FIGURES}

\section{FIGURE}

PAGE

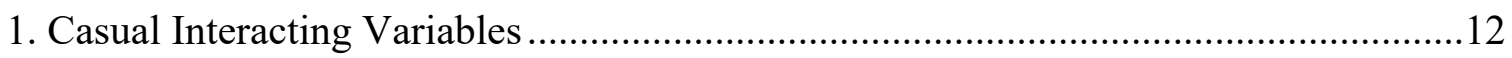

2. Trend Line of Net Migration in the GCC Countries ................................................57

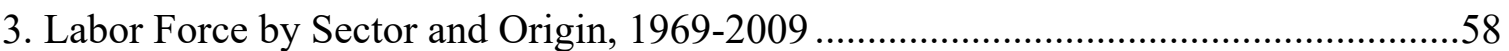

4. The Economic and Family Ties Between Merchant Families and Royal Families in

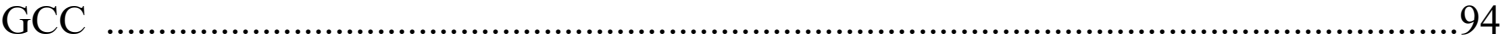

5. The Geographical Networks of GCC Conglomerates ..........................................97

6. The Chinn-Ito Index for Financial Openness for GCC and World...........................117

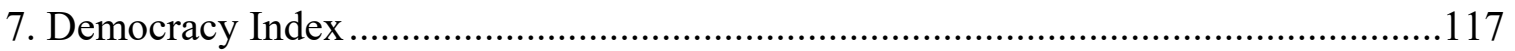

8. Military Deals by Persian Gulf States and The Sellers ..........................................146

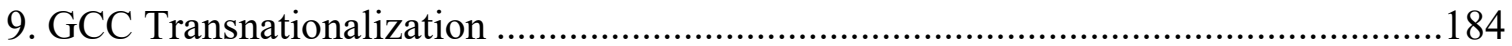




\section{LIST OF CHARTS}

2. Gulf states are increasingly — and almost completely — dependent on oil revenues for their national budgets

3. Amount of Contributions in NAB by Country ...................................................114

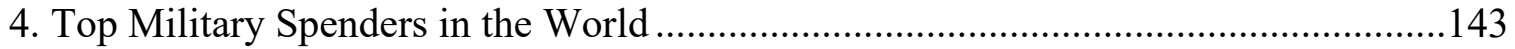

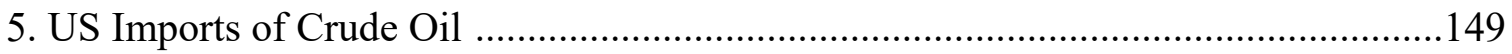

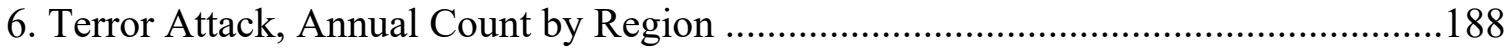




\section{ABBREVIATIONS AND ACRONYMS}

\begin{tabular}{|c|c|}
\hline GAB & General Arrangements to Borrow \\
\hline $\mathrm{GCC}$ & Gulf Cooperation Council \\
\hline GDP & Gross Domestic Product \\
\hline HRW & Human Rights Watch \\
\hline IAEA & International Atomic Energy Agency \\
\hline $\mathrm{ICC}$ & International Chamber of Commerce \\
\hline ICTs & Information and Communications Technologies \\
\hline IFC & International Finance Corporation \\
\hline ILO & International Labor Organization \\
\hline IMF & International Monetary Fund \\
\hline IOC & International Oil Corporation \\
\hline IOM & International Organization on Migration \\
\hline IOS & International Organization of Standardization \\
\hline IWG & International Working Group \\
\hline MEFTA & Middle East Free Trade Area Initiative \\
\hline MENA & Middle East and North Africa \\
\hline $\mathrm{MNC}$ & Multinational Corporation \\
\hline NAB & New Arrangements to Borrow \\
\hline NATO & North Atlantic Treaty Organization \\
\hline $\mathrm{NOC}$ & National Oil Corporation \\
\hline OPEC & ganization of the Petroleum Exporting Countries \\
\hline
\end{tabular}


SWF

TCC

TCP

TNC

TNP

TNS

WCO

WML

WTO
Sovereign Wealth Fund

Transnational Capitalist Class Technical Cooperation Program

Transnational Corporation

Transnational Practices

Transnational State

World Customs Organization

World Muslim League

World Trade Organization 


\section{CHAPTER I \\ INTRODUCTION}

\section{Introduction}

Much of the literature on the Middle East focuses on either institutional arrangements or culture. There have been few attempts to analyze the relationships that Middle Eastern political and economic elites have developed with global elite networks. This work represents a significant departure from contemporary scholarship by analyzing the extent to which Middle Eastern elites within the Gulf Cooperation Council (GCC) are linked to the transnational capitalist class (TCC) in the rest of the world economy. The TCC is composed of actors who derive their wealth and power from ownership of production or financial activities on a global scale. Indeed, the argument advanced here is that Middle Eastern elites have been integrated within a global transnational class that has disproportionate power and influence within the world system. Therefore, I will analyze the intersection between the transnational elites within the GCC and the TCC within a global social structure of accumulation. I will also show how this global structure of accumulation is tied to the maintenance of a repressive state apparatus in the GCC.

One can analyze the influence of the TCC on the GCC in a deterministic way. This analysis is crucial when studying the GCC not only as a model of how the TCC is embedded in this sub-region, but also as a methodological foundation that can provide a better understanding of possible impact of the GCC on global capitalism. The following sections propose a systematic framework of the linkage between GCC-based elites and the TCC. This study is the first of its kind in the literature on the Middle East, and it is especially relevant because GCC-based elites continually reflect the TCCs' goals and 
agendas, which are mainly those of the United States and United Kingdom. Before explicating the propositions being tested in this dissertation, it is necessary to explain the definitions and notions pertaining to transnational elites and the TCC.

\section{Transnational Elites}

The recent trend in global capitalism may be understood as the integration of various capitalist classes into a global class - a transnational capitalist class (TCC). This integration is taking place simultaneously with a fast-paced global integration in the financial and trade sectors that is partly facilitated by advances in information technologies. In his book, Transnational Conflicts: Central America, Social Change and Globalization William Robinson explains the significant role played by transnational and transnationallyoriented elites, and he has coined the term transnational capitalist class to refer to those elites. Robinson contends:

"As the agent of global economy, transnational capital has become the hegemonic fraction of capital on a world scale. Here fraction denotes segments within classes determined by their relation to social production and the class as a whole. The new transnational bourgeoisie or capitalist class is that segment of the world bourgeoisie that represents transnational capital. . . This class is transnational because it is tied to globalized circuits of productions, marketing, and finances unbound from particular national territories and identities, and because its interests lie in global over local or national accumulation.” (Robinson, 2003, P. 39).

In this dissertation, the notions of transnational capitalist elites and Robinson's TCC will serve as foundational concepts. This dissertation will (1) synthesize the existing 
definitions of the notion of a transnational class of elites in the literature, (2) offer its own account of what constitutes the current transnational capitalist elites, and (3) define boundaries of the TCC and the nature of its activities.

The transnational elites of the Middle East are connected to TCC networks. Some elites are part of the TCC class due to their ownership or accumulation activities; others belong to a political class of elites due to their functions within a repressive apparatus of the state. These political elites might not own capital, but they are important for maintaining stability in their own domestic realm, which also helps global capitalists accumulate profits. This study will attempt to show how Middle Eastern transnational elites are integral to the project of a transnational capitalist class that increasingly relies on the various repressive state apparatus within in the Persian Gulf region. At the same time the transnational elites of the GCC are themselves represented as significant actors within the larger transnational capitalist class, profiting from this relationship through their participation in mutual profit-making ventures and through their membership in global transnational institutions.

\section{Overview}

The ruling class and elites of the GCC comprise important sectors of the TCC. This dissertation, therefore, begins with an attempt to define and analyze what and who constitutes the transnational elites in the GCC, partly based on some general characteristics of this class as identified in the literature and synthesized in this dissertation. Next, the dissertation explores the implications of the TCC, especially pertaining to the interactions between this class and the ruling class in Persian Gulf Arab states. To the extent that the GCC's economy and financial resources are important for Western economies, a better 
understanding of this region's transnational elites could lead to a better understanding of some of the political strategies and processes implemented in Western powers' foreign policies. As mentioned before, studying the GCC's transnational elites sheds valuable light on some of the understudied aspects of today's global economy.

\section{Literature Review and Theoretical Framework}

This dissertation is primarily based on historical structuralism. Arguably, the transnational elites in the GCC are connected to the TCC due to their position within a global structure of accumulation. Such a position is analyzed in terms of the financialization and internationalization of GCC capital. Certain approaches that have emerged based on historical structuralism could help in terms of tracing the features and functions of such interconnectedness. In the following sections, I will address those core insights that are useful for this research project. In each chapter I will further elaborate by linking those insights to other literatures that are related to the specific argument of the chapter; for instance, the literature on militarization in Chapter 4. Generally, the analysis in this dissertation primarily employs David Harvey's approach to studying historical structuralism, in conjunction with Robert Cox's neo-Gramscian theory of politics. Harvey's approach may be understood as an example of what is called, somewhat broadly, neo-Marxian theories and/or neo-Marxism. Neo-Marxism, according to Cox, emphasizes the relationship between three factors: "social forces," "forms of state," and the "world order." In particular, the world order refers to the "current organization of International Relations," which includes the relationship among states, international law, and international institutions. More specifically, the contemporary world order has been organized with the establishment of a series of influential institutions including the United 
Nations (UN), as well as those institutions that emerged under the Bretton Woods Agreement, the World Bank, the International Monetary Fund (IMF), and the Bank of International Settlements. This dissertation will also use the concept of "forms of state" to analyze the internationalization of GCC states based on class-based analysis. "Forms of state" refers to the evolution of states through their relationship with various social forces released or suppressed within a capitalist system. In this context, neo-liberalization (as a structure that has released certain forces in the international system) entails "challenging traditional forms of state sovereignty" (Harvey, 2005, P.3). Finally, in terms of the social forces present in the process of capitalist production, Harvey notes that "Neoliberal rhetoric, with its foundational emphasis upon individual freedoms, has the power to split off libertarianism, identity politics, multiculturalism, and eventually narcissistic consumerism from the social forces ranged in pursuit of social justice through the conquest of state power" (Harvey, 2005, P. 41). All these key concepts will be employed in this dissertation research to better understand the role of regional transnational elites in the GCC.

In terms of the financial aspect of current capitalism, this research recognizes that globalization, itself, has been experiencing notable transformations. One significant differentiating factor among the various stages of globalization has been the different patterns (as well as levels) of functional integration in the global economy that are promoted by the by the process of transnationalization. Evidently, the pattern of functional integration at each time is also influenced by the existing and dominant mode of production at that time. The economic integration during colonialism had different characteristics from the globalization that emerged after the Second World War. The same may be said about 
the Bretton Woods system and the post-Bretton Woods system within the post-War context. Robert Wade has identified three important implications of the Bretton Woods system related to the restrictions on capital flows and the fixed exchange rate, which were the cornerstones of the system. The first implication was in the realm of international trade; namely "[the] backing of the main international currencies by gold tended to check persistent trade imbalances". Second, the Bretton Woods system was a system in which "private international capital flows were small," by default and by design. The third implication was that main economic parameters in the system proved to be steady (Wade, 2006, P. 116).

None of these three elements may be found on the same level in the post-Bretton Woods system; and the difference may, in important parts, be explained by various structures of global functional and financial integration - a structure that was shaped, inter alia, by collective decisions of powerful economic classes in order to "generate conditions more favorable to the transnational elite agenda" (Robinson, 2005, P. 13).

The collapse of the Breton Woods system resulted in an ever-increasing amount of international private capital. This, in turn, has made the financial sector a significant sector (if not the most significant sector) in the global economy. Accordingly, the power struggles of the TCC within this sector may be viewed as a new and powerful politico-economic phenomenon that had not existed in the earlier patterns of globalization. Thus, in order to understand the notion of transnational elites and their impact on the global economy, it is necessary to analyze the dominant economic paradigm in terms of production, financial integration and trade. In order to explore this paradigm, which constitutes the foundation for actions of the transnational capitalist class, this study uses two insightful analyses by 
Robinson (on the notion of "transnational elites") and by Cox (on the current phenomenon of "financialization of production").

According to Robinson, we have been witnessing the transformation of the role played by elites within the new pattern of the global economy. While the previous pattern of the global economy was based on the notion of accumulation (in a nationally-oriented sense of the term), the new pattern of the global economy is moving towards a transnationally-oriented arrangement in which transnational elites play a key role. The nationally-oriented context of elites" activities often followed "policies that would protect local agents from global competition" (Robinson, 2010, P.1). In contrast, the new generation of transnational elites' activities is based on the integration of "local circuits into new transnational circuits of accumulation" (Robinson, 2010, P. 1). Partly based on what Robinson has identified as the key changes within the capitalist class structure, this dissertation aims to offer a new account of the transnational elites of the GCC that strategically, organizationally, and financially are more internationally-oriented than locally-oriented. My theoretical framework, therefore, shares much with Robinson's understanding of the evolution of transnational elites. I borrow less from those authors who are sometimes called skeptical internationalists or from those who view globalization as a more or less consistent phenomenon over a long history. I agree with Robinson, who sees:

“... globalization as a qualitatively new epoch in the ongoing evolution of world capitalism, characterized above all by the rise of truly transnational capital and the integration (or re-articulation) of most countries in the world into a new global production and financial system". (Robinson, 2010, P. 2) 
The liberalization of financial markets that took place in the post-Bretton Woods era has been an important force in what is sometimes called an unfettered globalization. The qualitatively different structure of today's financial markets is indeed a hallmark of post-Cold War globalization. The far-reaching consequences of these new markets, which will impact generations to come, cannot be overstated. As Cox argues, we have been witnessing the spectacle of financialization of production (mis)represented as a new mode of production. Yet, the new mode of production reveals similar crises as the former ones. According to Cox, the financialization of production refers to:

"[T]he extent to which non-financial transnational corporations have become more dependent on an accumulation of financial assets, and on relationships to institutional financial investors, to maintain their dominant position within the contemporary global production system. ... [T] his process started aggressively in the U.S. but has been adopted and expanded as a model for corporate behavior elsewhere. As a result, today's corporate profits are much more firmly tied to the financial sector." (Cox, 2012, pp. 5, 188)

Following a more in-depth analysis of the above theoretical frameworks, this dissertation aims to trace and analyze the financial connections between the Persian Gulf Arab states, on the one hand, and Western banking systems, on the other. This research intends to offer an example of how to apply the above theoretical framework to the facts of a real case study, with the hope that these transnational elites and their internal and external financial relations are better understood.

Thus, this research will explore evidence of an interrelationship and mutual dependence between GCC elites and a transnational capitalist class. Such a crucial link 
between GCC-based elites and TCC can be demonstrated by examining their joint economic and political ventures on a global scale. The methodology that I use provides empirical support for clarifying such mutual dependency.

\section{Methodology}

In order to understand the causal relationship between the TCC and GCC-based elites as well as the contribution of the TCC in this significant node of the global economy, this inquiry applies the process tracing and historical explanation methods. This methodology links the history of the formation and expansion of the GCC to changes within global capitalism that coincide with a growth of a transnational capitalist class. Through a detailed empirical analysis, this study exams the extent to which the interests of the political and economic elites within the GCC intersect with the interests of the transnational capitalist class. In order to provide support for this assertion, it is necessary to find evidence that the transnational elites within the GCC are interconnected with the profit-making activities of the TCC, and that the TCC depends on the GCC for a significant flow of financial and/or productive profits and investment activities. It may well be the case that the GCC is more responsive to particular sectors of transnational capital and less responsive to others. If that is the case, or if the GCC is at times completely disconnected from the interests of the TCC, that should also be revealed in this historical narrative. In order to investigate the extent of the relationship between the GCC and the TCC, this study will use the process-tracing method as unearthed by Alexander George and Timothy Mckeown (1985). Briefly, the method investigates the causal relationships that are contextualized within case analysis. With process-tracing and historical explanations, the proposition is often tested based on "relevant, verifiable casual stories resting in differing 
chains of cause-effect relations whose efficiency can be demonstrated independently of those stories" (Tilly, 1997, P.48). Accordingly, as David Laitin points out, the processtracing method attempts to combine statistical explanations and historical narratives. In other words, historical narratives are to "address the questions of process," while the statistical part "addresses questions of propensities" (George and Bennett, 2005, P. 205).

This method will provide a strong analysis for the propositions presented for two primary reasons. First, the process-tracing method is useful for analyzing "macrohistorical economic phenomena." In this dissertation, the case study (GCC) is being analyzed in terms of certain domestic, regional, and international historical processes. Second, as it is addressed in the case-study section, the large body of the literature on GCC suffers from a lack of careful attention to the significant relationship between TCC and GCC-based elites, who indeed determine important social and political situations. I will use some current scholarly work on Middle Eastern studies, but by and large, this dissertation takes a different approach in analyzing its case study. According to Alexander George and Andrew Bennett; "process tracing is particularly useful for obtaining an explanation for deviant cases, those that have outcomes not predicted or explained adequately by existing theories" (George and Bennett, 2005, P. 215).

This method offers a valuable approach for tracing the consistency of the influence of the transnational capitalist class within different economic modes of the global economy. In particular, as it is described above, the struggle and agenda of transnational elites has been evolving. In this sub-region, the evolution of concerns started in a strategic location and moved toward assuring policies to provide uninterrupted access to oil. It still continues with new interests in the financial activities that revolve around secure cycles of 
petrodollars. In fact, such evolution is based on the evolution of the transnational capitalist class' struggles on the global level. Accordingly, such historical phenomena could be explained by historicism and historical explanations. However, in order to fully understand the dynamic of such contexts, I aim to explore key causal relationships between different actors/factors that are contextualized in the history of the political economy of GCC (for instance using certain socioeconomic parameters and the evolution of trade agreements). To do so, the process-tracing method is required along with historical explanations. To avoid ambiguity, throughout the following section I will discuss the process-tracing method as it will be applied in this dissertation.

According to Alexander George and Andrew Bennett there are a variety of processtracing methods. One way to use process tracing is in an "atheoretical" manner or using it as a tactic to provide a chronic account for a "detailed narrative." However, the possible concluding remarks could provide promising grounds for an emerging theory or the development of a theory. The other way to use the method is to utilize "analytical causal explanations" within a theoretical framework. In this way, a theoretical framework is the starting point of research inquiry. As another use of process-tracing method, some researches apply the method for a more general explanation to move up the "ladder of abstraction" (George and Bennett, 2005, P. 210-211).

This dissertation is theory-oriented and does not use narratives as a starting point. Peter Hall pays attention to the significance of "theory-oriented process-tracing." Hall's proposition of process-tracing emphasizes providing a more accurate explanation when it is testing theories. In other words, the process-tracing method could provide a framework in which theories could fit into the world where we have a variety of interactions and 
effects. If the analyses show inconsistencies in the theoretical framework, the theoretical framework will be modified or/and developed. As a result, I do not intend to test a theory. Rather, I attempt to develop an approach.

The process-tracing method tries to "identify the intervening causal process - the causal chain and causal mechanism - between an independent variable (or variables) and the outcome of the dependent variable" (George and Bennett, 2005, P. 206). In order to analyze the economic behavior and influence of the TCC in the GCC states as well as the position of this sub-region and its elites in the global economy, this dissertation investigates such contexts through the interaction between sets of variables that are shown in figure 1.

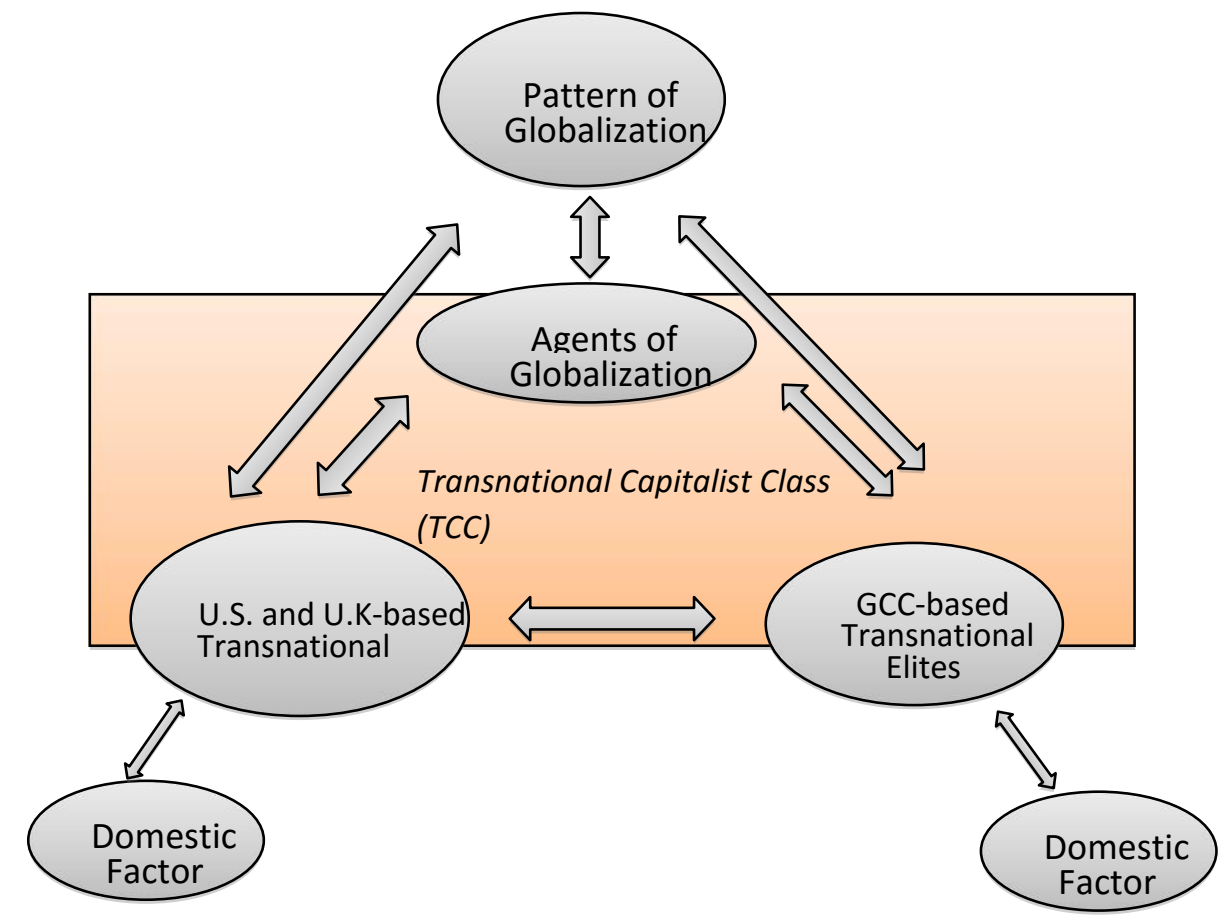

Figure1: Casual Interacting Variables

By applying the above model in this dissertation, I intend to elucidate the mutual dependency between GCC-based elites and the TCC. This dependency has been largely 
ignored by scholars who are working on the Middle East. Accordingly, the far-reaching consequence of transnational elites in the GCC, and sequentially the implications of the current characteristics of the GCC for the global economy, are investigated through the interactions between the above variables, including the pattern of globalization (mainly, financialization of production), agents of globalization (both state and non-state actors), GCC, U.S. and U.K-based transnational elites (who played an important historical role in the GCC and are significant part of the TCC), and domestic factors in GCC states (such as labor politics and trade strategies of each state), as well as domestic historical facts in the United States and United Kingdom (mainly those that are related to policies regarding petrodollars). The above model will be fully clarified in the last chapter.

\section{Data and Sources}

In order to explicate the facts and process systematically, this dissertation will use certain sources and data for its statistical procedures. Foremost, it uses governmental resources such as United States Trade Representative (USTR) archives, mainly for analyzing trade agreements. On the other hand, this study will use international organizations' resources such as those that are provided by IMF, WTO, and World Bank. The other resources are domestic resources of GCC countries, such as "Gulf Center of Development Policies." Finally, this study may use some data resources that are available in articles and books.

\section{Case Study}

This dissertation focuses on the GCC in order to study the phenomenon of transnational elites because the Persian Gulf sub-region appears to be among the most important sub-regions in terms of the world's economy, finance, geopolitics and energy. 
As it will be further discussed, the sub-region poses some challenges to certain mainstream understandings of Middle Eastern studies. Therefore, it is important to clarify the analytical distinction between liberalism and historical-structuralism.

In short, advocates of globalization argue that free trade has a positive correlation with national and regional development and growth. In the same vein, Bhagwati adds that free trade, which leads to the integration of the participating countries into the global economy, provides more domestic freedom as well. Bhagwati's pro-globalization approach follows closely the classical liberal faith in the efficiency of the market system. He writes: "[i]t is precisely the growing awareness that globalization creates a web of relationships that introduce such complexity, and hence prudence and pause in the policy choices of nation-states that has led to the charges that globalization and democracy are at odds" (Bhagwati, 2007, P. 8).

Liberals argue that the deepening integration of states within global capitalism has the potential to make these states and societies more free. This school of thought also assumes that the capitalist marketplace is organized and developed through the individual decisions of market players, instead of being constructed politically and economically by powerful class forces that rely on both economic consolidation and political coercion to secure their power. Therefore, the key argument of liberals is that the problem with the Middle Eastern states is they are not fully integrated into the capitalist world system, but, instead, are governed too much by political authorities and not enough by the market.

However, the liberal scholars could not provide an accurate explanation of the maintenance of this status quo in the GCC. In other words, the market economy has been dramatically developing and expanding in these states while they have not experienced any 
significant changes in term of authoritarian trends of their states. More importantly, and as this study will argue, such maintenance is highly protected by liberal democracies in the West. In fact, the most significant factor, as historical structuralism addresses, is the role played by influential classes. In other words, the main issue is that the protection of the interest of the TCC is dependent on GCC-based elites and authoritarian development in this sub-region.

Accordingly, in contrast to liberal claims, in the GCC little evidence seems to exist showing that a greater level of economic integration has led to greater domestic freedom. In other words, political coercion in the Middle East is central to global capitalist profits and the social structure of accumulation in this phase of global capitalism in particular. Arguably, the TCC has grown more dependent on authoritarian institutions in the Middle East over time. Thus, economic liberalization does not equate to political liberalization but instead sometimes requires it's opposite (i.e. authoritarian structures that provide maximum space for transnational class interests to profit). Accordingly, greater integration of the Persian Gulf Arab states into the global economy and the removal of trade barriers have solidified the position of the regional transnational elites, which in turn has stabilized authoritarian regimes in the sub-region.

The issue of stability of the sub-region's monarchies deserves closer attention. As mentioned before, global capital has increasingly viewed the maintenance of the status quo in the Persian Gulf sub-region as a primary concern. In the words of Adam Hanieh, a key strategy of global capital has been "prioritizing the status quo and seeking to block any possibility of regime change" (Hanieh, 2011, P. 176). This is not surprising given the conventionally accepted notion that capital often seeks security, without much concern 
about what the source of that security may be. The more-than-accidental relationship between the authoritarian status quo in the Persian Gulf sub-region and the highly globalized economic systems of this sub-region is a serious challenge to the neo-liberal account of global dynamics. Table 1 below helps to illustrate the seemingly paradoxical situation in the Persian Gulf sub-region, if one is to accept the neo- liberal perspective.

\begin{tabular}{|c|c|c|c|c|c|c|}
\hline Country & $\begin{array}{c}\text { Economic } \\
\text { Freedom } \\
\text { Index }\end{array}$ & Ranking & PR & CL & Status & $\begin{array}{c}\text { Freedom } \\
\text { Rating }\end{array}$ \\
\hline Oman & 68.1 & 45 & 6 & 5 & NF & 5.5 \\
\hline Qatar & 71.3 & 27 & 6 & 5 & NF & 5.5 \\
\hline $\begin{array}{c}\text { Saudi } \\
\text { Arabia }\end{array}$ & 60.6 & 82 & 7 & 7 & NF & 7 \\
\hline Kuwait & 63.1 & 66 & 5 & 5 & PF & 5 \\
\hline UAE & 71.1 & 28 & 6 & 6 & NF & 6 \\
\hline Bahrain & 75.5 & 12 & 6 & 6 & NF & 6 \\
\hline GCC & 68.28 & & & & & 5.8 \\
\hline
\end{tabular}

Table 1: Freedom Status of GCC states

(PR: Political Right, CL: Civil Liberty, NF: Not Free, PF: Partly FREE) Source: Freedom House and the Heritage Foundation, 2013

In the Freedom House categorization, when a freedom rating for a country is between 5.5 to 7.0, the country is considered as "Not Free." According to Table 1, the Persian Gulf Arab states are among the top 24 percent of "Not Free" countries. On the other hand, with the average Economic Freedom Index of 68.28, these countries are among the top 24 percent of the world's free economies. It may be added that Polity IV Project 
also categorizes the sub-region's six monarchies as autocracies (rather than constitutional monarchies).

As for the issue of stability, Table 2 provides the Failed State Index for all the countries within the GCC. The Failed State Index is often relied on as a relatively accurate indicator of the level of stability in various countries. In 2012, this Index was measured for 178 countries "based on their levels of stability and the pressures they face" (The Fund for Peace, 2012, P. 3).

\begin{tabular}{|c|c|c|}
\hline Country & $\begin{array}{c}\text { Failed State } \\
\text { Index }\end{array}$ & Ranking \\
\hline Oman & 51.7 & 137 \\
\hline Qatar & 48 & 142 \\
\hline Saudi Arabia & 73.4 & 100 \\
\hline Kuwait & 58.8 & 128 \\
\hline UAE & 48.9 & 140 \\
\hline Bahrain & 62.2 & 125 \\
\hline GCC & 57.16 & \\
\hline
\end{tabular}

Table 2: Level of Stability in GCC states

Source: www.failedstatesindex.org, 2012

According to Table 2, the Persian Gulf Arab states are among the top 27 percent of the most stable countries in the world (where the lower rank means more stability). The high level of stability holds true today, even despite the recent "Arab spring," which has 
shaken the sociopolitical structure in the rest of the Arab world. To better grasp the significance of stability within the GCC, it is useful to consider the immediate neighbors of the GCC members and how they score when it comes to stability. Table 3 provides the figures based on the same Failed State Index. According to these numbers, the rest of the Middle East is among the 19 percent most unstable countries in the world.

\begin{tabular}{|c|c|c|}
\hline Country & $\begin{array}{c}\text { Failed State } \\
\text { Index }\end{array}$ & Ranking \\
\hline Egypt & 90.4 & 31 \\
\hline Iran & 89.6 & 34 \\
\hline Cyprus & 66.8 & 115 \\
\hline Iraq & 104.3 & 9 \\
\hline Israel/West Bank & 82.2 & 61 \\
\hline Jordan & 74.8 & 90 \\
\hline Lebanon & 85.8 & 45 \\
\hline Syria & 94.5 & 23 \\
\hline Turkey & 76.6 & 85 \\
\hline Yemen & 104.8 & 8 \\
\hline Average & 89.98 & \\
\hline
\end{tabular}

Table 3: The Level of Stability in the rest of Middle Eastern States Source: www.failedstatesindex.org, 2012

Arguably, one of the outstanding questions concerning the nature of these authoritarian regimes is how they have managed to juxtapose a traditional ruling system with certain forces of modernization that are often considered to be causes of instability in non-democratic regimes. Many authors and commentators have correctly paid attention to 
the domestic factors leading to the considerable level of stability in these six countries. Yet, the picture remains incomplete unless one takes into account the international factors, which are often channeled through the transnational elites.

Russell Lucas observes that; "[a]mong Middle Eastern monarchies, regime-led state formation and nation building have produced a flexible form of rule that has survived the challenges of rapid development and international conflicts" (Lucas, 2004, P. 103). On the other hand, some scholars have pointed to the nature and composition of oppositions in these monarchies in order to explain their stability. For instance Gurdun $\mathrm{Kr} "$ amer argues that in Saudi Arabia, Jordan, and Morocco, the oppositions have had goals other than the overthrowing of the system - or so-called regime change. As mentioned before, however, domestic political structures are not the only factors at play here. A key argument of the dissertation is that domestic politics of the GCC countries should not be viewed as deterministic factors - as it may be suggested in Innenpolitik theories. In other words, the domestic level of analysis falls short of offering a robust analysis of this sub-region.

It may also be noted that, in the GCC monarchies, domestic politics have often been shaped in important and enduring ways by external factors. These factors have led to the creation of the current Social Structure of Accumulation (SSA). Thus, the so-called domestic situation is deeply colored by the larger more global context. This domesticinternational dynamic for the GCC countries goes back decades, and arguably in the case of a number of GCC members, to the time they became independent states. In 1964, for instance, William Luce pointed out that the Persian Gulf "was inherently a political vacuum that must be filled by British, and perhaps U.S., power in order to remain stable" (Fain, 2008, P. 152). 
This is echoed by F. Gregory Gause, who argues that "the success and failure of monarchy in the Arabian Peninsula in the twentieth century had more to do with the position of Arabian countries in the regional security picture and the international political economy than with their particular domestic characteristics" (Lucas, 2004, P. 110). This dissertation agrees with these propositions, and builds its analysis, first and foremost, based on the position of these six countries in the international political economy order based on the mutual dependency of GCC-based elites and the transnational capitalist class. Among many factors that may be used for this study in international political economy, this dissertation focuses on the TCC in the GCC for two reasons. First, the role of TCC in general and the GCC transnational elites in particular is relatively understudied in the field of IPE. Second, for the reasons that will be further elaborated in the course of this study, the transnational elites of the Middle East play a disproportionally more important role in shaping regional and domestic politics in their countries compared to many other regions of the world.

\section{Is GCC an Indigenous Institution?}

The [Persian] Gulf Cooperation Council is not an indigenous institution, resulting from the organic forces at works in the sub-region. One way to analyze the creation of and the ensuing dynamics within the GCC is to view it as a regional bloc. In fact, the GCC is

sometimes described as a trading bloc. Some scholarly works emphasize the domestic/indigenous contexts in the creation of regional blocs. However, in the case of the GCC, the domestic dynamics have not been as significant as they may be in other regional integration. In other words, the creation of the GCC is more rooted in the position of this 
sub-region within the global order of capital rather than the domestic arrangement of scale economies and production-sharing networks.

In fact, it is important to explore the intersection of domestic class actors and transnational class actors in the creation and expansion of the GCC. For instance, GCC is a response to the interests pursued by regional class actors, but those actors are increasingly integrated into global capitalist relationships. This would allow an investigation from a fresh angle of an international body that, in the words of Hanieh, has a position of "centrality to the hierarchies of the world market" and manifests par excellence the "two immanent tendencies of capitalism - the internationalization and financialization of capital" (Hanieh, 2011, P.177). Accordingly this internationalization and financialization is highly promoted and protected by the institutional, political, and economic connections between transnational elites of the Middle East and the TCC. The regional integration of the GCC states and the international integration of the GCC are part of the internationalization of GCC capital.

The internationalization of capital in the GCC is rooted in the process of how the transnational elites of GCC constitute both an extension of a regional class grouping and a transnational class faction. Accordingly, one method to examine the GCC's transnational elites (who significantly but not completely overlap with the sub-region's ruling classes) is to trace the institutional facts. For instance, the active role of these authoritarian states in several international institutions could offer a clue to the ties between the GCC's transnational elites, on the one hand, and the global TCC, on the other. In terms of international trade, all the GCC members are the members of the World Trade Organization (with Qatar being the host for the current Doha Round of negotiations) as well as some 
other free trade organizations and agreements. For instance, Saudi Arabia is also a member of the International Chamber of Commerce (ICC), International Organization of Standardization (IOS), and World Customs Organization (WCO). On the other hand, the conclusion of a "Framework Agreement for Trade, Economic, and Technical Cooperation," along with bilateral agreements between the Persian Gulf Arab states and the United States, indicate a high level of interconnectedness between these economies and U.S.-based transnational elites. Moreover, the WTO membership of these countries has facilitated a movement towards the Middle East Free Trade Area Initiative (MEFTA).

In terms of military institutions, four members of the Gulf Cooperation Council Bahrain, Kuwait, Qatar, and the United Arab Emirates - are participants in NATO's Istanbul Cooperation Initiative. This military relationship in particular introduces a new strategic linkage between the GCC's transnational elites and the global capital, a linkage that goes well beyond pure business interests. In his book, Arab Spring, Libyan Winter, Vijay Parshad discusses this military relationship, and he coins the term the "Arab NATO" (Prashad, 2012, P. 181). Evidence of this qualitatively different angle of collaboration may be found in the extensive U.S. military presence in Qatar and in the words of Secretary Chuck Hegel, who recently promised in Bahrain that the Pentagon "will better integrate with GCC members to enhance missile defense capabilities in the region" (Defense News, 2013).

However, it is important to remember that what is at stake here is not only the military or security aspects of the Arab NATO, but the economic relationship facilitated, and protected, under the umbrella of this military connection. Such economic relationship is determined by the crucial position of GCC-based transnational elites in regards to the 
transnational capitalist class. In fact, one key element of this dissertation study is to further investigate the economic rationale of selling very expensive military equipment on a large scale to the GCC states from the perspective of the region's transnational elites, as well as that of the global capital. The military purchases, second only to oil and energy transactions, appear to be a key component of the significant business activities between the GCC capitalist class on the one hand, and the global TCC on the other. According to Doug Stokes and Sam Raphael, U.S. military intervention is a significant angle of American "grand strategy." This military intervention could be indirectly projected, such as in the case of the GCC militarization. In fact, the United States' role as a hegemon requires secure and reliable access to strategic resources, especially to oil resources. As will be shown in this dissertation, petrodollars play an important role as the new strategic resource. In fact, GCC markets operate as authoritarian vehicles for global market accumulation, not the same thing as "liberal markets," but useful to liberal markets and globalization due to their authoritarian policing of market structures.

According to Secretary Hegel, the United States has provided its "most advanced fighter aircraft throughout the region" (Defense News, 2013). In other words, some of the most advanced military technologies in the world have been given to these six countries. Yet these military transactions have long-term non-military aspects as well. In particular, due to the weakness of such non-military/non-authoritarian forms of power in the Persian Gulf Arab states as education and national cohesion, the military ties render the GCC countries dependent on continuous external and technical assistance by Western powers. This dynamic has furthered the interdependence between the ruling elites in the GCC and the United States. 
In summary, while this dissertation is clear that scholars should not neglect domestic factors within Persian Gulf Arab states, it focuses on non-domestic elements as the more influential, and yet under-studied, aspects of the regional politics in this part of the world. Furthermore, this dissertation contends that studying the sub-region's transnational elites provides a balanced platform to analyze the international factors that influence the behavior and composition of the TCC as well.

\section{The Structure of the Dissertation}

This dissertation will include five chapters. This introductory chapter introduces the theoretical framework as well as the central notions and propositions of the study. The second chapter discusses the concept of GCC transnational elite within the new phase of globalization in order to provide the groundwork for the third and the fourth chapters. The differences between the former stage of global capitalism and the new form is discussed in more detail in the context of the GCC transnational elite. Although there are important similarities between these stages, the differences are crucial for a better understanding of the transnational elites. In addition, the second chapter discusses the historical processes that led to the current position of the GCC sub-region petrodollars in the global market.

The third chapter focuses on the transnational ties between GCC elites and the TCC, in particular the role played by the U.S. and the U.K-based transnational elites and their interactions with their counterparts in the GCC, institutionally and historically. As will be shown in the data, the United States and United Kingdom have been and remain the most important partners with the GCC's transnational elites. The fourth chapter focuses on the GCC in the context of international political economy and a number of domestic factors, including labor politics and the domestic implications of foreign direct investments. 
Following a discussion of the GCC's history in the context of globalization studies, this chapter offers a broad picture of the GCC's transnational elites and considers their backgrounds and their use of power, which is an important root causes behind many aspects of the economic and geopolitical status quo in the Persian Gulf sub-region.

Due to the geostrategic importance of the Persian Gulf, the state of the status quo in this sub-region has direct impact on the larger Middle East and indirect impact on the global production networks. Two factors are important in this regard. The first is the significant role played by the region's petrodollars controlled by the GCC's transnational elite in the Western financial markets. The second factor is the visible participation of the GCC members in a number of influential global institutions, mainly in the area of finance and trade, but increasingly in military institutions as well. Chapter Four considers the militarization of GCC transnational space and some of these broader global implications of the policies and priorities of the GCC's transnational elite. Chapter Five concludes the dissertation with a brief discussion of how the GCC national economies have been integrating into the global economy through the GCC transnational elites. Using the findings of each chapter, it identifies the main implications of this economic integration.

While one should not disregard domestic factors within Persian Gulf Arab states, this study focuses on non-domestic elements as the more influential, and yet under- studied aspect of the regional politics in this part of the world. It further maintains that studying the sub-region's transnational elites provides a balanced platform for analyzing both the international factors and the more significant domestic factors that shape the economic and political developments in the region. 


\section{References:}

1. Anderson, L. (2000). Dynasts and nationalists: why monarchies survive. Middle East Monarchies. The Challenge of Modernity, Boulder: Lynne Rienner, 53-70.

2. Bhagwati, J. (2007). In defense of globalization: With a new afterword. Oxford University Press.

3. Buzan, B., \& Gonzalez-Pelaez, A. (2009). International society and the Middle East: English school theory at the regional level. Basingstoke: Palgrave Macmillan.

4. Buzan, B., \&Wæver, O. (2003). Regions and powers: The structure of international security. Cambridge: Cambridge University Press.

5. Chase, K. A. (2005). Trading blocs: States, firms, and regions in the world economy. University of Michigan Press.

6. Cox, Ronald. W. (2012). Corporate power and globalization in US foreign policy. London: Routledge.

7. Cox, Robert. W. (1996). Approaches to world order (No. 40). Cambridge University Press.

8. Cox, Robert. W. (1993). Gramsci, hegemony and international relations: an essay in method. Cambridge Studies in International Relations, 26, 49-49.

9. Cox, Robert. W. (1981). Social forces, states and world orders: beyond international relations theory. Millennium: journal of international studies, 10(2), 126-155.

10. Fain, W. T. (2008). American ascendance and British retreat in the Persian Gulf region. Palgrave Macmillan.

11. Gause, F. G. (2011). Saudi Arabia in the New Middle East (No. 63). Council on Foreign Relations.

12. Gause, F. G. (2000). The persistence of monarchy in the Arabian peninsula: a comparative analysis. Middle East Monarchies: The Challenge of Modernity. Boulder: Lynne Rienner.

13. George, A. L., \& Bennett, A. (2005). Case studies and theory development in the social sciences. Mit Press.

14. Hall, P. A. (2003). Aligning ontology and methodology in comparative research. Comparative historical analysis in the social sciences, 374. 
15. Hanieh, A. (2011). Finance, oil and the Arab uprisings: the global crisis and the Gulf States. Socialist Register, 48(48).

16. Hanieh, A. (2011). Capitalism and class in the Gulf Arab states. New York: Palgrave Macmillan.

17. Harvey, D. (2005). A brief history of neoliberalism. Oxford University Press.

18. Kotz, D. M., \& McDonough, T. (2010). Global neoliberalism and the contemporary social structure of accumulation. Contemporary capitalism and its crises: Social structure of accumulation theory for the 21st century, 93-120.

19. Krämer, G. (2000). Good Counsel to the King: The Islamist Opposition in Saudi Arabia, Jordan, and Morocco. Middle East Monarchies-the Challenge of Modernity, Boulder: Lynne Rienner, 257-287.

20. Lucas, R. E. (2004). Monarchical authoritarianism: survival and political liberalization in a Middle Eastern regime type. International Journal of Middle East Studies, 36(01), 103-119.

21. Prashad, V. (2012). Arab Spring, Libyan Winter. AK Press.

22. Policy, F. (2012). FSI 2012| the Fund for Peace. The Fund for Peace.

23. Robinson, W. I. (2003). Transnational conflicts: Central America, social change and globalization. Verso.

24. Robinson, W. I. (2005). Gramsci and Globalisation: From Nation-State to Transnational Hegemony. Critical review of international social and political philosophy, 8(4), 559-574.

25. Robinson, W. I. (2004). A theory of global capitalism: Production, class, and state in a transnational world. JHU Press.

26. Robinson, W. I., \& Harris, J. (2000). Towards a global ruling class? Globalization and the transnational capitalist class. Science \& Society, 11-54.

27. Soederberg, S. (2004). The politics of the new international financial architecture: Re imposing neoliberal domination in the global south. Zed Books.

28. Tilly, Charles. "Means and ends of comparison in macrosociology." Comparative Social Research 16 (1997): 43-54.

29. Wade, R. (2006). Choking the south. New Left Review, 38, 115. 
30. Wade, R. H. (2002). US hegemony and the World Bank: the fight over people and ideas. Review of international political economy, 9(2), 215-243.

\section{Other Sources:}

1. Office of the United States Trade Representative, 09/27/2012, "United States Trade Representative Ron Kirk Announces Agreement with Gulf Cooperation Council to Strengthen Economic Ties, Expand Trade and Investment Relationship", Available Here: http://www.ustr.gov/about-us/press-office/press-releases/2012/september/ustrkirk- announces-agreement-gcc.

2. Office of the United States Trade Representative, "Middle East Free Trade Area Initiative (MEFTA), Available Here: http://www.ustr.gov/trade-agreements/otherinitiatives/middle-east-free-trade-area-initiative-mefta

3. Defense News, Dec. 7, 2013, "Hegel: US sell Weapons to GCC States as a Block", Available. Here:

http://www.defensenews.com/article/20131207/DEFREG04/312070009/Hagel-USSell- Weapons-GCC-States-Block Charter of the Gulf Cooperation Council (GCC), 25/May/1981

4. http://www.systemicpeace.org/polity/polity4.htm

5. http://www.freedomhouse.org/

6. http://ffp.statesindex.org/

7. http://www.heritage.org/ 


\section{CHAPTER II}

\section{THE POLITICAL ECONOMY OF A TRANSNATIONAL ELITE IN THE GCC}

\section{Introduction}

During the earliest stages of the GCC's recent economic growth consultant and journalist Michael Field traveled to the Arabian Peninsula. He described his experiences in his book, The Merchants, The Big Business Families of Saudi Arabia and the Gulf States

(1984). A keen observer of socioeconomic structures, Field wrote, "[T]he merchant families are part of the Arabian establishment. They dominate Arabian commercial life and they have been responsible for as many economic innovations as the governments. They have established most of the new Arabian investment banks, light industries and high technology service companies. In the Gulf States, which have a tradition as trading communities, the merchants are the most valued constituents of the ruling families; their senior members are consulted on most important domestic political issues. In both Saudi Arabia and the Gulf states the merchants serve the ruling families in government" (Field, 1984, P. 11).

In this chapter, I provide an overview of the dynamics of capital accumulation within the current economic structure of the GCC. One integral part of these dynamics has been the evolution of the relationship between the GCC states and the Western powers, mainly the United States and the United Kingdom. Therefore, I use the first section of this chapter to examine the strategies adopted by Western powers for dealing with the GCC states and the emerging GCC transnational elites, and some of the reasons and interests behind these strategies. The second component of this analysis deals with the domestic setting of the GCC states in order to explore the other side of the structure 
of capital accumulation, as well as the role and characteristics of the GCC transnational elites.

\section{The Historical Evolution}

Major world powers have long identified the GCC as an important geostrategic location. Great powers have also sought to carve out new markets for themselves, as well as to control important trade and military routes throughout this region. For example, according to L.G. Potter, "the principal impetus for initial British entry into the Gulf was a combination of a search for markets and an effort to deny European rivals supremacy in the region" (Potter, 2009, P. 278). In fact, the Persian Gulf and its Arab states have long been among the most significant geostrategic regions for great powers. Beginning with the early sixteenth century, for around two centuries, the Persian Gulf was part of "Portugal's Asian Empire" (Potter, 2009, P. 278). The geostrategic appeal of the region along with the economic interests in finding new markets attracted the Dutch and the Ottomans as well. More recently, the context of the great power competition in the Middle East has changed from a colonial to a post-colonial one. Even more recently, the post-colonial intrusion of great powers into the region has been shaped by a globalization of the transnational capital, in which, "a key aspect in the globalization is transnational class formation" (Robinson, 2001, P. 533).

Following the demise of classical imperialism and during the post-colonial era the legacy of imperialism has reemerged in various informal economic activities. A key feature of these economic activities is that they "are not regulated, monitored or controlled directly or indirectly by the states" (Routh, 2011, P. 211). Such informal economic activities, partly facilitated by a series of international institutions such as the 
International Monetary Fund (IMF) and the World Trade Organization (WTO), have accelerated new patterns of structural involvements of the great powers in other regions' affairs. In the past few decades arguably the most noticeable economic structure that “informal imperialism" has manifested in its various political, social and economic aspects has been the "transnational space." Under the current mainstream process of capitalization, the transnational space has appeared as the most preferential climate for transnational capital. For example, W.I. Robinson regards it to be "[t]he hegemonic fraction of capital in a world scale" (Robinson, 2003, P. 39). This space also lends itself quite well to the informal economic activities, especially those that rely on cheap labor and raw materials.

In the Persian Gulf, Great Britain was the first great power that recognized the usefulness of local elites for advancing its imperialist goals in the region. This is one of the reasons that decades after the apparent end of the British colonial presence in the region, that country still exerts a strong influence on almost all of the smaller Persian Gulf Arab states. From the earliest stages of British imperialism, the United Kingdom designed the structure of its relationship with the "protected" states of the GCC in such a way that informal imperialism was embedded in the GCC elites:

"[w]hen Britain thought it necessary to replace a sitting shaikh, it preferred to work behind the scenes and within the ruling family. In 1923, Britain engineered the abdication of Shaikh Isa b. Ali Al Khalifa in Bahrain and his replacement by his son Hamad b. Isa in order to institute what it believed to be long-overdue reforms in the country. In 1965, British officials encouraged members of the ruling Qawasim family in Sharjah to depose Shaikh Saqr b. Sultan, a thorn in the British side because of his admiration for pan-Arab nationalism and ties to Gamal 
Abdel Nasser and the Arab League. In 1966, Britain prodded Shaikh Zayid b. Sultan Al Nahyan to remove his long-serving brother Shakh who was clearly unsuitable to govern an oil-era state. In 1970, Britain encouraged young Sayyid Qabus b. Sa'id to overthrow his father as Sultan of Oman. (Potter, P. 283)

In the early 1970s, after Great Britain reduced its military and security engagement in the Persian Gulf, the United States began to fill the vacuum by relying on surrogates (or "key allies") to ensure that oil would be delivered to the West without interruption. Iran and, to a lesser extent, Saudi Arabia were the key U.S. regional allies during the 1970s. However, the Iranian Revolution of 1979 abruptly terminated Iran's partnership with America, which then relied more heavily on Saudi Arabia to advance its oil interests (Potter, 2008, P. 295). Following the Iranian Revolution, in a major strategic change for both the United States and the region, President Jimmy Carter issued the Carter Doctrine, in which, for the first-time, the U.S. announced that it would use its own armed forces to protect the "global" (i.e. the West's) access to oil, instead of relying on the allies in the region. According to Carter, "an attempt by any outside force to gain control of the Persian Gulf region will be regarded as an assault on the vital interests of the United States of America, and such an assault will be repelled by any means necessary, including military force" (Carter, P. 27). The Carter Doctrine paved the way for the contemporary mode of American militarism in the region; and due to its connection to oil from the outset, the Doctrine is closely tied to the deeper integration of the region into the global economy. Therefore, the Carter Doctrine can be viewed as a dividing line that marks the deeper integration of the region into the globalized structure of transnational production. This integration was consistent with the familiar pattern in oil-rich regions in the global south, 
where, according to D. and Raphael S. Stokes, "transnationalization is bolstered by militarization" (Stokes, 2010, P. 3). Not surprisingly, the combination of American strategy and the GCC's acquiescence with it has led to the repeated use of force and the strong presence of repressive state apparatus in the GCC region.

Following the implementation of the Carter Doctrine, the level of integration between the West and the Persian Gulf region - with the important exception of Iran - has increased dramatically. Subsequently, the nature of the integration has shifted from international ties to transnational ties. In other words, there has been a deepening of military, economic and social ties between the two sides that took place before the end of the Cold War. Even though the end of the Cold War has often been seen as a more dramatic transformation toward further transnationalization, the GCC region was already well advanced in transnationalization when the Soviet Union collapsed. However, the transformation intensified after the collapse, partly due to the very fact that the Soviet Union no longer existed in the 1990s; therefore, it no longer stood as a barrier to the transformation. On the other hand, after the long-term suppression of the leftist and nationalist movements in the Persian Gulf, no significant domestic voices were in place to call for regulation of capital so that local socio-economic structures could emerge. Western military powers had supported the suppression of anti-capitalist voices in the region long before even the Iranian Revolution. In fact, as an element of the Carter Doctrine, the Rapid Development Force (RDF) was formed in order to protect the U.S. interests in the region and to fight against any threats to those interests. The most notable threats identified and targeted by RDF were the leftist and nationalist movements that had the potential to bring about a regime change (Stokes, 2010, P. 91). 
To counter such movements, generous military support was offered to the ruling elites. For instance, Saudi Arabia, the most powerful GCC state, has remained as "one of the least free countries in the world, with political and economic power held by a very small ruling elite. Because this rule largely rests upon American military support and such support is contingent upon the free flow of oil, U.S. and Saudi interests have remained deeply entwined throughout the postwar era" (Stokes, 2010, P. 88).

Throughout the process of transnationalization of capital an emerging tendency appears to be the creation of local elites who have fewer and fewer ties with domestic institutions. P. Mair believes that, in this context, the ruling legitimacy will gradually decline while the "citizenry are becoming effectively non-sovereign" (Mair, 2006, P. 25). It is, in fact, the nature of transnational globalization that creates non-sovereign citizenries who are subjugated to transnational rulers. Thus, it is not surprising that the resulting delegitimized elites need to be protected by military force, given potential socioeconomic unrest that ensues within such an unstable state-society relationship. As a result of this scheme, the United States continues "to put significant effort into protecting the region's oil infrastructure and bolstering the capacities of pro-U.S. elites to stabilize their respective territories and repress challenges to U.S. interests" (Stokes, 2010, P. 100). To summarize, as a consequence of both deepening economic integration and geopolitical calculations, the role of the Persian Gulf - both as a region and as a collection of states - remains crucial today for shaping the global balance of power within capitalism. Currently, the decisions made by the GCC states help shape the nature of global foreign trade, investment, and politics. For instance, the rivalry between the United States and China over acquiring more and more economic benefits from the region has become a key component within the 
overall economic and political dynamics of the region, and the positions that individual GCC states take in relation to this rivalry influence not only regional but also global economic, political, and, potentially, even military developments.

There are two dimensions to the way decisions made by the GCC states affect global trade, investment, and politics. First is the GCC states' own economic decisions and behavior; second is the international economic context of those decisions and behaviors. The following section discusses how the GCC states' economic behavior, heavily influenced by the transnational capitalist principles, has evolved toward transnational economic activities.

\section{The Emergence of a GCC Transnational Elite}

Historically, the capitalist economic structure of the GCC states has been developed through the particular transnational ties between the GCC and the rest of the world economy. In order to investigate the nature and impact of transnational economic interactions between Western powers and the GCC states and the evolution of these interactions, it is necessary to consider what, exactly, the institution of "state" entails within the GCC countries. In fact, the influences of old and well-established commercial merchant families have been quite significant in the region's political hierarchies from the before the foundation of modern states in the Arabian Peninsula. In terms of the historical structure and political dynamics of the societies, Lawrence Potter observes that the "... tribes were the key to forming modern states in the Arabian Peninsula, and the

dynasties presently ruling there are all of tribal origin" (Potter, 2009, P. 2). These tribes were originated based on family and blood ties. The resulting political structure has been what M. Field observed some three decades ago about the significant role of merchants as 
important actors in ruling "families." As a result, important families and influential wealthy individuals within these families have become the most significant actors in the interactions between the West and the GCC states. Many of these families have been both merchants and rulers at the same time. For the most part, the merchant-ruler combination still applies to most GCC ruling families today.

On the other hand, unlike many other monarchies where the ruling family came to power by controlling a pre-existing state, the GCC ruling families themselves created the very institutions that govern the modern state over which they reign. Accordingly, there is a quite blurred line between the institution of "royal family" and that of "state" in the GCC countries. Moreover, the mode of GCC governance appears to create a modern/traditional dichotomy: a modern state with tribal origins. This dichotomy has manifested in numerous ways in the process of capital accumulation. In particular, the dichotomy provides gaps and "breathing spaces" that have facilitated the emergence of the GCC-based transnational elites.

One of the central arguments presented in this thesis is that the roles played by the transnational elites of the GCC are crucial to any analysis of the socio-economic and geopolitical dynamics of this region. The GCC elites, almost all of whom come from wealthy, politically influential families, are by far the most important agents in the political economy of the GCC. During the past few decades they have also become important players in global capital accumulation. The GCC elites are directly connected to transnational economic activities as a "class-in-itself," meaning that these elites are important for facilitating the global accumulation of profits. In other words, in modern times the relationship between the Western powers and the GCC states has been 
contextualized in the development of global capitalism and the current pattern of globalization of transnational capital; the relationship resembles that of intercorporate rather than international - affairs, and it is highly influenced by struggles within the TCC. Moreover, "[g]lobal capitalism is not a collection of "national' economies but the suppression through transnational integration of 'national' economies understood as autonomous entities related through external exchanges to other such entities" (Robinson, 2001, P. 533). However, the GCC transnational elites have penetrated the process of decision making to the extent that the class is politically subordinate to the TCC.

It is common among many scholars who work on the GCC to regard the GCC elites as nationally and/or internationally-oriented actors. It is perhaps true that, at the beginning, the "elites" in the Arabian Peninsula had been internationally oriented. During the past two decades, however, any international characteristic of these elites has dramatically changed towards a transnational orientation. Arguably, what ushered in this new transnational character of the GCC elites was the role of oil and its commercialization in the region.

Natural resources such as oil have existed for a long time in this region; and the ability of the local GCC elites to profit from exploiting them goes back to the time when these elites were international elites. What has happened more recently, however, is that the GCC elites have developed a much more embedded relationship with the global TCC through such arrangements as expanded investment linkages (especially in finance and oil). Therefore, these elites no longer simply function as reliable producers of oil that is sold in the world markets. Instead, the GCC elites are the key piece of an oil production and financial supply chain that renders them partners with Western TCC firms. 
Nevertheless, one of the most significant characteristics of these elites remains the fact that their economic activities have always been, and continue to be, based on the sale of oil.

The emergence of transnational actors in the GCC region is not a phenomenon that happened in isolation from the general process of transnational globalization. Neither has it been separated from the particular development of transnationalization that has taken place in the Persian Gulf. In terms of transnational globalization, it appears necessary to analyze the concept based on transnational practices (TNPs) - practices that different actors, including states, are engaged in throughout the process of globalization. Understanding of the notion of transnational globalization is crucial in analyzing the GCC. Elaborating this conception of globalization, Sklair writes:

"The transnational conception of globalization postulates the existence of a global system. Its basic units of analysis are transnational practices (TNP), practices that cross state boundaries but do not originate with state agencies or actors. Analytically, TNPs operate in three spheres, the economic, the political, and the cultural-ideological. The whole is the global system. While the global system is not synonymous with global capitalism, what the theory sets out to demonstrate is that the dominant forces of global capitalism are the dominant forces in the contemporary global system.” (Sklair, 2000, P. 69)

Increasingly, the GCC economy has been steered toward transnationalization, with the TNPs playing a significant role within this region. TNPs are the "practices that cross state boundaries but do not necessarily originate with state agencies or actors" (Sklair, 1998, P. 2). For structural reasons, TCC interests are tied to TNPs rather than to local economic activities. A significant part of the political economy of the GCC countries is 
based on the economic activities of TNCs, rather than any domestic or national industrial, high-tech or service sections. The direct link between the GCC states and TCC is, therefore, obvious, as it is the members of TCC that control transnational corporations and TNPs. On the other hand, TCC has to exert more and more power on national institutions in order to protect and enhance its role and protect its interests.

The GCC states continue to play a significant role in the process of transnationalization. In particular, an understanding of the notion of a transnational states is necessary in order to properly understand the extent and the nature of TNPs in the GCC. Robinson offers three (interrelated) propositions for the concept of state based on "historical materialist conception of state."

“1) economic globalization has its counterpart in transnational class formation and in the emergence of a transnational state (henceforth, TNS) that has been brought into existence to function as the collective authority for a global ruling class; 2) the nation-state is neither retaining its primacy nor disappearing but becoming transformed and absorbed into this larger structure of a TNS; 3) this emergent TNS institutionalizes a new class relation between global capital and global labor". (Robinson, 2001, P. 158)

The transnationalization that has taken place in the GCC region relies on three historical facts. The first is the presence of enormous oil and gas resources, which in turn have invited a host of transnational corporations to the region and led the politics and economy of the GCC to be shaped, to their very core, by transnational practices. The "transnationalization" has occurred in two (related) directions. First, there are the transnational practices by outside entities in the GCC region, and second, there are the 
transnational practices of the GCC elites in other regions of the world. Meanwhile, as the political economy of the GCC has been increasingly shaped by TNPs, so has its economic culture. Therefore, notions of production, wealth, economic activity, profit, labor and capital, as well as social justice, are understood (or ignored) according to the perspective of TNPs.

The second pertinent historical fact is that religious extremism has become a major source of the legitimization of the ruling families. In the early 1960s, the World Muslim League (WML), and, even most importantly, King Faysal, then-ruler of Saudi Arabia, concluded that nationalism and socialism, along with secularism, were significant threats to Islam. As a result, religion emerged as a significant instrument at the disposal of the state to suppress anti-capitalist voices. Accordingly, the nationalism of the Nasser era gradually gave way to various forms of pan-Islamism (Prashad, 2008, pp. 260-61). Therefore, only conceptualizations of nationalism that included strong elements of religion could legitimize the GCC capitalist classes as they tried to justify their rule over their traditional societies. Religious-based conceptualizations of nationalism could, therefore, remove many domestic obstacles to establishing the capitalist principles that were necessary for global capital accumulation.

The third relevant historical fact is the formation of a new set of class relations. Some four decades ago Fred Holiday predicted the collapse of these authoritarian regimes due to the exploitive economic relations that would trigger high level of dissatisfaction among the lower classes in these six states. This prediction, however, did not materialize, mainly because of the formation of the current class relations. 
The current nature of the working class in these states appears to be much more complicated than what the classical framework of analysis allows for. In all GCC countries, a relatively high percentage of the population consists of foreign working class who do not have any political voices whatsoever. These foreign workers often have no stable living condition, social security or economic perspective. As a consequence the neoliberal labor politics that has been adopted by GCC states had led to the emergence of transnational labor class. In fact, the emergence of a transnational labor class could assist GCC- based capitalist class to defuse the pressure they might receive from local laborers. This would insulate the state against domestic pressure that could redirect the economic structure towards national objectives rather than those of the TNPs.

At the same time, in none of these countries has the Huntingtonian prediction of the middle class as the engine of socioeconomic change been realized. Indeed, a general analysis of the middle class is rarely an accurate way to identify the characteristics of society or to predict its behavior. For instance, in terms of literacy, which is a major consideration for analyzing the middle class, there are many factors that can contextualize the process of education. These factors impact the resulting middle class and the direction and strength of the "political will" they would wield to bring about democratic changes. The difficulty with general middle-class analyses arises, in part, from the lack of accurate measurement indicia. For instance, it is unclear what level of schooling and college education in the GCC would be sufficient to create a viable push for democratic processes. On the other hand, in these countries it appears that the middle classes, by and large, believe that their economic well-being depends upon the ruling class. The GCC middle classes rely heavily on the rent channels that are provided and sustained by the royal families to 
maintain the status quo. This structure has been put in place over the past several decades. As a result, a high percentage of indigenous people in the GCC are "increasingly being distanced from the forces of production and thus sidelined into becoming a rentier class dependent on government subsidies, rather than a distinct proletariat or middle class" (Davidson, 2013, P. 6). This phenomenon, of course, has been contextualized within a global context in which the "TNS seeks to create and maintain the pre-conditions for the valorization and accumulation of capital in the global economy, which is not simply the sum of national economies and national class structures and requires a centralized authority to represent the whole of competing capitals, the major combinations of which are no longer "national" capitals" (Robinson, 2001, P. 167).

The renting channels that are controlled by the GCC transnational elites could bring about a new class formation through a series of what I call "semi-redistribution policies." I use the term "semi-redistribution" because of the very fact that such policies have not decreased the gap among social classes in any notable way. As result, we may refer to the GCC states as transnational rentier states. This term refers to the political context in which these states have been transnationalized. The term also indicates the fact that, due to the rentier nature of the states, societies are prone to be subjugated to the decisions of the elites, including those decisions aimed at further transnationalization in this structure.

\section{GCC Transnational Space}

In the following sections I explain the "GCC transnational space" that has been promoted by the GCC-based transnational elites and the TCC. To do so, it is necessary to understand the major components of this transnational space. The first is the GCC 
Sovereign Wealth Funds (SWFs) that are significant financial institutions (reliable sources for TNPs) controlled by royal families. The second institution is GCC educational system that is heavily influenced by capitalist principles. The third major component is the GCC labor market.

\section{Sovereign Wealth Funds}

The first significant institutions are Sovereign Wealth Funds (SWFs). According to the International Working Group (IWG) of Sovereign Wealth Funds, SWFs can be defined as "special-purpose investment funds or arrangements that are owned by the general government. Created by the general government for macro-economic purposes, SWFs hold, manage, or administer assets to achieve financial objectives, and they employ a set of investment strategies that include investing in foreign financial assets" (Sultan and et al., 2012, P. 49).

The GCC-based SWFs is arguably a clear manifestation of the "super national economic and political institutions that begin to acquire the characteristics of a transnational state" (Robinson, 2001, P. 533). In the GCC the empirical evidence indicates that the conventional way of understanding SWFs may be misleading. Foremost, the process of decision making in the GCC through SWFs transactions is, by and large, limited to the royal families. On the other hand, the stated purpose of SWFs is to improve national economies by preventing the Dutch Disease or by preserving the benefits of natural resources for the future generations (e.g. through the use of the proceeds from those resources in improving the economic infrastructures of the country). In the GCC, however, it is not clear how much of these funds are invested in infrastructural development. This uncertainty arises in part from the fact that "they publish no accounts, 
provide inconsistent aggregate asset figures to the media, and say nothing about their investment strategies." Moreover, these funds made a "very public contribution to propping up ailing U.S. banks during the acute phase of the 2008 global financial crisis" (Schwartz, 2012, P. 519). Meanwhile, the Persian Gulf Arab states' SWFs are controlled by individual actors rather than public entities. As a result of this model of management, these funds appear to have become an important sources of capital for personal investments. Table 4 provides some basic information on significant SWFs in the GCC region. It shows the enormous financial capacity of the GCC-based SWFs.

\begin{tabular}{|c|c|c|c|c|}
\hline Country & Sovereign Fund Name & $\begin{array}{c}\text { Assets as of } \\
2012 \text { (in Billion \$) }\end{array}$ & Inception & Origin \\
\hline $\begin{array}{l}\text { UAE- Abu } \\
\text { Dhabi }\end{array}$ & $\begin{array}{c}\text { Abu Dhabi Investment } \\
\text { Authority }\end{array}$ & 627 & 1976 & Oil \\
\hline $\begin{array}{l}\text { Saudi } \\
\text { Arabia }\end{array}$ & SAMA Foreign Holdings & 532.8 & $\mathrm{n} / \mathrm{a}$ & Oil \\
\hline Kuwait & $\begin{array}{c}\text { Kuwait Investment } \\
\text { Authority }\end{array}$ & 296 & 1953 & Oil \\
\hline Qatar & Qatar Investment Authority & 100 & 2005 & Oil \\
\hline $\begin{array}{l}\text { UAE- } \\
\text { Dubai }\end{array}$ & $\begin{array}{c}\text { Investment Corporation of } \\
\text { Dubai }\end{array}$ & 70 & 2006 & Oil \\
\hline $\begin{array}{l}\text { UAE-Abu } \\
\text { Dhabi }\end{array}$ & $\begin{array}{l}\text { International Petroleum } \\
\text { Investment Company }\end{array}$ & 58 & 1984 & Oil \\
\hline $\begin{array}{l}\text { UAE-Abu } \\
\text { Dhabi }\end{array}$ & $\begin{array}{l}\text { Mubadala Development } \\
\text { Company }\end{array}$ & 48.2 & 2002 & Oil \\
\hline Bahrain & Mumtalakat Holdings & 9.1 & 2006 & $\begin{array}{c}\text { Non- } \\
\text { commodity }\end{array}$ \\
\hline Oman & State General Reserve Fund & 8.2 & 1980 & Oil \& Gas \\
\hline
\end{tabular}

Table 4: The GCC Sovereign Wealth Funds (SWFs)

Source: SWF Asset Allocation Report 2012, Conducted by Sovereign Wealth Fund Institute, Inc. 
GCC-based SWFs are playing a crucial role in transnationalization of capital and (re)consolidation of the GCC transnational elites' power in TCC. For instance, in his book, New Post-Oil Arab Gulf, Sultan claims:

"KIA [Kuwait Investment Authority], which was established in 1953, is well known on the international scene for its 7.1 percent stake in Daimler Chrysler dating back to 1969 and its 3.3 percent share in British Petroleum (BP). More recently, KIA made headlines by becoming the largest investor in the Industrial and Commercial Bank of China (\$720 million) in 2006, followed by a combined \$5 billion investment in Citigroup and Merrill Lynch in late 2007/early 2008, among other investments.” (Sultan, 2012, P. 55)

Interestingly, the mainstream centers of the transnational capitalist class have applauded the GCC states' economic policies. According to an article produced in 1997 by the Middle Eastern Department of the IMF, "The GCC countries have already completed most of the crucial stages of liberalization and financial reform." This liberalization was succeeded by the creation of many SWFs in the GCC that play an important role in returning petrodollars into the global financial market and by reinvesting it in mostly Western countries. At the same time, these funds have appeared as a reliable source of capital for many GCC-based financial sectors that play a decisive role in financing the private sector of global economy by injecting large sums of cash into the system, mainly during the periods of financial crisis, such as the one in 2008. Furthermore, the position of the GCC elites in the TCC has been strengthened by the segmentation of production according to neoliberalism. The GCC elites play a significant role in the global economy of oil and the financial transactions of petrodollars. 


\section{GCC Segmented Education System}

The second important institution is Education. The education system is not only important as an institution itself. It also provides a good case to study that manifests the class relations in a transnationally oriented structure of GCC. On the one hand, many of the GCC elites are educated in top ranking private schools and colleges in the West. This is not surprising, as the TCC members have "similar life styles," including the "pattern of higher education" (Sklair, 2000). On the other hand, the GCC states embarked on ambitious educational programs that resulted in the establishment of many Western-style schools and universities in the GCC.

It has been argued that "the more well-to-do a nation, the greater the chances that it will sustain democracy" (Lipset, 1959, P. 75). In other words, many scholars of political change believe that democracy and economic development have a positive correlations with each other. They maintain that an economic development that increases levels of industrialization, higher education, and urbanization can help create the degree of national stability necessary for a democratic system to emerge and survive. However, despite this mainstream theory of democratization, in the GCC states solid economic development, rapid urbanization and the dramatic rise in the number of educational institutions have produced the exact opposite result: democracy is largely absent within these nations, and the authoritarian regimes enjoy a high degree of stability.

The GCC education systems that were originally designed by the TCC play a significant role in the survival of repressive state apparatuses in the GCC countries. Arguably, one of the most significant aspects of the relationship between the GCC elites and TCC is the educational ties between the two, which has led to further cohesion between 
them. The educational ties link the GCC elite firmly to the "social clubs" embedded within the TCC, while, at the same time, they use rents earned from their privileged status to either pay off, repress, or ideologically incorporate the majority of their populations.

The importance of the non-organic educational system in this region cannot be overstated. The non-organic educational system ties the GCC elites to particular educational opportunities that are distinct and apart from their societies. This artificially imposed educational system has been embedded and become more and more sophisticated in the past few decades. To provide insight into the educational background of the GCC transnational elites, and how that background is irrelevant to the history and culture of this region, Table 5 provides some information about a number of most influential economic and political figures.

In terms of the domestic educational system, there are currently many Westernstyle schools in these countries. These schools have emerged in parallel with the immigration of many Western nationals to the GCC for high-paying job opportunities. There are quite a number of formal and informal affiliations between Western educational intuitions and the GCC educational institutions. A main motivation for these formal and informal affiliations appears to have been economic advantage to the Western institutions. Table 6 lists some of the Western or Western-style educational institutions in the one of the most globalized cities in the GCC, namely Dubai. 


\begin{tabular}{|c|c|c|c|c|c|c|}
\hline NAME & TITLE & ORIGIN & \begin{tabular}{|l|} 
COMPAN \\
Y
\end{tabular} & \begin{tabular}{|l|} 
INDUSTR \\
Y
\end{tabular} & Education & Other Occup ations \\
\hline $\begin{array}{l}\text { Sheikh Tamim bin Hamad bin } \\
\text { Khalifa A1 Thani }\end{array}$ & $\begin{array}{l}\text { Emir of the State of } \\
\text { Qatar }\end{array}$ & Qatar & & & $\begin{array}{l}\text { Sherborne School, Harrow School, Royal } \\
\text { Military Academy Sandhurst (RMAS) }\end{array}$ & \\
\hline $\begin{array}{l}\text { Abdullah bin Nasser bin Khalifa } \\
\text { Al Thani }\end{array}$ & Prime Minister of Qatar & & & & Durham Military College & \\
\hline \begin{tabular}{|l|} 
Qaboos bin Said A1 Said \\
\end{tabular} & Sultan of Oman & & & & Royal Military Academy Sandhurstqab & \\
\hline $\begin{array}{l}\text { Hamad bin Isa bin Salman Al } \\
\text { Khalifa }\end{array}$ & King of Bahrain & & & & Leys public school in Cambridge & \\
\hline $\begin{array}{l}\text { Mohammed bin Rashid Al } \\
\text { Maktoum }\end{array}$ & $\begin{array}{l}\text { Prime Minister and Vice } \\
\text { President of Dubai }\end{array}$ & & & & $\begin{array}{l}\text { Bell Educational Trust's English L anguage } \\
\text { School }\end{array}$ & \\
\hline $\begin{array}{l}\text { Prince Alwaleed Bin Talal Bin } \\
\text { Abdulaziz Alsaud }\end{array}$ & Chairman & KSA & $\begin{array}{l}\text { Kingdom } \\
\text { Hol ding }\end{array}$ & Finance & Menlo College, Syracuse University & $\begin{array}{l}\text { "Citigroup's largest } \\
\text { individual shareholder" }\end{array}$ \\
\hline $\begin{array}{l}\text { Sheikh Ahmed Bin Saeed Al } \\
\text { Maktoum }\end{array}$ & Chairman & UAE & $\left|\begin{array}{l}\text { Emirates/E } \\
\text { mirates } \\
\text { NBD }\end{array}\right|$ & Transport & University of Denver & $\begin{array}{l}\text { "chairman of Dubai's } \\
\text { biggest bank, Emirates } \\
\text { NBD, and of Dubai } \\
\text { World, the conglomerate } \\
\text { that includes the world's } \\
\text { third-biggest ports } \\
\text { company, DP World". }\end{array}$ \\
\hline Khalid Al Falih & CEO and president & KSA & ARAMCO & In dustry & Texas A\&M University & $\begin{array}{l}\text { "Member of American } \\
\text { Society of Mechanical } \\
\text { Engineers (ASME), the } \\
\text { International } \\
\text { Association for Energy } \\
\text { Economics (IAEE) and } \\
\text { Oxford Energy Policy } \\
\text { Club" }\end{array}$ \\
\hline Ali Bin Ibrahim Al Naimi & $\begin{array}{l}\text { Minister of Petroleum } \\
\text { and Mineral Resources }\end{array}$ & KSA & & Energy & $\begin{array}{l}\text { American University of Beirut, Lehigh } \\
\text { University, Stanford University }\end{array}$ & $\begin{array}{l}\text { Important role in oil } \\
\text { supply decissions }\end{array}$ \\
\hline Mohammed Al Mady & CEO & KSA & SABIC & In dustry & $\begin{array}{l}\text { University of Colorado Boulder, The } \\
\text { University of Wyoming, Honary Fellow of th } \\
\text { L ondon Business School }\end{array}$ & $\begin{array}{l}\text { "member of the U.S.- } \\
\text { Saudi Business Council; } \\
\text { the Economic Off set } \\
\text { Committee; and the } \\
\text { International Business } \\
\text { Council of the World } \\
\text { Economic Forum. Mr. } \\
\text { Al-Mady is a fellow of } \\
\text { the London Business } \\
\text { School". }\end{array}$ \\
\hline Mohamed Ali Alabbar & Chairman and CEO & UAE & Emaar & Real Estate & Seattle University & $\begin{array}{l}\text { "World Economic } \\
\text { Foroum (many times } \\
\text { represted UAE)." }\end{array}$ \\
\hline Ahmad Al Sayed & $\begin{array}{l}\text { Managing director and } \\
\text { CEO }\end{array}$ & Qatar & $\begin{array}{l}\text { Qatar } \\
\text { Holding }\end{array}$ & Finance & University of Boston, New York University & $\begin{array}{l}\text { "Harrods, London Stock } \\
\text { Exchange, Porsche and } \\
\text { Hochstein are a few of } \\
\text { the emblematic } \\
\text { companies that come to } \\
\text { mind under his } \\
\text { stewardship". }\end{array}$ \\
\hline Dr Fahad Al Mubarak & Governor & KSA & SAMA & Finance & University of Houston & $\begin{array}{l}\text { "was previously } \\
\text { chairman and managing } \\
\text { director of Morgan } \\
\text { Stanely Saudi Arabia" }\end{array}$ \\
\hline Mohamed Bin Issa Al Jaber & Chairman \& CEO & KSA & \begin{tabular}{|l|} 
MBI \\
Internation \\
al
\end{tabular} & Real Estate & $\begin{array}{l}\text { Honorary Doctor of Science degree from } \\
\text { University of Westminster and City } \\
\text { University }\end{array}$ & $\begin{array}{l}\text { "is founder, Chairman } \\
\text { and CEO of MBI Group, } \\
\text { an international } \\
\text { conglomerate which } \\
\text { spans Europe and the } \\
\text { Middle East. The Group } \\
\text { is a worldwide } \\
\text { investment in stitution } \\
\text { operating in the } \\
\text { hospitality, real estate, } \\
\text { fin ance, oil and gas and } \\
\text { food industries." }\end{array}$ \\
\hline
\end{tabular}

Table 5: The Educational Background of Major Economic and Political Figures in the $\mathrm{GCC}^{1}$

${ }^{1}$ See the expanded version of Table 5 in appendix 
Source: Business Press and Personal Websites

\begin{tabular}{|l|l|l|l|}
\hline \multicolumn{1}{|c|}{ School Name } & \multicolumn{1}{|c|}{ Level } & \multicolumn{1}{|c|}{ Curriculum } & \multicolumn{1}{|c|}{ Qualifications } \\
\hline American International School Dubai & K-12 & $\begin{array}{l}\text { Arabic, } \\
\text { Canadian, US }\end{array}$ & $\begin{array}{l}\text { MOE UAE, US HS } \\
\text { Diploma }\end{array}$ \\
\hline American School of Dubai & K-12 & US & AP, HS diploma \\
\hline British National Curriculum School & K-12 & UK & \\
\hline Cambridge High School Dubai & K-12 & Arabic, UK & A-level, IGCSE \\
\hline Cambridge International School Al Quoz & K-12 & UK & \\
\hline Cambridge International School Dubai & K-12 & UK & A-level, IGCSE \\
\hline Cambridge International School Dubailand & K-12 & UK & \\
\hline Cambridge International School Jumeirah Village & K-12 & UK & \\
\hline Collegiate American School & primary & US & $\begin{array}{l}\text { Common Core } \\
\text { Standards }\end{array}$ \\
\hline Community West First School Dubai & primary & UK & NC, FS1-Y2 \\
\hline Deans International School & K-12 & US & AP, SAT \\
\hline Deira International School & K-12 & UK & IB, IGCSE \\
\hline Deira Private School & primary & UK & NC \\
\hline Kings College Dubai & K-12 & UK & NC GCSE, A-Level \\
\hline Kings School Al Barsha & K-12 & UK & \\
\hline Kings School Dubai & primary & UK & NC FS KS1 KS2 \\
\hline Kings School Nad Al Sheba & K-12 & UK & EYFS, NC \\
\hline Latifa School for Girls & K-12 & UAE, UK & AS, A-level, GCSE \\
\hline Lycee Francais International Dubai & primary & French & \\
\hline Lycee Francais International Georges Pompidou & secondary & French & \\
\hline Lycee Francais International Meydan & primary & $\begin{array}{l}\text { Arabic, English, } \\
\text { French }\end{array}$ & IB \\
\hline Lycee Georges Pompidou Ecole primaire Dubai & primary & French & \\
\hline Lycee Libanais Francophone Prive & K-12 & French & \\
\hline Millfield School Dubai & & UK & \\
\hline
\end{tabular}

Table 6: Dubai Schools with Western Curricula ${ }^{2}$ Source: DubaiFAQs guide to Dubai

This phenomenon is not at all limited to Dubai. The spread of non-local educational systems in the region is yet another manifestation of the peculiar nature of the state in these six countries. Not only have the GCC elite, by and large, received their education from institutions that are geared towards the needs and interests of TCC, but the local population also receives a type of education that endorses, and even glorifies, the educational

\footnotetext{
${ }^{2}$ See the expanded version of Table 6 in appendix
} 
background of the ruling elite. It is difficult, therefore, for a graduate of these domestic western-style institutions to question the credibility of ruling elites who are graduates of Harvard, MIT or the London School of Economics.

The rise of foreign educational systems in the region coincided with the shift towards transnationally oriented economic institutions. The only part of the educational system that remains locally-oriented is the formal and informal religious education that the GCC transnational class uses to try to gain legitimacy for their rule. The growing chasm between these two styles of education has had serious consequences in various areas, especially the violent extremism in the region - a subject which is beyond the topic of this dissertation. It is sufficient to say that the "mainstream" educational institutions in today's GCC states rely on a class-based paradigm of development instead of serving as a sustainable and organic infrastructure for growth and production of knowledge within the GCC societies. At the same time, the impact of Western-style educational institutions on the societies remains limited. While in certain aspects, such as praise for Western technology, these educational systems have been quite successful, in other respects the GCC societies remain quite traditional. This creates yet another point of contrast and potential friction with most of the ruling elite, who are often immersed in Western ethos.

This kind of educational system is primarily geared towards enabling and protecting the interests of TCC members. As a result, it is not surprising that in many GCC countries what we may call an institutional dual-personality exists. On the one hand, a highly modernized and impressively globalized economic system is easily recognizable in these countries. On the other hand, a deeply traditional socio-political culture that philosophically rejects many of the tenants of modernism continues to thrive beneath 
modern skyscrapers. The tension between traditional and modern perspectives is arguably no greater anywhere than in the Muslim world. As Barry Rubin observes, “... no area in the world resists - at least explicitly - globalization to an extent equaling that of the Islamic Middle East" (Rubin, 2003, Yale Global Online). Not only globalization but also the socalled Westernization and modernization have been the target of serious criticism by many traditional voices in the Muslim world. At the same time, some of the most advanced institutions of the modern global economy have taken deep roots in this region's economies and politics, to the extent that one may argue this institutional dual- personality is the essence of GCC polities. In such a system, the most the educational systems have been able to do is facilitate upward mobility towards getting closer to the privileged TCC members (or what we may call "politics of contiguity" to the sources of power and wealth) rather than causing any major structural change in the socio-political status of these states and societies.

In fact, the GCC's educational systems are by design at the service of the transnational space rather than local economies. Indeed, such educational systems could significantly raise the level of literacy within the GCC societies. Yet, this is the type of literacy that is not likely conducive to any democratic change; and that is why general middle-class analyses and assessment of the so-called "democratic indicia," such as literacy, do not mean much when it comes to these peculiar state-societies. (I avoid the term nation-state for two reasons: first, the notion of nation in the context of this region is quite problematic, and it remains doubtful whether nations in the Western sense of the term exists there; second, in the GCC region states are by far the dominant force compared 
to the societies. Therefore, I will use the term state-society instead of nation-state to refer to these polities).

One indication of the inefficiency of the existing educational systems in bringing about organic and viable changes is the fact that an increasing number of graduates from these educational systems ultimately migrate and seek jobs in W estern countries or in other capitalist economies. This phenomenon occurs precisely because these graduates are first and foremost "global citizens" in the sense promoted by the mainstream globalization paradigm. They feel much more at home in London and New York than they might in their own societies. On the other hand, there are significant numbers of foreigners who are now enrolling in the GCC schools, both private and public. For instance, "only $15 \%$ of the 374 graduates that enrolled at King Abdullah University of Science \& Technology [a university with one of the largest endowments in the world] were Saudi nationals. Similarly, in academic year 2007-08, only 51\% of Qatar Education City's student population comprised Qatari nationals as opposed to the $70-75 \%$ target of the Qatari Foundation" (GCC Education Industry, 2010, P. 23). This high percentage of foreign enrollment in the educational institutions of the region also attests to the fact that these institutions are responsive to the educational needs of a "global" - i.e. TCC or TCC aspirant - audience, and not the needs of the indigenous populations.

It is significant that in the same country where the King Abdullah University of Science \& Technology, one of the world's most technologically advanced universities, has been established, the anti-West voices are arguably the most vocal. In 2012, the Grand Mufti of Saudi Arabia declared, "It is necessary to destroy all the churches of the region" (Broomhall, 2012, Arabian Business). His declaration may not have much significant 
impact in practice, especially in a country where there is not much freedom of religion to begin with. However, the declaration indicates the religious leader's extreme opposition to the mentality of those Saudi elites who are advocating one of the largest transfers of technology in human history from the West to Saudi Arabia.

The traditional societies of these states are not comfortable at all with modernization and Westernization. The history case of Iran illustrates another powerful example of this rejection of modernization by traditional religious powers. During the reign of the Shah, where fast Westernization and transfer of technology spawned within deeply traditional forces an uncontrollable resentment towards the system, which led to the Islamic Revolution of 1979. There is a certain level of truth in Rubin's observation that "the two factors that supposedly make globalization attractive are those of benefits and cultural synthesis" (Rubin, 2003, Yale Global Online). However, the current pattern of globalization, at least in the GCC region, revolves around the benefits to the TCC rather than broader societal benefit, and it does not lead to cultural synthesis. The absence of broader societal benefits can be found in some statistics reported in an EY study:

Only $29 \%$ of employers feel that education prepares students with necessary technical skills and only $19 \%$ agree that it prepares young people with the right attitude for work... $72 \%$ of young people stated that parents and family are the primary source of information about jobs." (Perspectives on GCC Youth Employment, 2014, P. 5)

The GCC countries offer generous social welfare systems in which education is free, and many other social security benefits are offered. At the same time, these social welfare systems are important means for (re)consolidation of the power of the ruling 
families and for the stability of the GCC transnational rentier states. For instance, the accesses to the benefits are not equally provided to all. Instead, different citizens, based on their family backgrounds and religions, have different levels of access to the government-distributed benefits. This allows the state to channel its financial support towards parts of the society that support the royal rule. It is not surprising that the welfare systems in these countries are almost completely controlled by the ruling families rather than an independent bureaucracy such as the de-centralized welfare structure of resource wealth distribution (i.e. the Nordic model). In other words, resources are in the hands of the royal families who decide who should have access to it and how much access they should have. Within the domestic economy that emerges around these transnational rentier states and their welfare systems, therefore, it is not surprising that, for young people, connections are more important than educational background in finding jobs.

Thus, the other aspect of the GCC's governmental design of the educational system is the peculiar nature and objectives of the GCC welfare systems. Similar to the educational systems, the welfare systems have not been designed in such a manner that they would reduce the gaps among different social classes. At the same time, the life-style of the ruling elites and the wealthy exacerbate the sense of social injustice among lower classes. Thus, the concept of poverty becomes a relational concept rather than a certain economic index that can be measured based on fixed mainstream parameters, such as income or access to food and other life necessities. Accordingly, despite the unprecedented economic growth and despite the relatively positive economic indexes, the highly uneven economic statuses of different groups of citizens have created a cause for resentment. This 
resentment among the lower classes, in turn, has fueled various destructive forces ranging from socioeconomic corruption to radicalism. In particular, corruption has been a natural response to domestic economic systems where some are included in while others excluded from having access to the proceeds from shared natural resources.

\section{Labor Market}

It is important to note again, that the arrangements of social classes in the GCC countries are complicated. The arrangements become somewhat clearer when viewed as a transnationally- oriented structure rather than the traditional nationally-oriented framework. The following chart produced by journalist Ahmed Al Omran indicates that unusually high percentages of the population in the GCC countries consist of foreign workers.

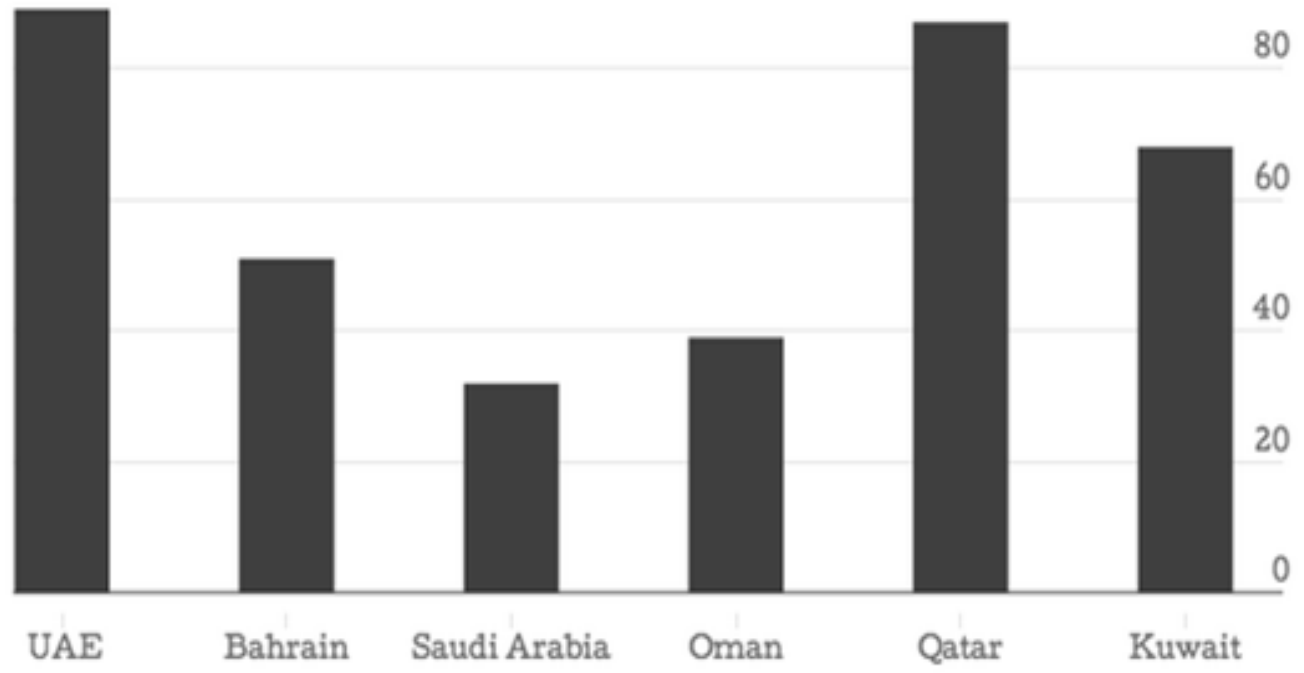

Chart 1: Percentage of Foreign Workers of Total Population in GCC in 2011 Source: Borrowed from : http://www.timeskuwait.com/Times_Kuwait-3rd-highest-inexpats-numbers-in-GCC 
The dependency of the private sector in most of the GCC countries on foreign workers has been dramatically increasing in the past few decades. Table 7 below provides the "net migration"3 to the GCC countries from 1980 to 2013.

\begin{tabular}{|l|r|l|r|l|l|l|l|}
\hline & $\begin{array}{l}\text { 1980- } \\
\mathbf{1 9 8 3}\end{array}$ & $\begin{array}{l}\text { 1984- } \\
\mathbf{1 9 8 8}\end{array}$ & $\begin{array}{l}\text { 1989- } \\
\mathbf{1 9 9 3}\end{array}$ & $\begin{array}{l}\mathbf{1 9 9 4 -} \\
\mathbf{1 9 9 8}\end{array}$ & $\begin{array}{l}\text { 1999- } \\
\mathbf{2 0 0 3}\end{array}$ & $\begin{array}{l}\text { 2004- } \\
\mathbf{2 0 0 8}\end{array}$ & $\begin{array}{l}\text { 2009- } \\
\mathbf{2 0 1 3}\end{array}$ \\
\hline Bahrain & 3195 & 12899 & 5480 & 44472 & 143336 & 293196 & 22081 \\
\hline Kuwait & 102745 & 118980 & 601874 & 125523 & 200174 & 448950 & 299999 \\
\hline Oman & 81500 & 9000 & 65500 & 209243 & 106793 & 32567 & 1029938 \\
\hline Qatar & 101975 & 57517 & -22453 & 42840 & 170402 & 857088 & 499998 \\
\hline Saudi Arabia & 1391626 & 538413 & 121511 & 876891 & 2197524 & 157126 & 300000 \\
\hline $\begin{array}{l}\text { United Arab } \\
\text { Emirates }\end{array}$ & 174444 & 259505 & 327575 & 464455 & 863784 & 3812193 & 514042 \\
\hline GCC & 1855485 & 996314 & 347283 & 408844 & 3682013 & 5601120 & 2666058 \\
\hline
\end{tabular}

Table 7: Net Migration to the GCC Countries

Source: World Bank (http://data.worldbank.org/indicator)

\footnotetext{
${ }^{3}$ According to the World Bank: "Net migration is the net total of migrants during the period, that is, the total number of immigrants less the annual number of emigrants, including both citizens and noncitizens. Data are five-years estimates". (http://data.worldbank.org/indicator/SM.POP.NETM?page=6)
} 


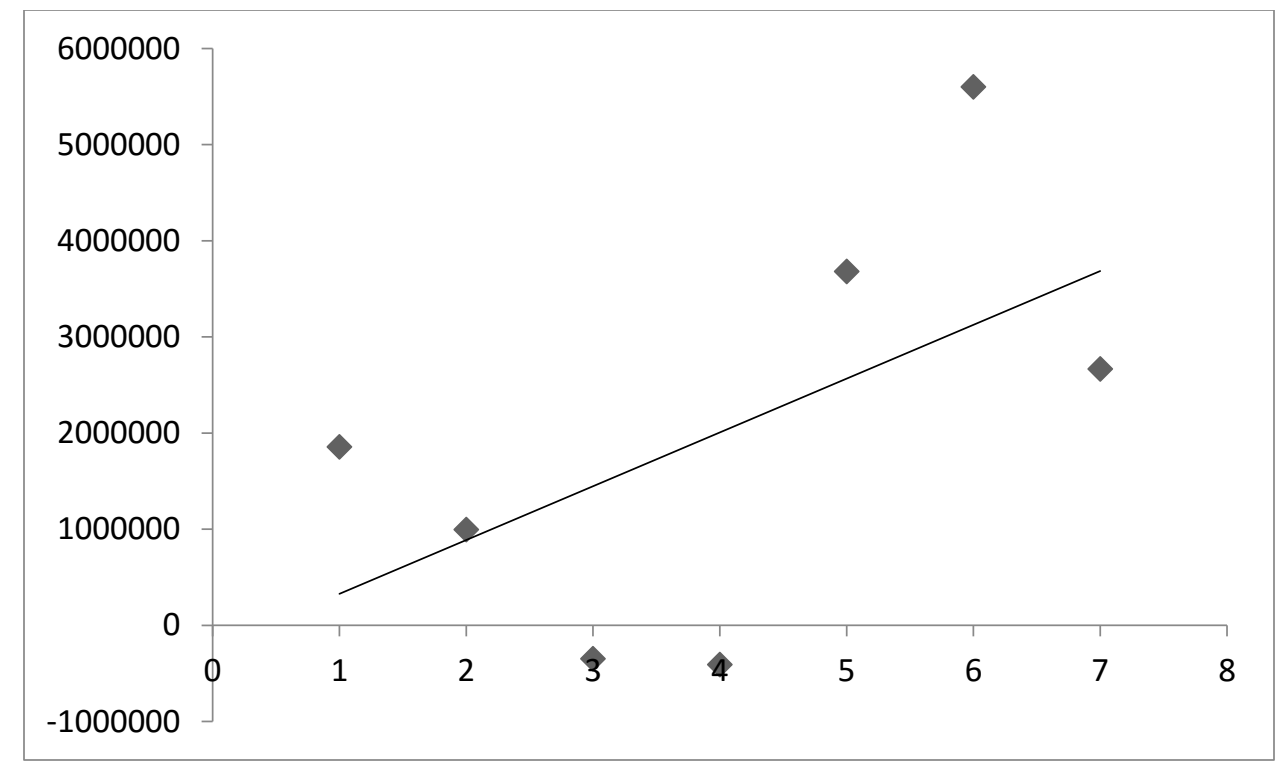

Figure 2: Trend Line of Net Migration in the GCC Countries Source: World Bank (http://data.worldbank.org/indicator)

Figure 2 shows the trend line of net migration. Despite the increasing migration of foreign laborers to the GCC countries, which has propelled the extraordinary economic development in the region, the living conditions of these labor forces have not improved. The World Report 2014 by the Human Rights Watch cites many unacceptable living conditions that foreign labors have to endure in these countries, ranging from "unpaid wages," "physical abuse," "passport confiscation," and "unsafe housing" to "exploitation" and "servitude" (World Report, 2014). Obviously, the extent of these problems differs from one country to another. However, the economic structures of all GCC countries depend on cheap labor: "[f]or transnational capital, working class immiseration is just another way to reduce cost margins as firms expand their cross-border investment" (Cox, 2012, P. 15). 
Finally, population growth remains an important challenge for these countries - a challenge that can exacerbate the level of inequality in the future. In a project conducted by The Economist in 2010, it was estimated that the GCC countries will face $30 \%$ population growth until 2020 (The GCC in 2020, 2010, P.1). Such a rapid growth requires states to produce many more new jobs. As mentioned before, currently, considerable percentages of the GCC working class are immigrants. (See Figure 3 below.)

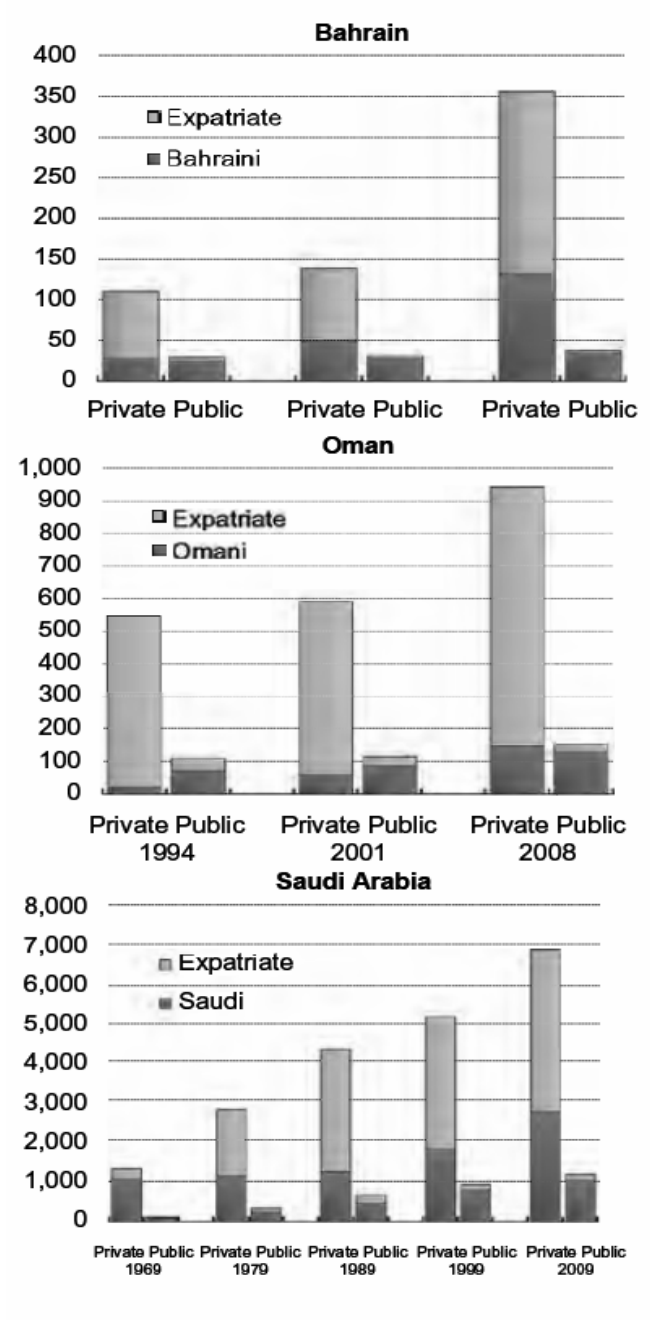

Sources: Country authorities.

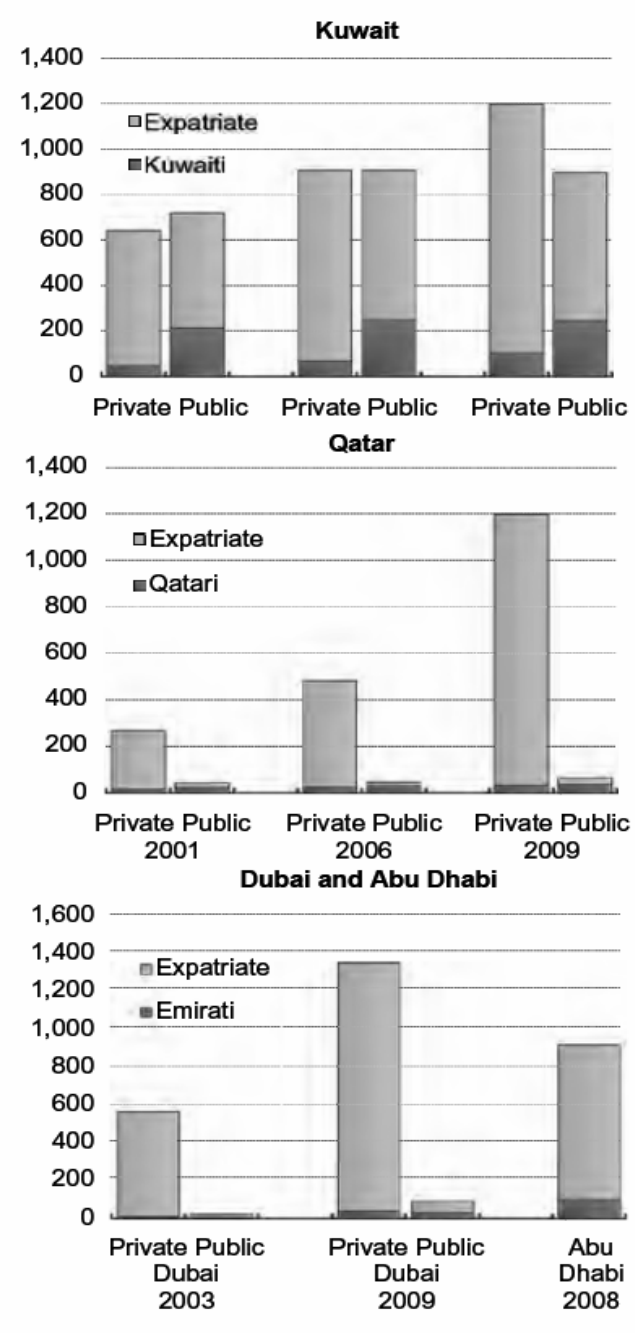

Tjshome.com/i

Figure 3: Labor Force by Sector and Origin, 1969-2009

Source: Borrowed from https://www.imf.org/external/pubs/ft/dp/2011/1101mcd.pdf, P.5 
Even if the GCC states prove successful in the extremely difficult task of creating so many new jobs, it is doubtful that these jobs will benefit the indigenous populations or whether these populations would agree to fill these job positions. This is because the current labor politics in the GCC region favors transnational labor class - who are poorly paid and need not be protected by national regulations and policies. Moreover, the GCC societies have benefited to various degrees from social welfare systems and from low-skill foreign workers for so long that it is quite unlikely that the indigenous populations will compete with foreign workers for low-paying, low-skill job openings. Therefore, the transnational structure of capital accumulation that is the essence of the GCC political economies does not provide for the local population. Consequently, the job market cannot absorb the future population growth in a way in which locals would have a standard level of living as good as their ancestors have had.

\section{Conclusion}

"My Grandfather rode a camel, my father rode a camel, I drive a Mercedes, my son drives a Land Rover, his son will drive a Land Rover, but his son will ride a camel" (The National UAE, 2010). This observation by Sheikh Rashid bin Saeed Al Maktoum, the former vice president of UAE, illustrates how the ascendance of transnational activities have derailed any organic political and socioeconomic structure within the Gulf States. In other words, the modern political economy of the GCC is dominated by transnational actors whose business activities are more compatible with the global structure of transnational capital accumulation rather than advancing any national (or regional) economic interests.

This chapter has attempted to shed light on several aspects of the political economy of the transnational elite in the GCC states. It is the promise of globalization that economic 
integration as well as cultural interactions can provide a ground for sustainable economic development. At the same time, many studies of democratization tell us that enhancement of learning and education within societies is an important stepping stone towards democratic change. However, where the middle class and the working class are essentially excluded from the process of decision making and the economic interactions are micromanaged by the ruling elites, both of the above propositions are dubious.

In the GCC region, these elites are well-educated and successful in their transnational business activities. They speak the "language of the world" (i.e. West), and they share the "globalized (i.e. capitalist) mentality." But when it comes to the national and local levels of analysis, these elites, as loyal custodians of the interests of the TCC, must play the role of controllers and shock-absorbers in their societies, insulating the TCC from local unrest. This, in effect, has created a "race to the bottom" for further transnationalization of local economies combined with suppressive politics. What is missing, in the words of Robert Wade, is a "strategic management of [international] trade, so as to curb the race-to-the-bottom effects of export-led growth, and foster domestic industry and services that would provide better livelihood and incomes for the middle and working classes" (Wade, 2008, P.20). On the other hand, the image of transnational globalization in the region cannot be completely understood without examining the crucial role of the GCC-based transnational elites. This chapter provides insight into the unusual combination in the GCC countries of the low level of development in the infrastructure of the local economies, on the one hand, and the high level of development in transnational economic activities. The next chapter will extend the scope of the argument advanced in this 
chapter by analyzing the transnational ties between GCC transnational structures and those of global transnational capital accumulation.

This chapter also considered the relationship between the amount of wealth in this region and the authoritarian nature of the ruling regimes. To understand this relationship, one should not focus only on domestic factors. The relationships between the GCC transnational elites and TCC have shaped the current domestic contexts for authoritarian regimes in important ways; and because the continuation of these regimes is in the interest of the transnational structure of capital accumulation, it is unlikely that any democratic change materializes in the foreseeable future. As the chapter explored, the GCC-based elites have been evolving from a national/international context to transnational context. Accordingly, any state-centric approach or state-society frameworks that are based upon the mainstream understanding of the notion of "state" cannot provide an accurate understanding of many fundamental processes in the GCC region.

It is important to note that one of the recurring geostrategic aspects of the Persian Gulf region has been the emergence of political vacuums during various historical periods. In the early modern history of the Persian Gulf, this vacuum was filled by the British Empire. After the British had to relinquish their power in the region in the 1950s, the United States filled the vacuum. In Persian Gulf in History, Gary Sick writes:

"Throughout, U.S. interests in the Persian Gulf region were simple and consistent, conceived from the start in global, strategic terms: first, to ensure access by the industrialized world to the vast oil resources of the region; and second, to prevent any hostile power from acquiring political or military control over those resources" (Potter, 2008, P. 295). 
In the context of this political vacuum the nature of the power that the GCC states have is unclear. Some scholars argue that energy resources available in the GCC region are the primary reason that the global economy should keep this region as stable as possible. On the other hand, the geostrategic location of the GCC region is a significant factor. While there are some truths in these assertions, the nature of state power in the GCC countries cannot be understood without contextualizing the GCC's transnational elites in the TCC. It can be argued that, with the dramatic increase in the power of the TCC in the GCC region over the past two decades it has been the transnational structure of capital accumulation that has filled the political vacuum in that region. Accordingly, one cannot analyze the GCC states without the significant role of its transnational elites, who have created in the course of many decades a number of transnational rentier states. These transnational rentier states have heavily influenced various aspects of the GCC countries' institutional settings including the economic, political, social, and educational institutions. 
Appendix I: Expanded Versions of Table 5 and Table 6 
Table5: The Educational Background of Major Economic and Political Figures in the GCC

\begin{tabular}{|c|c|c|c|c|c|c|}
\hline NAME & TITLE & ORIGN & COMPANY & INDUSTRY & Education & Other Occupations \\
\hline $\begin{array}{l}\text { Sheikh Tamim bin Hamad bin } \\
\text { Khalifa Al Thani }\end{array}$ & $\begin{array}{l}\text { Emir of the State of } \\
\text { Qatar }\end{array}$ & Qatar & & & $\begin{array}{l}\text { Sherborne School, Harrow School, Royal Military } \\
\text { Academy Sandhurst (RMAS) }\end{array}$ & \\
\hline $\begin{array}{l}\text { Abdullah bin Nasserbin } \\
\text { Khalifa Al Thani } \\
\end{array}$ & Pime Minister of Qatar & & & & Durham Military College & \\
\hline Qaboos bin Said Al Said & Sultan of Oman & & & & Royal Military Acadenry Sandhurstqab & \\
\hline $\begin{array}{l}\text { Hamad bin Isa bin Salman Al } \\
\text { Khalifa }\end{array}$ & King of Bahrain & & & & Leys public school in Cambridge & \\
\hline \begin{tabular}{|l|} 
Khalifa bin Zayed bin Sultan Al \\
Nahyan
\end{tabular} & President of the UAE & & & & Royal Military Academy Sandhurst & \\
\hline \begin{tabular}{|l|} 
Mohammed bin Rashid Al \\
Maktoum
\end{tabular} & $\begin{array}{l}\text { Prime Minister and Vice } \\
\text { President ofDubai }\end{array}$ & & & & Bell Educational Trust's English Language School & \\
\hline $\begin{array}{l}\text { Prince Alwaleed Bin Talal Bin } \\
\text { Abdulaziz Alsaud }\end{array}$ & Chaiman & KSA & $\begin{array}{l}\text { King dom } \\
\text { Holding } \\
\end{array}$ & Finance & Menb College, Syracuse University & $\begin{array}{l}\text { "Citig roup's larg est individual } \\
\text { shareholder" }\end{array}$ \\
\hline $\begin{array}{l}\text { Sheikh Ahmed Bin Saeed Al } \\
\text { Maktoum }\end{array}$ & Chaiman & UAE & $\begin{array}{l}\text { Emirates/Emirat } \\
\text { es NBD }\end{array}$ & Transport & University of Denver & $\begin{array}{l}\text { "chairman of Dubai's big gest bank, } \\
\text { Emirates NBD, and of Dubai World, } \\
\text { the cong lomerate that includes the } \\
\text { world's third-big gest ports company, } \\
\text { DP World". }\end{array}$ \\
\hline Khalid Al Falih & CEO and president & KSA & ARAMCO & Industry & Texas A\&MUniversity & $\begin{array}{l}\text { "Member of American Society of } \\
\text { Mechanical Eng ineers (ASME), the } \\
\text { International Association for Energy } \\
\text { Economics (IAEE) and Osford Energy } \\
\text { Policy Club" }\end{array}$ \\
\hline Ali Bin Jrahim AlNaimi & $\begin{array}{l}\text { Minister of Petroleum } \\
\text { and Mineral Resources }\end{array}$ & KSA & & Energy & $\begin{array}{l}\text { American University of Beirut, Lehigh University } \\
\text { Stanford University }\end{array}$ & $\begin{array}{l}\text { Important role in oil supply } \\
\text { decissions }\end{array}$ \\
\hline Mohammed AlMady & CEO & KSA & SABIC & Industry & $\begin{array}{l}\text { University of Colorado Boulder, The University of } \\
\text { Wyoming, Honary Fellow of th London Business } \\
\text { School }\end{array}$ & $\begin{array}{l}\text { "member of the US.SaudiBusiness } \\
\text { Council; the Economic Offset } \\
\text { Committee; and the International } \\
\text { Business Council of the World } \\
\text { Economic Forum. Mr. Al-Mady is a } \\
\text { fellow of the London Business } \\
\text { School". }\end{array}$ \\
\hline Mohamed Ali Alabbar & Chaiman and CEO & UAE & Emaar & Real Estate & Seattle Lniversity & $\begin{array}{l}\text { World Economic Foroum (many times } \\
\text { represted UAE). } \\
\text { (http://the financialdaily.com/articles/ } \\
\text { ViewArticleDetail.aspr?ArticleID=356 } \\
\text { 2) }\end{array}$ \\
\hline Ahmad Al Sayed & $\begin{array}{l}\text { Managing director and } \\
\text { CEO }\end{array}$ & Qatar & Qatar Holding & Finance & University of Boston, New York University & $\begin{array}{l}\text { "Harrods, London Stock Exchange, } \\
\text { Porsche and Hochstein are a few of } \\
\text { the emblematic companies that come } \\
\text { to mind under his stewardship". }\end{array}$ \\
\hline Dr Fahad Al Mubarak & Governor & KSA & SAMA & Finance & University of Houston & $\begin{array}{l}\text { "was previously chairman and } \\
\text { managing director of Morgan Stanely } \\
\text { Saudi Arabia" }\end{array}$ \\
\hline Mohamed Bin Issa Al Jaber & Chaiman \& CEO & KSA & $\begin{array}{l}\text { MBI } \\
\text { International }\end{array}$ & Real Estate & $\begin{array}{l}\text { Honorary Doctor of Science degree from University } \\
\text { of Westminster and City University }\end{array}$ & $\begin{array}{l}\text { "is founder, Chairman and CEO of } \\
\text { MBI Group, an international } \\
\text { cong lomerate which spans Europe } \\
\text { and the Middle East. The Group is a } \\
\text { worldwide investment institution } \\
\text { operating in the hospitality, real } \\
\text { estate, finance, oil and gas and food } \\
\text { industries." }\end{array}$ \\
\hline
\end{tabular}




\begin{tabular}{|c|c|c|c|c|c|c|}
\hline NAMIE & TIILL & ORIGN & COMPANY & INDUSTRY & Iducation & Other Occupations \\
\hline Baks bin Ladin & Chaiman & KSA & $\begin{array}{l}\text { BinLaden } \\
\text { Group }\end{array}$ & Real Estate & University of Miami & \\
\hline Lubna Olayan & CEO & KSA & $\begin{array}{l}\text { Olayan } \\
\text { Financing } \\
\text { Company }\end{array}$ & Finance & Comell University,Indiana University & $\begin{array}{l}\text { "A member of the Intemational } \\
\text { Business Council of the World } \\
\text { Economic Forum, she is also on the } \\
\text { Arab Business Council's executive } \\
\text { committee" }\end{array}$ \\
\hline Khaldoon Khalifa AlMubarak & $\begin{array}{l}\text { CEO and managing } \\
\text { director }\end{array}$ & UAE & Mubadala & Finance & Tufts University, Boston, Massachusetts & $\begin{array}{l}\text { "Member of Intemational Advisory } \\
\text { Board at Russian Direct Investment } \\
\text { Fund, He has been a Director of } \\
\text { Ferrari S.p.A, the Chairman of } \\
\text { Manchester City Football Club } \\
\text { Limited" }\end{array}$ \\
\hline SheilhaLubna Al Qasimi & $\begin{array}{l}\text { Minister of Foreign } \\
\text { Trade }\end{array}$ & UAE & & Govemment & Califormia State University & \\
\hline Abdul Azziz Al Ghurair & CEO & UAE & Mashreq & Finance & $\begin{array}{l}\text { Califormia Polytechnic State University (Honors } \\
\text { Degree) }\end{array}$ & \\
\hline Mohammed Alshaya & Chaiman & Kuwait & $\begin{array}{l}\text { MH Alshaya } \\
\text { Group }\end{array}$ & Retail & wharton school of business & \\
\hline $\begin{array}{l}\text { Sheilh Sulaiman bin Abdul- } \\
\text { Aziz Al-Rahi }\end{array}$ & Chaiman & KSA & Al-Rajhi Bank & Finance & & \\
\hline Akbar Al Baker & CEO & Qatar & Qatar Airways & Transport & & $\begin{array}{l}\text { "He has been a Non Executive } \\
\text { Director of Heathrow Airport } \\
\text { Holdings Ltd. since February } 2013 . \\
\text { He served as a Director of Cargolux } \\
\text { Airlines International SA since } \\
\text { September 8, 2011". }\end{array}$ \\
\hline Mansour Saleh Al-Maiman & Chaiman & KSA & $\begin{array}{l}\text { National } \\
\text { Commercial } \\
\text { Bank }\end{array}$ & Finance & University Of Dallas & \\
\hline Abdulla Nasser Al Suwridi & Director General & UAE & ADNOC & Energy & University of Wisconsin & \\
\hline $\begin{array}{l}\text { Sheilh Khalid Bin Khalifa Al } \\
\text { Thari }\end{array}$ & CEO & Qatar & Qatargas & Energy & Pacific Lutheran University & \\
\hline Thoraya Ahmed Obaid & Shura Council Member & KSA & & Govemment & Wayne State University & \\
\hline Ali Shareef AlEmadi & Group CEO & Qatar & $\begin{array}{l}\text { Qatar National } \\
\text { Bank } \\
\end{array}$ & Finance & University of Arizona & \\
\hline Sheith Saleh Kamel & Chaiman & Chaiman & Dallah Albaraka & Finance & University of Califorma & $\begin{array}{l}\text { "He serves as Chairman of Egyptian } \\
\text { Saudi Finance Bank, Egypt; Al Amin } \\
\text { Bank, Bahrain; Albaraka Bank } \\
\text { Lebanon; Arab Media Company, } \\
\text { Saudi Arabia and Arab Radio \& } \\
\text { Television, Cayman Islands". }\end{array}$ \\
\hline Hassan Abdullah Al Thawadi & Secretary General & Qatar & \begin{tabular}{|l} 
Qatar 2022 \\
Supreme \\
Committee \\
\end{tabular} & $\begin{array}{l}\text { Culture and } \\
\text { Society }\end{array}$ & The University of Sheffield & Director of Hassad Austrabia Pty Ltd. \\
\hline
\end{tabular}


Table 6: Dubai Schools with Western Curricula

\begin{tabular}{|c|c|c|c|c|}
\hline MAVE & IIILE & ORIGN CONPANY & NDLTTRY & Edelcation \\
\hline Mahmood Hashim Al Koohej & CEO & Bahrain Muntalakat & Finance & Stafforddhire University, Henley Business School \\
\hline Sheikh Ahmed bin Jassim Al Thani & DirectorCeneral & Oatar Allazeera & Media & Imperial Colleger Business School, Tepper School of Business \\
\hline Hayat Sindi & Medical researcher & KSA Diagnostics for All & Science & King's College London, University of Cambridge \\
\hline Omar K Alghanim & CEO & \begin{tabular}{|l|l} 
Kuwwatt & $\begin{array}{l}\text { Alghanim } \\
\text { Industries }\end{array}$ \\
\end{tabular} & Industity & New YorkChiviversity, Hararard Businesss School \\
\hline Abdullatif al-Othman & Covernor and Chaiman & KSA SAGIA & Finance & Massachusetts Institute of Technology \\
\hline $\begin{array}{l}\text { Sheikha Hanadi Bint Nasser Bin } \\
\text { Khalid Al Thani } \\
\end{array}$ & Businesswoman & Qatar & Finance & London Business School, University Of London, \\
\hline Mohammed Jameel & President & \begin{tabular}{|l|l} 
KSA & $\begin{array}{l}\text { Abdul Laifidamel } \\
\text { Croup }\end{array}$ \\
\end{tabular} & Retail & Massachusetts Institute of Technology \\
\hline Dr. Abdulanhman Al Zamil & Chaiman & 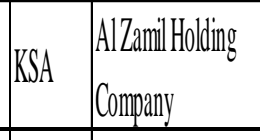 & Industry & University of Southem Califormia \\
\hline Bader M. AlSa'ad & Managing Director & \begin{tabular}{|l|l} 
Kuwait & $\begin{array}{l}\text { Kurvat Investment } \\
\text { Authonity }\end{array}$ \\
\end{tabular} & Finance & Miami Lnivesity \\
\hline Dr: Nasser Marafilih & CEO & Qatatar $\quad$ GatarTelecom & Telecoms & Geooge Washington University \\
\hline $\begin{array}{l}\text { Di: Khaled bin Abdulaziz Al } \\
\text { Ghoneim } \\
\end{array}$ & CEO & \begin{tabular}{|l|l|} 
KSA & $\begin{array}{l}\text { STC-Saudi } \\
\text { TelecomCompany }\end{array}$ \\
\end{tabular} & Telecoms & Cannegie Mellon Univesity \\
\hline Sultan Ahmed Bin Sulayem & Chaiman & UAE DPWorld & Industiy & Temple University \\
\hline Di: Sultan AlJaber & CEO and MD & UAE $\quad$ Masdar & Energy & $\begin{array}{l}\text { Coventry University, Califomia State University, University of } \\
\text { Southem Calfomia }\end{array}$ \\
\hline Ala'a Eraigat & CEO & \begin{tabular}{|l|l} 
UAE & $\begin{array}{l}\text { Abu Dhabi } \\
\text { Commercial Bank }\end{array}$ \\
\end{tabular} & Finance & Ceerge Washing gon University \\
\hline Mishal Kanoo & Deputy chaimanan & Balrain Kanno Group & Industiy & University of St. Thomass, Texas, American University \\
\hline Sheikha AlBhar & CEO & \begin{tabular}{|l|l|} 
Kuwait & National Bankof \\
Kuwwat
\end{tabular} & Finance & $\begin{array}{l}\text { Harrard Business School, Stanford University and Duke } \\
\text { University }\end{array}$ \\
\hline Maha Khalid Al-Ghunaim & $\begin{array}{l}\text { Chairperson and } \\
\text { managing director }\end{array}$ & Kuwait G GH & Finance & San Francisco State University \\
\hline Di. NaifAl-Mutawa & Founder and CEO & \begin{tabular}{|l|l} 
Kuwait & $\begin{array}{l}\text { Teshkeel Media } \\
\text { Croup }\end{array}$ \\
\end{tabular} & \begin{tabular}{|l} 
Culturue and \\
Society
\end{tabular} & Long Isand University, Coumbia University, Tutts University \\
\hline
\end{tabular}




\begin{tabular}{|c|c|c|c|c|c|}
\hline School Name & Level & Curriculum & School Name & Level & Curriculum \\
\hline Al Ameen School & $k-10$ & Arab, Islamic, UK & Dubai American ScientificSchool & $K-12$ & US \\
\hline Al Andalus School Dubai & $k-12$ & Arabic, US & Dubai Arab American School & $K-12$ & UAE/US \\
\hline Al Diyafah High School & $k-12$ & Indian, UK & Dubai British School & $K-12$ & UK \\
\hline A I Itihad Private School Jumeirah & $k-12$ & Arabic, US & Dubai British School Jumeirah Park & $K-12$ & UK \\
\hline Al Ittihad School Mamzar & $k-12$ & Arabic, UAE, US & Dubai Carmel School & $K-12$ & Arabic, UK \\
\hline Al Khaleej National School & $k-12$ & Arabic, UAE, US & Dubai College & secondary & UK \\
\hline Al Maaref Private School Dubai & $k-12$ & Arabic, UAE, US & Dubai English Speaking College & secondary & UK \\
\hline Al Mawakeb School & $k-12$ & Arabic, US & Dubai English Speaking School & primary & UK \\
\hline Al Mawakeb School Barsha & $k-12$ & Arabiclus & Dubai FirstSchool & $K-12$ & UAE, US \\
\hline Al Sadiq Islamic English School & $k-12$ & Arabic, UK & Dubai Gem School & $K-12$ & Indian/UK \\
\hline Al Salam Private School & $k-10$ & ArabicluK & Dubai International Academy & $K-12$ & UK/US \\
\hline Al Worood School Dubai & primary & Arabic, UK & Dubai International School & $K-12$ & Arabic, US \\
\hline American Academy for Girls Dubai & $k-12$ & US & Dubai International School Nad Al Sheba & $K-12$ & Arabic, US \\
\hline American International School Dubai & $k-12$ & Arabic, Canadian, US & Dubai Modem Education School & $K-12$ & UAE, US \\
\hline American School of Dubai & $k-12$ & US & Dubai National School & $K \cdot 12$ & UAE, US \\
\hline Apple Intemational School & primary & Indian/UK & Dubai National School Al Twar & $K-12$ & UAE, US \\
\hline Arab Unity School & $k-12$ & Arabic, UK & Dubai Scholars Private School & $K-12$ & Indian/UK \\
\hline Bradenton Academy Dubai & $k-12$ & US & Dubai School of Excellence & $K-12$ & US \\
\hline British Institute for Learning Development & $k-10$ & UK & Dubailand Taleem School & $K-12$ & UK, US \\
\hline British National Curriculum School & $k-12$ & UK & Dulwich College Dubai & & UK \\
\hline Cambridge High School Dubai & $k-12$ & Arabic, UK & DWCHighSchool & secondary & UAE, US \\
\hline Cambridge Intemational School Al Quoz & $k-12$ & UK & Ellesmere College Dubai & $K-12$ & UK \\
\hline Cambridge Intemational School Dubai & $k-12$ & UK & Emirates International Autism Center & & \\
\hline Cambridge Intemational School Dubailand & $k-12$ & UK & Emirates International School Jumeirah & $K-12$ & UK, US \\
\hline Cambridge Intemational School Jumeirah Village & $k-12$ & UK & Emirates International School Meadows & $K \cdot 12$ & UK \\
\hline Canadian International School Dubai & $k-12$ & Canadian & English College Dubai & $K-12$ & UK \\
\hline Capital School Dubai & $K=12$ & UK & English Medium School Dubai & $K=12$ & Arabic/UK \\
\hline Choueifat Dubai & $K-12$ & Choueifat, UK, US & Foremarke Hall School Dubai & primary & UK \\
\hline Choueifat Dubai Green Community & $K-12$ & Choueifat, UK, US & French School Dubai & & French \\
\hline Collegiate American School & primary & US & GEMS FirstPoint School Dubai & $K-12$ & UK \\
\hline Community West First School Dubai & primary & UK & GEMS Metropole School Motor City & $K \cdot 12$ & UK \\
\hline Deans Intemational School & $k-12$ & US & GEMS Wellington Academy Al Khail & & UK \\
\hline Deira International School & $K-12$ & UK & German Intemational School Dubai & $K-12$ & German \\
\hline Deira Private School & primary & UK & Horizon College Dubai & secondary & UK \\
\hline DPS Academy Dubai & $K-12$ & Indian & Horizon School Dubai & primary & UK \\
\hline Dubai American Academy & $k-12$ & US & Jebel Ali Primary School & primary & UK \\
\hline
\end{tabular}




\begin{tabular}{|c|c|c|c|c|c|}
\hline School Name & Level & Curriculum & School Name & Level & Curriculum \\
\hline Jebel AliSchool & secondar & UK & Raffles Intemational School South Campus & $k-10$ & UK, US \\
\hline JESS Arabian Ranches & $K-12$ & UK & Raffles Intemational School West Campus & $k-12$ & UK, US \\
\hline Jumeirah College & secondar & UK & Raffles World Academy & $K-12$ & UK, US \\
\hline Jumeirah English Speaking School & primary & UK & Rashid Primary School & primary & ArabiclUK \\
\hline Jumeirah International School & & & Rashid School for Boys & $K-12$ & ArabidUK \\
\hline Jumeirah Primary City School & primary & UK & RegentIntemational School & $k-12$ & UK \\
\hline Jumeirah Primary School & primary & UK & Repton School Dubai & $k-12$ & UK \\
\hline Juventus Soccer School Dubai & & Italian & Royal DubaiSchool & $K-10$ & UK \\
\hline K12International Academy & $K-12$ & US/Home School & Safa British Academy & $k-12$ & UK, International \\
\hline Kalimati Speech and Communication Center & & Arabic, English, French & Safa Community School & $k-12$ & UK \\
\hline KentCollege Dubai & & UK & SafaSchool & primary & UK \\
\hline Kings College Dubai & $K-12$ & UK & School of Modem Skills & $k-10$ & Arabic/US \\
\hline Kings School Al Barsha & $K-12$ & UK & School of Research Science & $K-12$ & Arabic, UK \\
\hline Kings School Dubai & primary & UK & Sharjah American School Dubai & $K-12$ & ArabicluS \\
\hline Kings School Nad Al Sheba & $k-12$ & UK & Sheffield School Dubai & $k-12$ & UK \\
\hline LatifaSchool for Girls & $K-12$ & UAE, UK & Silicon Oasis GEMSSchool & $K-12$ & UK \\
\hline Lycee Francais Intemational Dubai & primary & French & Sobha International Academy Dubai & $k-12$ & UK \\
\hline Lycee Francais Intemational Georges Pompidou & secondar & French & St Marys School Dubai & $K-12$ & UK \\
\hline Lycee Francais Intemational Meydan & primary & Arabic, English, French & Star International School Al Twar & $k-10$ & UK \\
\hline Lycee Georges Pompidou Ecole primaire Dubai & primary & French & Star International School Jumeirah & primary & UK \\
\hline Lycee Libanais Francophone Prive & $k-12$ & French & Star International School Mirdiff & primary & UK \\
\hline Millfield School Dubai & & UK & Sultan Al Owais Public School & & UAE \\
\hline Mirdiff Private School & K-10 & Arabic/US & Swedish School in Dubai & $k-12$ & Sweden \\
\hline Modern Renaissance School & primary & UK & Swiss International School Dubai & & Swiss \\
\hline Modern School and Nursery & primary & Indian/UK & The City International School & $k-12$ & Pakistan, UK \\
\hline National Charity School Dubai & $k-12$ & Arabic, UAE & The Oasis School Dubai & $k-12$ & UK \\
\hline New Arab Unity School & $k-12$ & Arabic, US & The Universal Academy of Excellence & $K-12$ & UK \\
\hline Nibras Intemational School & $k-12$ & Arabic/US & Universal American School & $k-12$ & US \\
\hline Nord Anglia International School Dubai & & UK & Victory Heights Primary School & primary & UK \\
\hline North American International School Dubai & $K-12$ & Arabic, US & Wellington Academy Dubai & $k-12$ & UK \\
\hline Omar Bin Al Khattab Model School & secondar & UAE, Arabic & Wellington College Dubai & & UK \\
\hline Ontario International Canadian School & K-12 & Canadian, Ontario & Wellington Intemational School & $k-12$ & UK \\
\hline Oundle School Dubai & $K-12$ & UK & Wellington Intemational School Palm Jumeirah & primary & UK \\
\hline Oxford School Dubai & $k-12$ & Arabic, UK & Wellington Primary School & primary & UK \\
\hline Pan American Academy Dubai & $K-12$ & Canadian & Westminster School Dubai & $k-12$ & ArabiclUK \\
\hline Pristine Private School & $k-12$ & UK & WinchesterSchool Dubai & primary & Indian / UK \\
\hline Queen International School & K-12 & Arabic/UK & Winchester School Dubai Oud Metha & & Indian / UK \\
\hline Raffles International School & $K-12$ & UK, US & & & \\
\hline
\end{tabular}




\section{References:}

1. Brown, H. (1983). Thinking about national security: Defense and foreign policy in a dangerous world (p. 107). Boulder, CO: Westview Press.

2. Calhoun, Craig and Georgi Derluquian, Eds. "Aftermath: A New Global Economic Order?” NYU Press, 2011.

3. Cox, Ronald. W. (Ed.). (2012). Corporate Power and Globalization in US Foreign Policy (Vol. 15). Routledge.

4. Davidson, C. (2013). After the Sheikhs: the coming collapse of the Gulf monarchies. Oxford University Press.

5. Field, M. (1984). The Merchants: The Big Business Families of Arabia. J. Murray.

6. Haggard, S. (1995). The political economy of democratic transitions. Princeton University Press.

7. Jones, T. C. (2012). America, Oil, and War in the Middle East. Journal of American History, 99(1), 208-218.

8. Mair, P. (2006). Ruling the void: The hollowing of western democracy. New Left Review, 42, 25-51.

9. McLean, D. (1976). Finance and "informal empire" before the First World War. The Economic History Review, 29(2), 291-305.

10. Potter, L. G. (Ed.). (2009). The Persian Gulf in History. Palgrave Macmillan.

11. Prashad, V. (2008). The darker nations: a people's history of the Third World. The New Press.

12. Robinson, W. I. (2001). Social theory and globalization: The rise of a transnational state. Theory and Society, 30(2), 157-200.

13. Robinson, W. I. (2001). Transnational processes, development studies and changing social hierarchies in the world system: a Central American case study. Third World Quarterly, 22(4), 529-563.

14. Robinson, W. I. (1996). Promoting polyarchy: Globalization, US intervention, and hegemony (Vol. 48). Cambridge University Press.

15. Robinson, W. I., \& Harris, J. (2000). Towards a global ruling class? Globalization and the transnational capitalist class. Science \& Society, 11-54. 
16. Robinson, William I. Transnational conflicts: Central America, social change and globalization. Verso, 2003.

17. Routh, Supriya (2011) "Building Informal Workers Agenda: Imagining 'Informal Employment' in Conceptual Resolution of 'Informality',' Global Labour Journal: Vol. 2: Iss. 3, P. 208-227.

Available at: http://digitalcommons.mcmaster.ca/globallabour/vol2/iss3/3

18. Schwartz, H. (2012). Political Capitalism and the Rise of Sovereign Wealth Funds. Globalizations, 9(4), 517-530.

19. Seymour Martin Lipset, The American Political Science Review, Vol. 53, No. 1 (Mar., 1959), pp. 69-105

20. Sklair, L. (1998). Transnational practices and the analysis of the global system (pp. pp-18). University of Oxford. Transnational Communities Programme.

21. Sklair, L. (2000). The transnational capitalist class and the discourse of globalisation. Cambridge Review of International Affairs, 14(1), 67-85.

22. Stokes, D. and Raphael, S. (2010). Global energy security and American hegemony. JHU Press.

23. Sultan, Nabil, David Weir, and ZeinabKarake-Shalhoub. The New Post-Oil Arab Gulf: Managing People and Wealth. Saqi, 2012.

24. Truman, E. M. (2008). Sovereign wealth funds: the need for greater transparency and accountability. Peterson Institute for International Economics.

25. Wade, R. H. (2008). Financial regime change?. New Left Review, 53, 5-21. 
Other Resources:

1. http://www.state.gov/r/pa/prs/dpb/2014/08/230777.htm

2. http://www.swfinstitute.org/fund-rankings/

3. http://www.dubaifaqs.com/schools-dubai.php

4. http://yaleglobal.yale.edu/content/globalization-and-middle-east-part-one

5. http://digitalcommons.fiu.edu/cgi/viewcontent.cgi $?$ article $=1010 \&$ context $=$ classraceco rporatepower

6. http://www.alpencapital.com/includes/GCC-Education-Industry-Report- September2010.pdf

7. http://www.arabianbusiness.com/destroy-all-churches-in-gulf-says-saudi-grandmufti-450002.html

8. http://www.jef.org.sa/files/EY\%20GCC\%20Youth\%20Perspectives\%20on\%20Empl oyment\%20JEF\%20Special\%20Edition\%202014.pdf

9. www.timeskuwait.com

10. worldbank.org

11. www.hrw.org

12. http://www.hrw.org/world-report/2014

13. http://graphics.eiu.com/upload/eb/GCC_in_2020_Resources_WEB.pdf

14. http://graphics.eiu.com/upload/eb/GCC_in_2020_Resources_WEB.pdf

15. http://www.thenational.ae/news/the-founding-sheikhs

16. http://www2.hn.psu.edu/faculty/jmanis/poldocs/uspressu/SUaddressJCarter.pdf

17. https://www.globalpolicy.org/component/content/article/162/27656.html 


\section{CHAPTER III}

THE FRAMEWORK FOR CONNECTIONS BETWEEN THE GCC TRANSNATIONAL ELITES AND THE TCC CONNECTIONS

\section{Introduction}

In this chapter, I analyze the relationship between GCC elites/states w it h in their own domestic and regional economies, and within the transnational capitalist class (TCC). I will examine the historical stages through which GCC transnational elites have established their positions within the TCC. I argue that the ascension of GCC elites/states to global power i s based on control of the upstream section of their oil industry. In 2013, GCC states produced 24 percent of global crude oil ${ }^{4}$. In terms of the ownership power in oil industry, the upstream section, which consists of economic activities revolving around exploration and production of crude oil is more important than the downstream section that involves marketing and distribution activities. After the nationalization of oil industries, GCC elites have been able to establish themselves as important actors in the TCC global network by controlling the upstream section of almost a quarter of global oil production.

The functional embeddedness of GCC elites/states in TCC is not, however, merely a result of the role of GCC transnational elites in global upstream oil section. GCC elites/states have also framed transnational states with an array of agents and actors that include, above all, the capitalist entities of other members of the TCC. In this chapter,

\footnotetext{
${ }^{4}$ Based on the data available here: https://www.middleeastmonitor.com/articles/middleeast/12302-the-oil-resources-of-the-gcc-states
} 
I will discuss the significant role of royal families, GCC conglomerates, powerful merchant families, and Sovereign Wealth Funds (SWFs) to shed some light on the network established by GCC elites/states within TCC. This will be analyzed in particular based on different characteristics of GCC capitalist network, including geographical connections, business connections, and family ties. This, in turn, will show that, contrary to widely held views, the embeddedness of GCC transnational elites in the TCC is broader than the GCC elites/states' role in the global oil industry.

In order to better comprehend the relationship between the GCC transnational elites and the TCC one must first understand to the structural position of the GCC in the global structure of accumulation, especially the role of oil - and to a lesser extent natural gas - in the global production network. The GCC is one of the crucial nodes of global oil supply. While the production of oil is a highly complicated process, I narrow the analysis in this chapter to an overview of the global oil production network that connects the GCC with oil firms outside the region. In that regard, it is useful to discuss the upstream and downstream oil activities as they involve the whole spectrum of exploration, development, production, refining and marketing, all of which connect the GCC elites directly to Western oil firms - which are engaged in refining, marketing and distribution of oil. The analysis of the upstream and downstream activities also allows us to examine where the oil profits made by the GCC elites eventually end up-i.e., the global financial and investment institutions where the interests of the GCC elites and the Western capitalist classes meet.

With respect to oil, one watershed moment in the political economy of the GCC was the "nationalization" of the oil industries. Although the GCC transnational elites may not legally own the oil resources, they have extensive powers over these resources. The 
powers of the GCC elites over oil are similar to the power and control the board members and high executives in the corporate world exert over corporate resources, even though these board members and executives too do not legally own the corporation under their control. The GCC states officially control the upstream oil activities, but the profits have flowed freely to the GCC conglomerates which have used these profits to expand their economic and political power throughout the region. Therefore the demarcation between GCC states and GCC private sector conglomerates is more artifice than reality.

\section{Nationalization of Oil and the Emergence of GCC Transnational Elites}

Nationalization did in fact increase the power of GCC elites vis-à-vis the multinational oil corporations in the upstream activities of global oil industry. Nationalization had resulted in a significant and prolonged period of conflict between the GCC states and the transnational oil firms who initially were threatened by nationalization. However, many of the IOC firms eventually adopted and profited from this new postnationalization relationship by focusing on control of downstream oil activities. This division of labor eventually led to cooperative ventures between the GCC states and the transnational oil corporations. Such arrangement has shaped after a period of heightened tension between the GCC states and the IOCs. The reason behind the uneasy transformation of GCC oil industries is the fact that during the 40s, 50s, and 60s, the so-called Seven Sisters controlled the whole chain of oil supplies, including the downstream and upstream activities. However, this unilateral dominant position came to an end in the 70s and 80s, partly as a result of nationalization movements in GCC states. The following table indicates the ownership structure of GCC oil industries before the period of nationalization. 


\begin{tabular}{|c|c|c|c|c|c|}
\hline & Aramo Sasudi Aadia & Kumaitoilco. & 0. Abuoldabi Pertoleum Co. & 0. Abuoldabi Marine Areass & Gathinan Petroleunco. \\
\hline Exxon & $30 \%$ & & $1188 \%$ & & \\
\hline Mobil & $10 \%$ & & $11888 \%$ & & \\
\hline Cheron & $30 \%$ & & & & $50 \%$ \\
\hline Texaco & $30 \%$ & & & & $50 \%$ \\
\hline Bitiths Pertoleum & & $50 \%$ & $23.57 \%$ & $60 \%$ & \\
\hline Gulf & & $50 \%$ & & & \\
\hline Shell & & & $23.75 \%$ & & \\
\hline Compagnilerananaisedes Petroles & & & $23.57 \%$ & $33 \%$ & \\
\hline Other & & & $5 \%$ & & \\
\hline
\end{tabular}

Table 8: Ownership of GCC Crude Oil Production Before Nationalization Source: http://modernhistoryproject.org/mhp?Article=FinalWarning $\& \mathrm{C}=8.4$

After nationalization of the GCC oil industries during the 70s and 80s, the GCC states became the "owners" of the oil facilities used for oil production. However, once nationalization took place in a GCC country, the International Oil Corporations (IOCs) were forced to move into a different level of oil industry, hence IOCs' focus on the downstream section and, in particular, on the process of oil delivery to refineries. Nationalization of oil industries resulted in a new business arrangement between the GCC elites/states and IOCs: GCC states became producers of oil and IOCs were now contracting with those states for marketing and distribution. The accommodation between the GCC states and the IOCs occurred, then, after a period of tension and opposition gave way to greater cooperation.

One significant historical episode that influenced the relationship between IOCs and NOCs in the GCC in particular was the Arab Oil Embargo. During that episode, and with the leadership of Saudi Arabia, many GCC states started to use oil as a political 
weapon. The consequences were so far-reaching and problematic for the GCC that it led to the realization among the GCC elites that use of oil as a political weapon is not an efficient policy in the long run. However, the episode facilitated the IOCs' recognition of the new and significant role of GCC states in their respective oil industries. Despite the fact that the Oil Embargo damaged Western economies, non-Arab producers such as Iran and Venezuela increased their production and eventually the global oil supply re-oriented in a way in which Western countries were ensured a reliable access to oil for the foreseeable future. It is noteworthy that, even though the Oil Embargo had been declared by Organization of the Petroleum Exporting Countries (OPEC), two of the funding members of OPEC-i.e. Iran and Venezuela- did not join the Embargo. In response to the Embargo, the IOCs established a network of concessionaries -both in downstream and upstream sectors- so that if one part of the network became inactive or blocked, the other parts could compensate. This new pattern proved to be quite successful as the recent instances show: when Iran and Iraq where under comprehensive economic sanctions, Saudi Arabia increased its production and made the global oil supply stable.

At the same time, however, GCC elites/states became fully conscious of the fact that they were powerful agents only through business cooperation within the TCC. On the other hand, the essential security umbrella for many GCC states and especially for the Saudi royal family heavily depend on U.S. support. In the case of Saudis, these ties go back as far as the agreement between President Roosevelt and Ibn Saud. Furthermore, the historical U.S. geostrategic ties to the GCC states was eventually accompanied by greater ties between the GCC elites and the TCC, an accommodation that followed the initial conflict and tension brought on by GCC nationalization. 
To sum up, nationalization of the GCC oil industries, the 1973 Oil Embargo, and the creation of OPEC created a new institutional arrangement in global oil industries where the IOCs lost their power as sole controller of oil prices and OPEC emerged as an important player. Furthermore, instead of disconnecting IOCs from GCC states, nationalization facilitated functional integration between IOCs and GCC elites in which the economic embeddedness of GCC bourgeoisie in TCC began. Meanwhile, the symbolic effect of the Oil Embargo on Western MNCs and the recognition of GCC's dependency on U.S. security support by GCC elites/states transformed the conflictual relationship between GCC and IOCs to a cooperative one.

The cooperative interaction between IOCs and GCC elites/states can be observed in both downstream and upstream sections. After the nationalization of oil industries, GCC elites/states became the sole owners and controllers of GCC upstream oil section. Unlike the ill-fated Iranian Oil Nationalization that ended up in the 1953 coup, Saudi Aramco made a gradual transition in its ownership that reduced the potential conflicts between Saudi Arabia and IOCs. At the beginning of the process of nationalization, the agreement between GCC states (such as Qatar or Saudi Arabia) and IOCs allowed the producing countries to take for instance 25 percent of the share in operations, "which would rise each year by five percent until it reached 51 percent [with compensation] paid to the companies...for the "adjusted book value" of the facilities, not for the oil resources." The companies would also assist in marketing the oil (Marcel, 2006, pp. 28-29). Today, however, in places like Kuwait and Saudi Arabia, the upstream section of oil industries are fully nationalized. The Saudi state-owned oil company, Aramco, has monopolized the upstream oil section in that country and replaced the two global giants that had engaged in 
the upstream section before, namely Shell and Total. With more than $\$ 7$ billion in revenue and some seven decades of experience in the Saudi oil sector,

Shell has been a particularly important factor in Saudi Arabia. Nonetheless, as a result of the monopolization of the upstream sector by Aramco, "Shell's efforts to become a part of Saudi's upstream oil segment have been frustrated and there are no signs of a dramatic near-term change in state policy" (BMI Company Analysis Reports, 4/2009, P. 1181, Lexus and Nexus).In other words, the GCC oil elites have been able to consolidate their control over the means of production in upstream sector of oil industries. The stateowned oil companies became a vehicle for protecting the private interests and for promoting the structure of capital accumulation for the GCC elites.

In terms of downstream oil industries, some former executives of IOCs became the board members of Saudi Aramco. For instance, the current board includes Sir Mark Moody-Stuart (former Chairman of Royal Dutch Shell), Peter Woicke (former Managing Director of the World Bank and Chief Executive Officer of the International Finance Corporation), and Andrew F. J. Gould (Chairman, BG Group plc). David Kultgen, the general counsel and corporate secretary of Saudi Aramco, is a U.S. lawyer, and has a key position in Saudi Aramco. According to Aramco's website, Kultgen "has concentrated on transactional and trade law. He participated as a member of the in-house negotiating teams responsible for several of the company's downstream joint- venture investments, both in Saudi Arabia and internationally, and was part of a Saudi Aramco team that supported the Ministry of Petroleum and Mineral Resources in the negotiation of energy-related issues 
during the Kingdom's successful accession to the World Trade Organization"5. Involving TCC members in Saudi Aramco and other parts of GCC oil industries made a harmonious shift oil industries possible in the aftermath of nationalization, as nationalization was replaced by gradual transnationalization and the further embeddedness of GCC elites within the TCC.

\begin{tabular}{|c|c|c|c|c|}
\hline & State Companies & Joint Ventures & Original Concession Holders & Major Foreign Oil Company Involvement \\
\hline Bahrain & $\begin{array}{l}\text { The Bahrain National } \\
\text { Oil Company } \\
\text { (BANOCO), wholly } \\
\text { orned by the Bahrain } \\
\text { Government, and is the } \\
\text { holding company for } \\
\text { the Bahrain Petroleum } \\
\text { Company (BAPCO) }\end{array}$ & 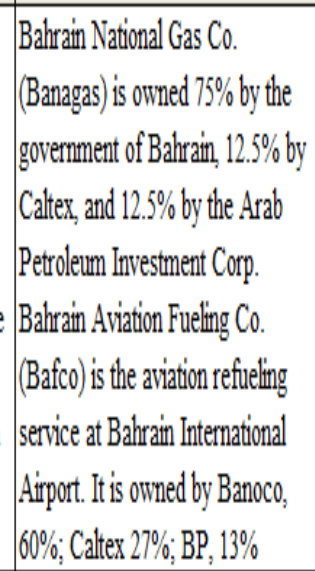 & 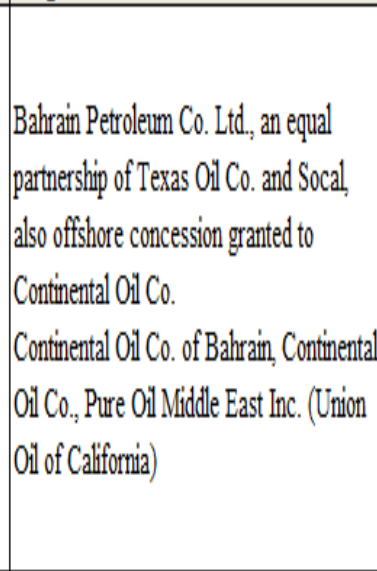 & $\begin{array}{l}\text { Harken OH, of Grand Prairie, Texas, who is } \\
\text { backed in part by Bass Enterprise Production } \\
\text { Company of Fort Worth, Texas Harvard } \\
\text { University, a major shareholder in Harken } \\
\text { through an afflitate, and George W. Bush }\end{array}$ \\
\hline Kuwrait & 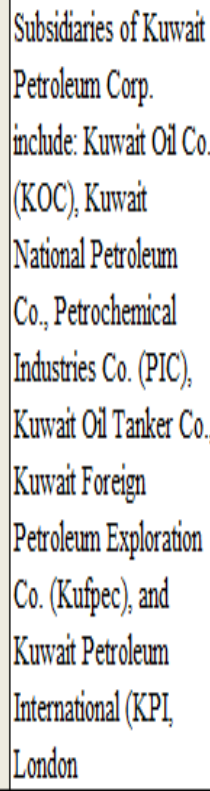 & & 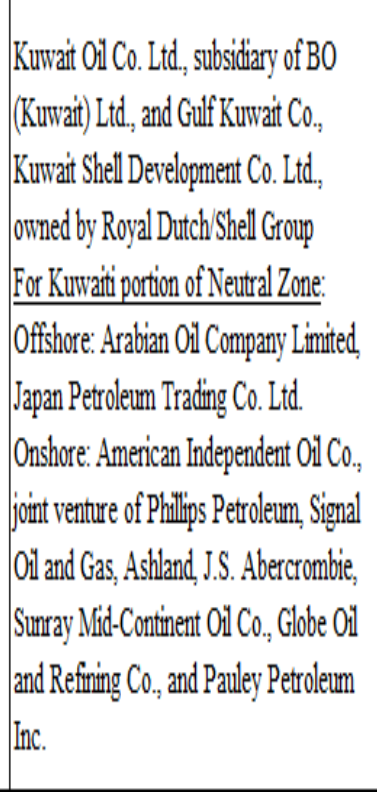 & 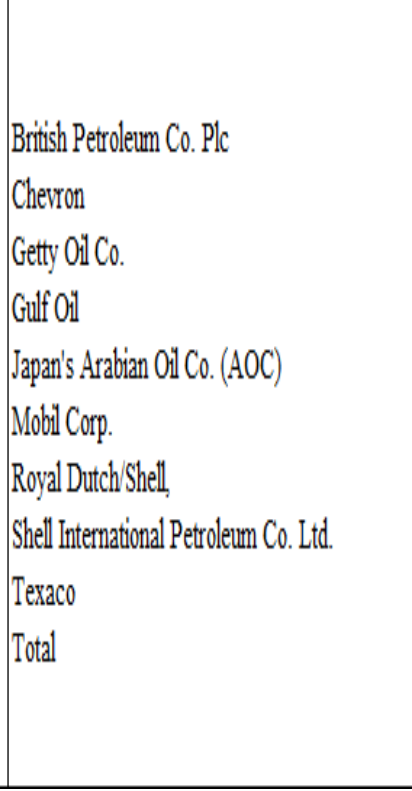 \\
\hline
\end{tabular}

${ }^{5}$ Borrowed from Saudi Aramco official website, available here:

http://www.saudiaramco.com/en/home/about/governance/leadership-team/david-b--kultgen.html 


\begin{tabular}{|c|c|c|c|c|}
\hline & State Companies & Joint Ventures & Original Concession Holders & Major Foreign Oil Company Involvement \\
\hline Oman & $\begin{array}{l}\text { Petroleum } \\
\text { Development Oman } \\
\text { Ltd. (PDO) controls all } \\
\text { oil resources. Oman O1 } \\
\text { Company (OOC) is the } \\
\text { overseas investment } \\
\text { arm of the Ninistry of } \\
\text { Petroleum, untl } \\
\text { recently headquartered } \\
\text { in Houston and headed } \\
\text { by John Deuss }\end{array}$ & $\begin{array}{l}\text { Petroleum Development Oman } \\
\text { Itd. (PDO) controls all oil } \\
\text { resources. PDO is a partnership } \\
\text { between the Omani government } \\
(60 \%) \text {, Shell Petroleum Co. Ltd. } \\
(34 \%) \text {, Total-CFP (4\%), and } \\
\text { Partex (Oman) Corp. (2\%) } \\
\text { CXO Ltd. Is a joint venture of } \\
\text { Oman OH Co. Ltd. and Caltex }\end{array}$ & $\begin{array}{l}\text { Petroleum Development (Oman) Ltd., } \\
\text { Shell Group, CFP, Participations and } \\
\text { Explorations Corp., and John W. Mecom } \\
\text { Mecom-Pure-Conoco, John W. Mecom, } \\
\text { Pure Oil, Continental Oil }\end{array}$ & $\begin{array}{l}\text { There are two American concessionaires: } \\
\text { Occidental/Gulf and Amoco. Ashland OI } \\
\text { manages Oman's sole refinery, and U.S. firms } \\
\text { lift Oman's crude. }\end{array}$ \\
\hline Qatar & $\begin{array}{l}\text { The Qatar General } \\
\text { Petroleum Corporation } \\
\text { (QGPC) }\end{array}$ & 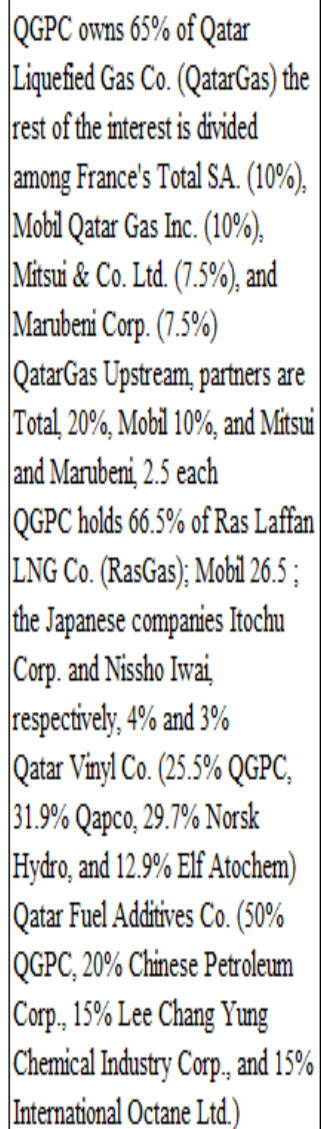 & 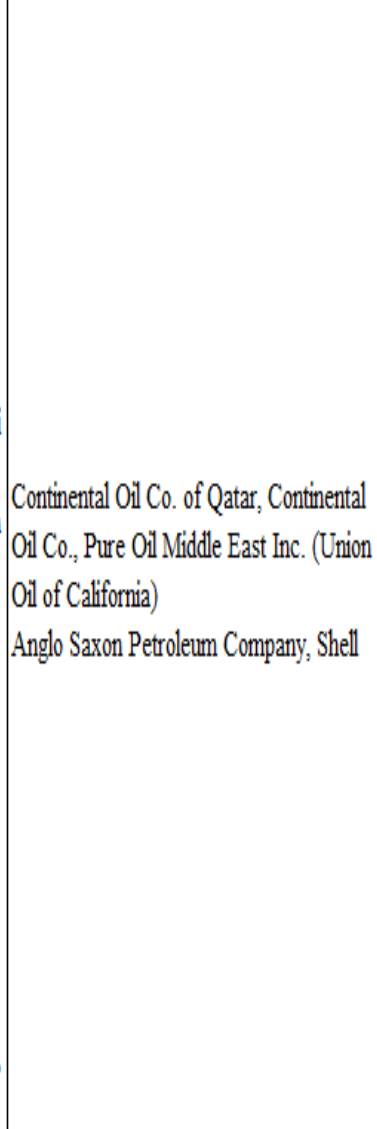 & 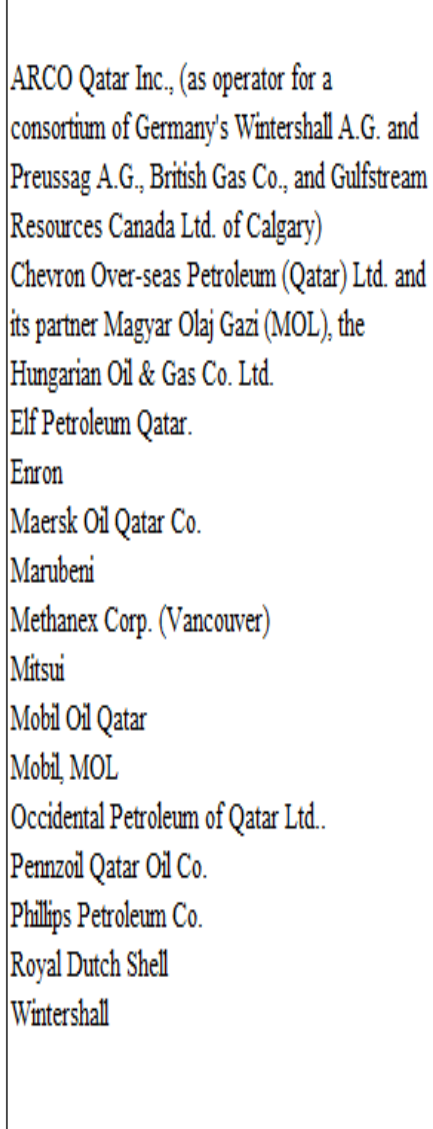 \\
\hline
\end{tabular}




\begin{tabular}{|c|c|c|c|c|}
\hline & State Companies & Joint Ventures & Original Concession Holders & Major Foreign Oil Company Involvement \\
\hline Saudi Arabia & $\begin{array}{l}\text { Saudi Aramco } \\
\text { Samarec } \\
\text { Petromin } \\
\text { Petromin Lubricating } \\
\text { Oil Refining Co. } \\
\text { (Luberef), [Mobil oil } \\
\text { Corp. holds a minority } \\
\text { interest in this } \\
\text { company] } \\
\text { Petromin Lubricating } \\
\text { Oil Co., } \\
\text { Saudi Arabian Basic } \\
\text { Industries (Sabic) }\end{array}$ & $\begin{array}{l}\text { Arabian American Oil Company, } \\
\text { Socal, Texas Oil, Jersey, Socony- } \\
\text { Vacuum } \\
\text { For Saudi portion of Neutral Zone: } \\
\text { Getty Oil Co., Japan Petroleum } \\
\text { Trading Co. }\end{array}$ & $\begin{array}{l}\text { Star Enterprise (U.S.) - Saudi Refining } \\
\text { Inc. (50\%), Texaco (50\%); } \\
\text { Ssangyong 01 Refining Co. (S. Korea) - } \\
\text { Saudi Aramco (35\%); Ssangyong (65\%); } \\
\text { Luberef- Mobil (30\%) and Petrolube - } \\
\text { Mobil (29\%) } \\
\text { Samref, an export fuels company- Mobilis } \\
\text { a 50\% shareholder } \\
\text { Subsidiaries: Aramco Services Co. } \\
\text { (Houston), Aramco Overseas Co. } \\
\text { (Netherlands), Saudi Petroleum } \\
\text { International Inc. (New York), Saudi } \\
\text { Petroleum Overseas Ltd. (London'Tokyo) }\end{array}$ & Mobil \\
\hline UAE & $\begin{array}{l}\text { Abu Dhabi National O1 } \\
\text { Company (ADNOC) } \\
\text { has controlling interest } \\
\text { in } 21 \text { domestic oil and } \\
\text { natural gas companies. } \\
\end{array}$ & 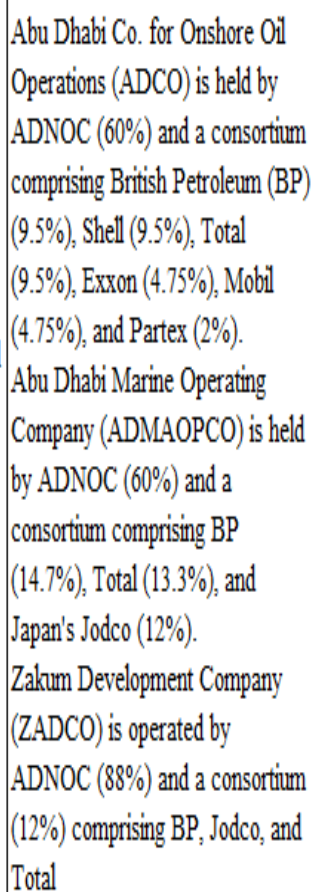 & 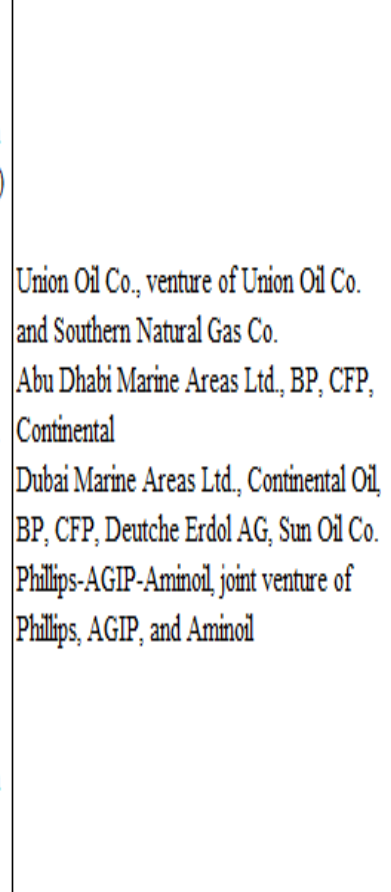 & $\begin{array}{l}\text { BP } \\
\text { Caltex Petroleum Corp., } \\
\text { Mintsui \& Co. Ltd. } \\
\text { Parrex } \\
\text { Pennzoll } \\
\text { Shell Gas BV } \\
\text { Total }\end{array}$ \\
\hline
\end{tabular}

Table 9: International Oil Corporations (IOCs) in GCC Source: Based on the information available here:

http://www.virginia.edu/igpr/APAG/apagoilcompany.html 
Unlike the upstream section in which GCC states/elites became significant players in the global oil industry, the downstream of the global oil industry is still dominated by IOCs. In addition to the strong network in marketing and distribution that had been established by the Seven Sisters, the technological advantage of IOCs over national oil industries gave them the upper hand in downstream oil industries. In the GCC, and through several joint ventures and concessionaires in the downstream section -which include marketing and refinery sections, IOCs have been the main economic actors. Table 9 indicates just a few important business involvements of IOCs in the GCC.

The IOCs' activities have been limited to the downstream part of the oil industries. Saudi Arabia's dependency on IOCs is still part of the picture, although the giant Saudi Aramco has now started investing in the downstream section as well. Nevertheless, the GCC oil industry constitutes a relatively small portion of the global downstream oil industry. In the transportation sector, which is considered a mid-stream sector, Saudi Arabia and Kuwait currently have three large tanker operators that are among the top 30 tanker transporters in the world: Vela International Marine (Saudi Arabia), National Shipping Co of Saudi Arabia, and Kuwait Oil Tanker Co (Inkpen \& Moffett, 2011, P.427).

All in all, the GCC states are not major actors in the global downstream oil industry. The refinery capacity of Saudi Arabia only consists of 2.9 percent of the total global refinery capacity. Kuwait has only 1 percent and the UAE 1.20 percent of the total global refinery capacity while the U.S. stands at 18.4 percent and China controls 14.6 percent of that capacity (BP Statistical Review of World Energy June 2015, P. 16). Meanwhile the GCC downstream section depends heavily on the technological assistance and skilled workers (and mainly engineers) of foreign firms. Without these joint ventures, GCC states 
are arguably unable to continue their downstream activities by relying merely on their indigenous capabilities.

The new economic ties between the GCC elites and the TCC transformed the oil nationalization movement from a "threat" to the global oil industry to an "opportunity" for foreign capital and the further integration of the GCC into the transnational class. From the 1980s onwards, by controlling the upstream sector of oil industries the GCC elites were able to expand their business activities to other sectors and to create GCC-based conglomerates. Nearly all these conglomerates depend on the support, skill, and technology of the broader global business network controlled by the TCC. Today, these conglomerates are crucial nodes of TCC capital accumulation. More importantly, many economic activities that are considered as state economic activities are performed by these conglomerates. This arrangement closely relates to the rentier characteristics of these states or in Hanieh's words: "The Gulf capitalist class has emerged rapidly and in "hothouse" fashion - from state-supported and family-based trading groups in the 1960s and 1970s to the domination of a few massive conglomerates in the contemporary period" (Hanieh, 2011, P. 2). The following part of this chapter will analyze the process by which GCC capital penetrated other sectors of both the GCC economies and the global economies. In turn, the economic ties between the GCC transnational elites and the TCC have grown stronger and more complicated than before.

\section{Forces of Production}

In the following, I will discuss the dominant forces of production within the structure of capital accumulation in the GCC. The previous parts of the dissertation dealt with the fact that oil has been central to the "global structure of accumulation" for the GCC 
capitalist states. This section focuses on the penetration of GCC capital to other types of economic activities in order to show the interconnectedness between the GCC capitalists, both within themselves and also with the TCC. Such interconnectedness is a pre-condition for the cohesion of the GCC capitalist class. In turn, this interconnectedness is the manifestation of the emerging role of GCC elites/states in the centralization of global capital accumulation by TCC through transnational economic practices.

Oil is clearly a significant commodity in relation to global class struggles. In particular, two impacts of oil should be taken into account. On the one hand, the GCC is the "largest producer as well as exporter of petroleum and plays a leading role in the world in general and OPEC in particular" (GCC Economic Overview, Gulfbase.com). On the other hand, as the following chart indicates, the national revenues of the GCC countries heavily depend on oil and natural gas resources.

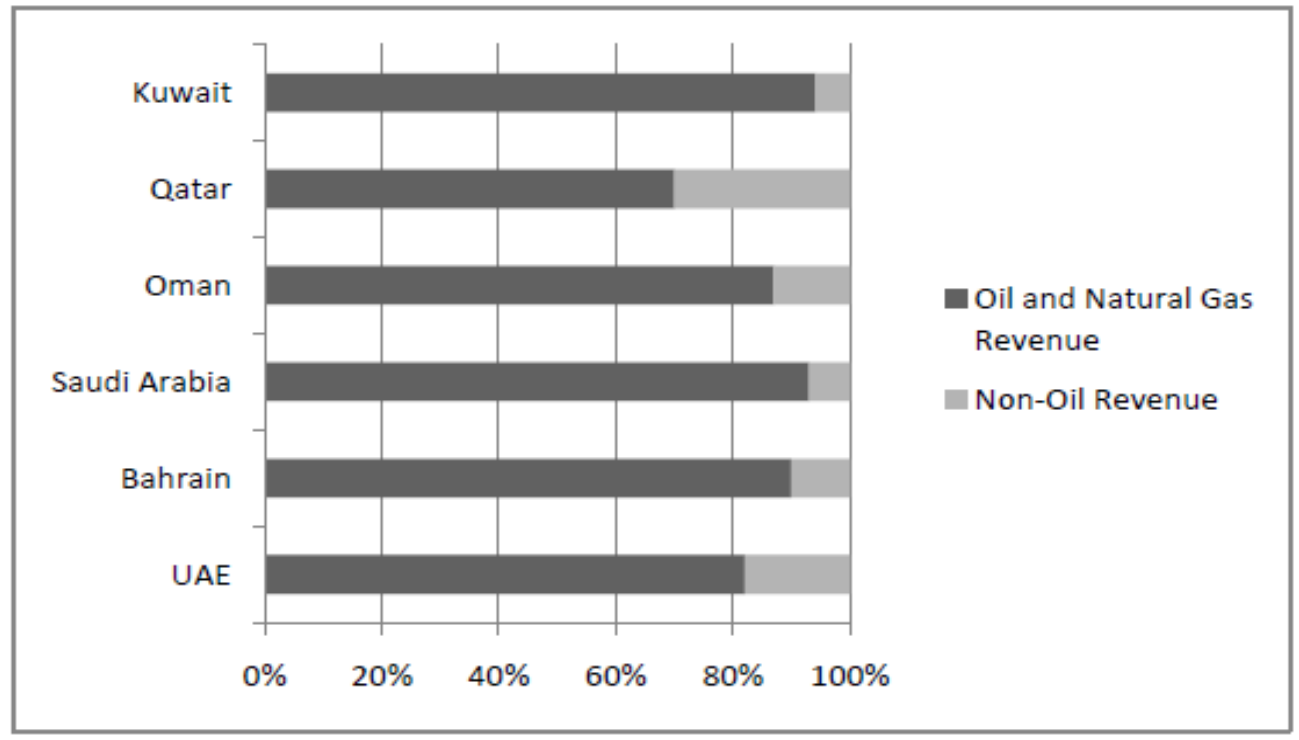

Chart 2: gulf States are increasingly_and almost completely_dependent on oil revenues for their national budgets Source: Borrowed from: https://www.gulfpolicies.com/media/files/Khaleej_2013_Grand_Research_Final.pdf (P.99, In Arabic) 
From the 1970s onward all the GCC states have earned large amounts of petrodollar surplus. Given the magnitude of these surpluses, the GCC states have not been able to invest or spend them within the GCC. In turn, the GCC elites started investing in other economic opportunities. The two major economic sectors that the GCC elites engaged in have been the construction industry and the global financial sector. Up until the end of 2009, the GCC state- owned construction companies had been involved in 87 megaprojects - projects worth $\$ 150$ million or more - within the GCC but not in their home country, 40 of which involved "pan-GCC Groups." These 40 projects involving pan-GCC groups account for 75 percent of the total project value. In this mode of GCC capital accumulation, the UAE arguably plays the most active role given the number of its construction projects (Hanieh, 2011). Meanwhile, the construction industry manifests the struggles within regional classes. In other words, these kinds of investments have been growing through increasingly complex economic ties among the GCC- based elites rather than through the relationship between the GCC elites and TCC. Therefore, the construction industry manifests the cohesion among the members of the GCC capitalist class. However, in many sectors within the construction industry such as communications, IT services, final products, and professional engineering skills the whole GCC construction industry depends on the technological support of Western multinational corporations. Unlike the oil supply system, the GCC construction industry is not an important node for global capitalism. Nevertheless, with the UAE's crucial role in the construction industry and the Saudis in oil industry, "[The Persian Gulf] Capital is hierarchical-structured around a Saudi-UAE axis, with other capital connected in a subordinate fashion to this core" (Hanieh, 2011, P. 2). 
In addition to the revenues from the construction industry the oil revenues have opened another venue for the GCC capitalist class to accumulate profit. This in turn has furthered the financialization of the GCC political economy. This financialization and the financial activities of the GCC transnational elites are more consequential, as far as this research is concerned, than the GCC construction industry because, unlike the construction industry that has increased the regional cohesion within the GCC elites, the financial activities often revolve around the economic ties between the GCC elites and the TCC. As will be discussed in the following parts, the construction industry is controlled by a network of merchant families close to the royal families. When it comes to the transnational financial activities, however, the main actors are members of the royalty.

\section{Transnationalization of GCC States}

This section of the chapter aims at analyzing the nature of the relationship between GCC elites, GCC states and GCC conglomerates. GCC states undertake rentier activities but also engage in many transnational capital accumulation activities that are vital for global capitalism. The structure of the 'state' in the GCC is not separate from the socioeconomic structure of the GCC bourgeoisie. In order to better understand the position in this structure of GCC merchant families (who are an extension of GCC royal families), it is essential to consider the notion of a transnational rentier state. The term transnational rentier state used in the previous chapter to describe the GCC states is in part meant to disclose the structural weaknesses of the institutional settings in the GCC countries. Explaining the GCC states only based on their rentier characteristic, however, may lead to an unwarranted analytical leap. One commonly cited understanding of the notion of rentier state in the Arab world is suggested by Hazem Beblawi that "the state or the government, 
being the principal rentier in the economy, plays the crucial role of the prime mover of the economic activity" (Beblawi, 1987, P. 386). Beblawi does not reject the role and existence of a "ruling class" when he introduces the notion of a rentier class that controls the wealth of the rentier state. However, Beblawi appears to reduce the notion of rentierism to a social function. In contrast, while I do not reject the rentier characteristic of GCC states, I argue that rentierism does not explain all the key characteristics of states in the GCC. In particular, one must understand the whole structure of rentierism in association with the demand of the GCC bourgeoisie for securing the process of capital accumulation. In order to achieve that goal, the GCC transnational elites need a secure transnational space for transnational capital accumulation. The result is a particular form of transnational rentier states.

There is, of course, a 'rentier class' in the GCC. This class is maybe best understood by viewing it as a transnational rentier class with its interests more based on transnational practices rather than on traditional state-centric economic activities. This transnational rentier class is the primary shaper and mover of the GCC economic structure. The social structure that Beblawi focuses on is merely a reflection of the economic structure of material production of GCC transnational elites. In other words, it is above all the dynamics of capital accumulation by the GCC transnational elites that determines the social, political, and economic systems of GCC. From the 1970s onwards, many smaller businesses that had interaction with the oil industries merged together and became a conglomeration of business networks. This process in the GCC has led to a fast growth of construction and service firms that are naturally the extension of the GCC elites' capital accumulation based on the considerable surplus value of oil revenues. These radical capitalist expansions in 
turn have changed the balance of power among different players in the GCC and today the global conglomerates are part of the GCC ruling system, as Adam Hanieh sharply puts it:

"The Gulf capitalist class has emerged rapidly and in "hothouse" fashion-from state- supported and family-based trading groups in the 1960s and 1970s to the domination of a few massive conglomerates in the contemporary period. Most significant-and the key characteristic of the region's political economy examined in this book - is the pronounced internationalization of Gulf capitalism over the past decade. Large Gulf conglomerates now conceive their profit-making activities across the entire GCC rather than solely within its individual memberstates. They own stakes in a wide variety of industrial, financial, and retail firms located throughout the region." (Hanieh, 2011, P. 2)

The following table includes some important GCC conglomerates that perform a variety of economic activities. In a number of scholarly works, and especially those based on the rentier school of economics, these economic activities are simply considered state economic activities. There is some evidence to support such a view. Most importantly, almost all these conglomerates are owned and controlled by the members of the GCC transnational elites - the same network that also created states to protect and promote its own interests. However, it may be oversimplifying to ignore the rising corporate power in the political economy of GCC. To provide some perspective with respect to this corporate power, Table 10 shows ten conglomerates in GCC that monopolized many aspects of GCC economy. 


\begin{tabular}{|c|c|c|c|}
\hline Conglomerates & Country of Origgin & Main Activities & Locations and Offices \\
\hline Fakhro Group & Balrain & $\begin{array}{l}\text { Motoos, Transpoot, Restaurants, Company, Electronics, Commurications, } \\
\text { Commercial and Insurance services }\end{array}$ & Balrain, Iraq, the UAE, and Incia \\
\hline Kanoo Group & Balrain & 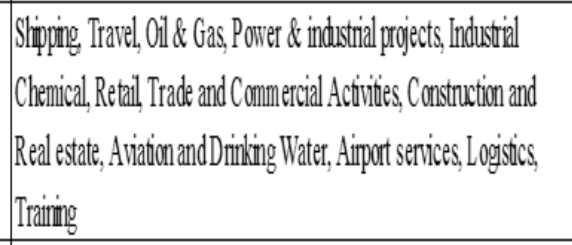 & $\begin{array}{l}\text { Balrain, Kingdom of Saud Arabia, } \\
\text { United Arab Emirates, Oman, Qatar, } \\
\text { Egypt,United Kingolom, France, India }\end{array}$ \\
\hline Aljazeera Wedia Netrook & Qatar & Media & $\begin{array}{l}\text { Americas, Europe, Sub-Saharan Affica, } \\
\text { Middle East, Noth Africa, Asia Pacific }\end{array}$ \\
\hline Dallah AtBaraka & Saud Arabia & $\begin{array}{l}\text { Trade, Real Estate, Operaboon \& Services, Financial Services, } \\
\text { Transportation, Heathcare,Food Industry, Media, Investment }\end{array}$ & Asia, Viddle East, North Africa, Europe \\
\hline Kingdom Holding & Saud Arabia & 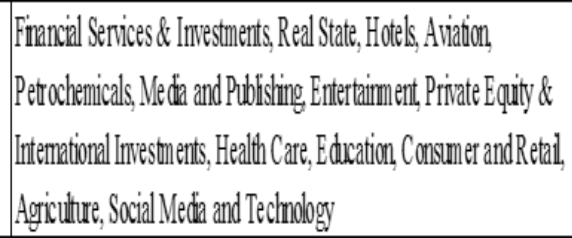 & $\begin{array}{l}\text { Saudi Arabia with tens of subsidaries } \\
\text { around the wotld. }\end{array}$ \\
\hline SABIC & Saudi Arabia & $\begin{array}{l}\text { one of the world" sleading manfifactureers of chemicals, fertilizers, plastics } \\
\text { and metalls. }\end{array}$ & $\begin{array}{l}\text { smericas, Europo, Wididle East, Noth } \\
\text { Africa, Asia }\end{array}$ \\
\hline Saudi Binladin Group & Saudi Arabia & Power, Constuction, Industrial Constuction & $\begin{array}{l}\text { Saudi Arabia, Oman, UAE, Egyph, } \\
\text { Letannon, London }\end{array}$ \\
\hline AlFuttaim Group & United Arab Emirates & $\begin{array}{l}\text { Automotive, Retaling, Electronics, Engineerning and Tectmologes, } \\
\text { Fimance, Genereral Sertices, Real Estate and Constuction }\end{array}$ & $\begin{array}{l}\text { UAE, Bahrain, Kurvat, Oman, Qatar, } \\
\text { Saudi Arabia, Egypt, Pakistan, SriLanka, } \\
\text { Syina, Singapore and Europer }\end{array}$ \\
\hline AlGhunir Group & United ArabEmirates & Industrial, Real Estate, Investments & $\begin{array}{l}\text { UAE, GCC, Middle East and Noth } \\
\text { Aficica, Europe, Asia, Australla, Sorth } \\
\text { America }\end{array}$ \\
\hline Dubail World & United Arab Emirates & 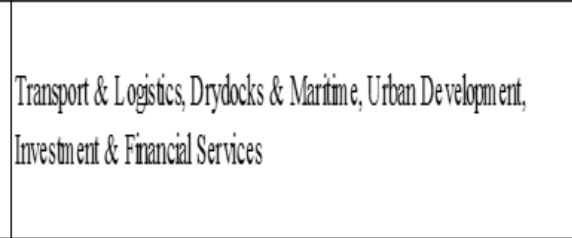 & $\begin{array}{l}\text { UAE, New York, London, and Cape } \\
\text { Town It has operationsin the Americas, } \\
\text { Aficica, the Vidide East, Asia, and } \\
\text { Elurope. }\end{array}$ \\
\hline
\end{tabular}

Table 10: Important GCC Conglomerates and their Activities Source: The Official Websites of Each Conglomerate

The above conglomerates are in essence capitalist agencies that maintain two kinds of social relations: they interact with the GCC capitalist class and connect the GCC transnational elites to TCC. For instance, the Fakhro Group, which is owned by Fakhro 
family of Bahrain, has business arrangements with such global corporate players as Dongfeng Motor Corporation (a Chinese giant corporation), McDonalds, LG, Sony, OKI, Ericsson, Budget, Avaya, Aastra, Softex, MK Electric Co., Brand Rex Ltd., Morley IAS, Honeywell, ABB, GAC logistics, and Mobil ${ }^{6}$.

As another example, the Kanoo International Property Broker's main economic activity is to provide services for global consumers who are purchasing properties with the "specific focus on the UK."7 One subsidiary of the Kanoo group, also based in Bahrain, is Maersk Kanoo, which serves as agent for Maersk group, a Danish conglomerate represented by Kanoo group in the GCC. The globally oriented approach of Kanoo is evident on their website, which states "[m]ainline services from the United States, Europe and the Far East call at Jebel-Ali port every week. The port serves as a transit point for the Middle East and is a dedicated feeder network that offers coverage to all ports in the Gulf."8 In its Arabian Equipment Rentals enterprise, Kanoo Group has partnership with Sykes group in the United States. The largest insurance company in the GCC, AXA Gulf Insurance, is a subsidiary of Kanoo group. This company is also a part of the overseas operation of the French multinational corporation, AXA. Dallah group, which was established by the Kamel family, is known as an "Islamic conglomerate." It engages in many Islamic economic and financial activities including Islamic banking and Islamic insurance. In terms of economic activities, Dallah is one the most diversified

\footnotetext{
${ }^{6}$ http://www.fakhro.com/

${ }^{7}$ http://kanoo.com/partners/kanoo_property.aspx

${ }^{8}$ http://kanoo.com/partners/maersk.aspx
} 
conglomerates in the region. Another conglomerate in the region belongs to the Bin Laden family, which is one of the merchant families in Saudi Arabia closest to the Royal Court. Given the atrocities and devastations that Osama Bin Laden, a member of this family, caused in the Muslim world and in the West, it is not surprising that controversial claims and allegations have been leveled against the Bin Laden conglomerate. Some maintain that the family has had secret ties with the Western capitalist class despite its continued support for Osama Bin Laden. The terrorist attacks of 9/11 shed some light on some of the family's previously quiet business ties. For instance, on October 26, 2001, Kurt Eichenwald published an article in the New York Times, entitled "Bin Laden Family Liquidates Holdings With Carlyle Group." The article states that, "the Saudi family of Osama bin Laden is severing its financial ties with the Carlyle Group, a private investment firm known for its connections to influential Washington political figures...."9 This action was probably taken in response to the $9 / 11$ attacks.

The Al-Ghurair group, based in the UAE, has spread its economic activities in four continents and around twenty countries. Its economic activities include such diverse sectors as "Foods, Construction, Resources and Properties, with additional sector participation in Energy, Printing, Retail and Education."10

Jafza, a subsidiary of Dubai World group, "is a dynamic base for thousands of businesses, from over 100 countries, sustaining over 135,000 jobs and attracting more than

\footnotetext{
${ }^{9}$ http://www.nytimes.com/2001/10/26/business/bin-laden-family-liquidates-holdings-with-carlylegroup.html

${ }^{10} \mathrm{http} / / /$ www.al-ghurair.com/en/the-group/
} 
$20 \%$ of the UAE's foreign direct investment; all the while exceeding $50 \%$ of Dubai's total exports, with a phenomenal value for trade of $\$ 69$ billion." 11

The Al-Futtaim family from the UAE has an interesting history. The family's business was struggling during the 1940s and 1950s. At the time it had certain political conflicts with Al-Makoutm family, the ruling family of Dubai. The conflict resulted in the exile of Hamed al-Futtaim, a prominent member of the family. However, they later managed to regain their economic position by cooperating with the al-Maktoum family.

Al-Futtaim Private Company LLC, through its subsidiaries, owns and operates commerce, industry, and services businesses. It uses a network of showrooms to distribute passenger and commercial vehicles manufactured by Toyota, Lexus, Hino, Honda, Volvo, Chrysler, Jeep, and Dodge. It also sells construction equipment, and provides used car sale, rental, and leasing services. The company distributes Panasonic, Toshiba, Sanyo, and AFTRON products that are offered through a network of re-sellers, mass merchandisers, channel partners, and retail outlets of branded stand-alone stores. It provides solutions to the building and construction industry in the UAE and lower Gulf region. Additionally, the company represents retail brands including Marks \& Spencer, IKEA, ACE, Toys "R" Us, and Intersport, as well as offering fashion, sportswear, watches, and jewelry products through a network of its retail outlets. The company also serves investment banking, equity broking, and fund management sectors through specialist companies, joint ventures, and associations. Its logistics, travel, advertising, training, IT and systems, ship and rig repair, and materials -testing services support the company's core business verticals. It

\footnotetext{
${ }^{11} \mathrm{http} / / /$ jafza.ae/about-us/our-history/
} 
also offers development, procurement, construction, and leasing services for real estate projects. The company was formerly known as Al-Futtaim Group. Al-Futtaim Private Company LLC is based in Dubai, United Arab Emirates. ${ }^{12}$

The above examples of conglomerates are all owned by prominent Arab families, some of which are themselves members of the royal families; the rest are connected to GCC royal families. For instance, the chairman of Kingdom Holding Company, Prince alWaleed Bin Talal, who is dubbed "the richest Arab in the world," is the grandson of Ibn Saud, the founder of Saudi Arabia. Likewise, the chairman of Dubai World is Ahmed bin Saeed Al Maktoum, who is the uncle of the ruler of Dubai, Mohammed bin Rashid Al Maktoum. As Figure 1 demonstrates, the merchant families who control the significant GCC conglomerates have economic or family ties with the GCC royal families. The black lines in the Figure represent familial ties.

${ }^{12}$ http://www.bloomberg.com/research/stocks/private/snapshot.asp?privcapId=13011365 


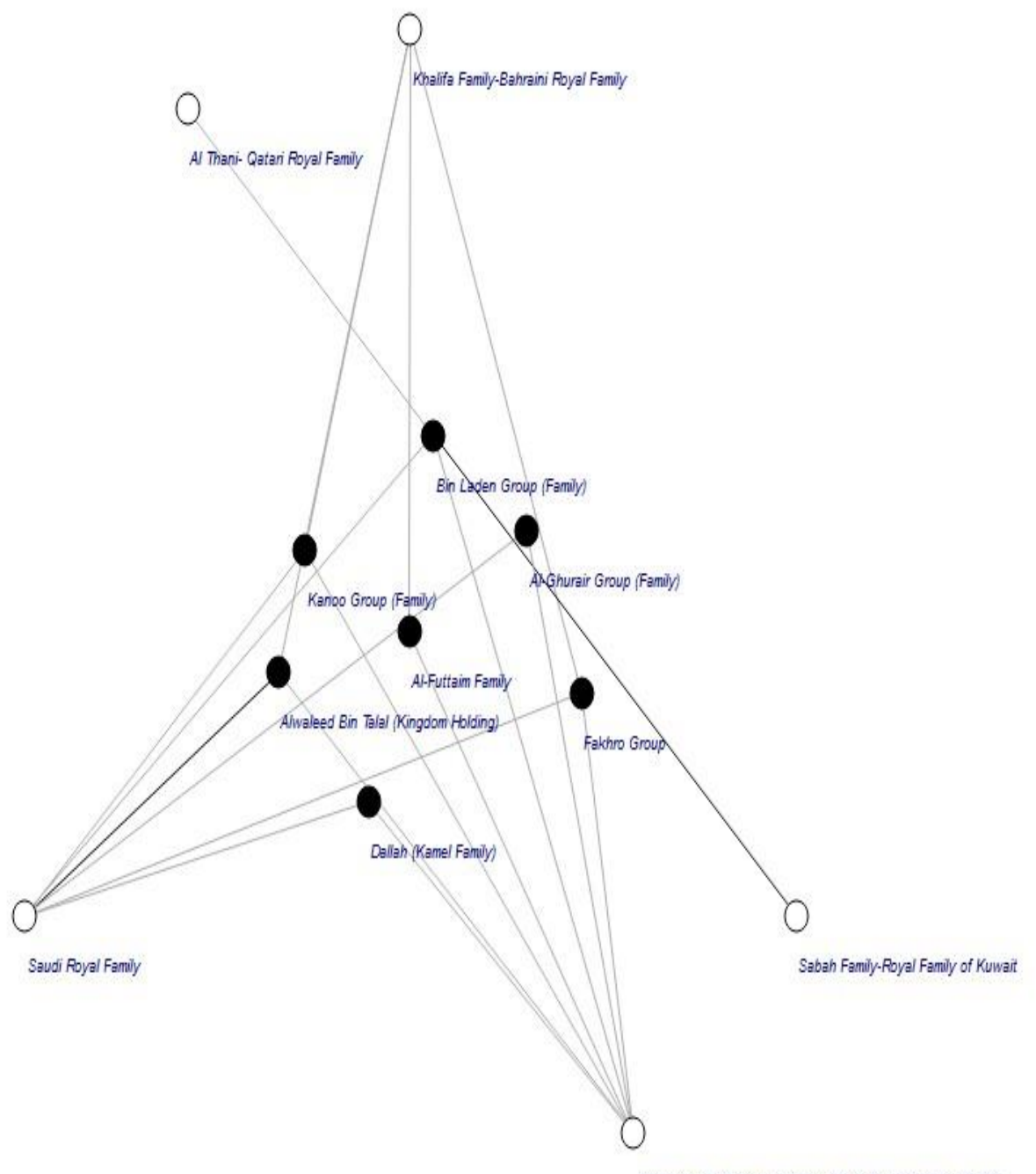

Al-Nahyan \& Maktoum Famīies, Major Royal Families of UAE

Figure $4^{13}$ : The Economic and Family Ties Between Merchant Families and Royal Families in GCC

Sources: Based on data and information in the websites of mentioned conglomerates, business press, and scholarly resources ${ }^{14}$

\footnotetext{
${ }^{13}$ Most probably there are more connections than the figure is indicating. These connections are based on the reliable resources and sufficient to indicate the fact that GCC economy is merely a family business, controlled by GCC capitalist class.

${ }^{14}$ Rush, Alan. Al-Sabah: History \& Genealogy of Kuwait's Ruling Family, 1752-1987. Garnet \& Ithaca Press, 1987. Hertog, S., Luciani, G., \& Valeri, M. (Eds.). (2013). Business politics in the Middle East. Hurst Publishers. Sabri, S. (2001). The House of Saud in commerce: A study of royal entrepreneurship in Saudi Arabia. Sharaf Sabri. Gause, F. G. (1994). Oil monarchies: domestic and security challenges in the Arab Gulf states. Council on Foreign Relations.
} 
The above network indicates the economic and familial ties between the GCC merchant families, who control the GCC conglomerates, and the GCC royal families. The network does not include the economic and familial ties within the GCC royal families and the similar ties within the merchant families. In fact, there are many economic and familial ties within the GCC royal families that are rooted in the old relationships between the ruling tribes in the Arabian Peninsula. For instance, the Saudi ruling family of Aal Saud, the ruling Al- Sabah family of Kuwait, and the ruling Al-Khalifa family of Bahrain all "belong to Onaiza tribe and have originated from the central part of the Nejd" (Sabri, 2001, P. 22). Some of the key merchant families are connected to each other through both economic and familial ties:

"The Hijazis merge[d] with. . .the non-Arabian. . immigrants. These people are Hindus and Indian Muslims, Persians and Hawala - 'wonderers.' The members of the last group are Sunni Muslims who left Arabia several hundred years ago, lived in Iran and became partly Persianised and have since returned to the Arabian side of the Gulf. Needless to say the Hawala, who include the Kanoo, Almoayed and Fakhroo families of Bahrain, are nowadays at pains to the brevity of their stay across the water. They are regarded by all parts of the population as being very much more Arabian than the other long- standing immigrants". (Field, 1984, P. 75)

Generally speaking, the religious belief and tribal background of important families determine their position in the hierarchy of political and economic power in the GCC. For instance, the Sunni background of such groups as Kanoo and Fakhro has helped them to establish their business position in Bahrain. Interestingly, the majority of Bahrainis are 
Shia, but the ruling family is Sunni. It is true that the merchant families that control the GCC conglomerates have limited influence on politics. However, they have sufficient access to the royal families based on economic or family ties to become important part of GCC capital accumulation.

The above-mentioned conglomerates also connect the GCC capitalist class to TCC. The generous financial and political support of the GCC royal families facilitated the growth of interconnectedness between GCC conglomerates and other markets all around the globe. Figure 5, which is based on Table 9 above, clarifies the geographical interconnectedness. ${ }^{15}$

\footnotetext{
${ }^{15}$ For more details on GCC conglomerates economic ties with multinational and transnational corporations see the Appendix.
} 


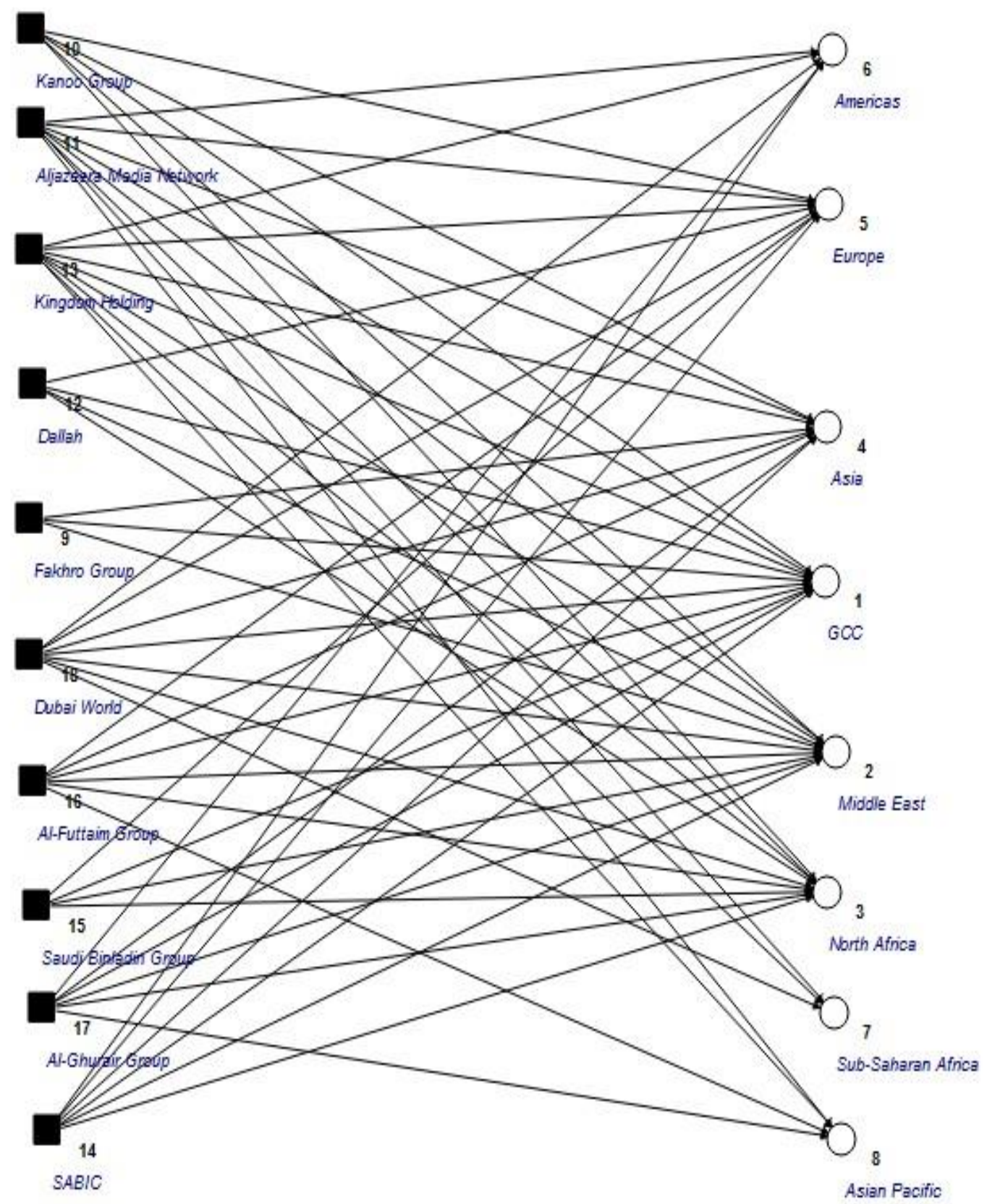

Figure 5: The Geographical Networks of GCC Conglomerates Source: Based on Table 1 


\section{The Financial Power of the GCC Elites}

The GCC's recent state of political economy suggests a growing tendency within the GCC elites to promote economic diversity beyond oil - in particular, they seek to develop the financial sector of GCC capitalism. Although oil remains the lynchpin, the clear preference is now the global investment sector. The GCC elites have invested their wealth in a wide variety of businesses and with other dominant capitalist actors. Overaccumulation along with financialization have resulted in new and strong ties between the GCC transnational elites and the TCC.

These new economic ties have resulted in the dramatic expansion of local bourgeoisie who are quite powerful on the regional level. The previous section discusses how the GCC conglomerates strengthen the economic ties between the GCC bourgeoisie and multinational corporations. One result has been the growth of local, regional conglomerates, semi-factories and construction facilities that are completely dependent on the skills and technology of the foreign bourgeoisie.

This section will look more closely at the financial activities of the GCC transnational elites, which manifest a new phase of economic connections between the GCC elites and the TCC. To a certain extent, financialization in the GCC indicates more crucial and stable ties between the GCC elites and TCC. While the important merchant families in the region control the GCC conglomerates, it is the royal families themselves who directly engage in important businesses with Western financial firms using the financial power of SWFs controlled by these royal families. 


\section{The Historical Background of GCC Financialization}

This study focuses on the financial ties of the West-GCC relationship. New partnerships independent from oil and gas have been developing over the past decades that render the significance of changes in the global energy market relatively less important. The growing significance of the GCC petrodollars in the "financialization of production" has been central to this process. The term "financialization of production" is in part, the manifestation of increasing reliance by TCC firms on global financial assets to buttress profit margins. The U.S. foreign policy in the GCC is colored by the economic interests of the U.S. capitalist class. In turn, the common interest of the GCC elites and the TCC in terms of capital accumulation have led to the structural penetration of financial globalization into GCC's political economy. This structural shift has been formed by the dominant social strata within global capitalism and in the Arabian Peninsula, i.e., the GCC transnational elites.

Accordingly, analyzing the characteristics of the GCC elites in terms of financial globalization is crucial to better understand the status of these transnational elites within the TCC. Any discussion of the GCC elites without paying attention to the rise of global finance would be an oversimplification. Thus, it is important to analyze the financial characteristics of the GCC states themselves in their interactions with Western countries, the global private sector, and certain global institutions. Using this framework, one can trace the position of the GCC transnational elites within the global financial system. This section will also examine the GCC states' domestic financial system and, in particular, the extent to which the GCC's financial systems depend on the GCC oil sectors. 


\section{The Essence of the GCC's Financial Power}

Structurally speaking, two impacts of oil should be taken into account: the need of industrial powers to have reliable access to oil and gas and the simple fact that extraction, processing and export of oil and oil derivatives bring a large amount of capital surplus. In the previous section, I discussed in detail the need for industrial powers to retain access to oil and gas. This section addresses the characteristics and power dynamic of the capital surplus, which gives considerable power to the agents who control oil. In the case of the GCC states, those agents are the royal families. (See Chart 2.)

The GCC transnational elites have invested their considerable surpluses in the global financial sectors, and the rise of electronic platforms for financialization of production has greatly helped them in this regard. In addition to access to oil revenues, the structural forces that emerged within the TCC have also directed the GCC elite towards engaging in financial activities.

The earlier pattern of the West-GCC oil relations was mostly about the demand for oil itself, where the dominant paradigm of global production was industrialization. In the current phase of industrialization, petrodollars remain a substantial, if not inseparable, part of the new mode of accumulation, i.e. financialization of production. A notable distinction between the previous mode of accumulation and the new one is the growing significance of financial activities of the TCC that could bypass the interests of states - at least the interest of states in the Realist paradigm that conceptualizes the "state" as an autonomous entity. Using financial activities, the GCC has been considerably more successful in advancing and protecting its own business goals. Furthermore, technological 
changes have allowed a "digital techno-economic paradigm" rooted in Information and Communications Technologies (ICTs).

For the new mode of accumulation, oil is not merely a fuel that is necessary for manufacturing, transportation, or providing the basic needs of human societies. The oil revenues in the form of petrodollars are also used at the heart of the global private financial sector. The previous chapters briefly discuss some financial transactions of oil revenues by the GCC, notably SWFs. This chapter explores how petrodollars feed the global financial sector and private financial firms. Before further analysis, however, it is necessary to consider a series of historical facts that have led to the current financial position of the GCC in global capitalism.

The collapse of Bretton Woods strengthened the ability of TCC actors to expand their capital investments and financial ties on a global scale, with the support of states and at the expense of the working class. In post-Bretton Woods era we are witnessing a process of state and TCC-led global financialization that was a response to a crisis of the previous capital accumulation regime (a persistent falling rate of profit). In the GCC, the state had never functioned in a classical sense and states have been always dominated by the ruling classes of the region. But the efforts of the TCC, working with powerful Western states led by the United States, has been deregulating the global finance that contributed to broader global alliances between the TCC and the GCC elites/states. State functions did not diminish; they were redirected for the benefit of transnational capitalist actors who felt that the previous Bretton Woods arrangements were too restrictive and undermined profits. Most TCC interests previously supported the Bretton Woods system until the contradictions of that system proved difficult to sustain profits. Then they aggressively 
lobbied states to reduce costs by policies that weakened labor, reduced regulation, and employed tax breaks, tax havens and the use of global institutions like the IMF and the World Bank, as well as U.S. state power to expand opportunities for foreign investment and financialization at lower costs. The eradication of autonomous functions of states in the West led to the emergence of "neo-liberal states" that are supporting the embedded relationship between the GCC transnational elites and other capitalist states/classes.

At the same time, the process of neo-liberal financialization has been accelerated by the formation of a new techno-economic paradigm that is based on digital technologies. New technologies have helped reduce the pressure of labor markets on the TNCs by making the large part of global labor market more competitive than ever. With the lack of state intervention or an empowered working class, an attractive environment became available to the TNCs, inviting them to shift their resources to the financial sector. At the same time, the private financial sector had the great advantage (compared to private industrial sector) that states could conveniently support them without inviting the objection of powerful labor unions. In the United States, one indication of this state support may be found during and after the recent financial crisis, where the government embarked on the so-called 'national bailout' of certain financial institutions. According to David Harvey, “The term 'national bailout' is. . inaccurate, because they're not bailing out the whole of the existing financial system - they're bailing out the banks, the capitalist class, forgiving them their debts, their transgressions, and only theirs. The money goes to the banks but not to the homeowners who've been foreclosed on, which is beginning to create anger. And the banks are using the money not to 
lend to anybody but to buy other banks. They are consolidating their class power.

(Harvey, March/13/2009, counterpunch)

The distinction between national and global financial circuits is becoming more blurred and diffuse. Therefore, state policies have transnational implications, including the U.S. "bailout" of financial firms, which included transnational firms and actors from a wide range of nationalities, such as investors within the GCC. Thus, the GCC was becoming a much more integrated part of transnational capitalist activities, represented by the investment of petrodollars in the most globally competitive transnational banks. Following the 2008 financial crisis, GCC SWFs were utilized by Western banks as a conduit for investment. It is especially important to note that GCC capital in primarily U.S. banks and in the Eurodollar market was an important countervailing source of revenue for U.S. banks during the 1980s debt crisis in Latin America. In other words, the GCC SWFs have become significant sources of support for the TCC to alleviate the pressure of financial crises on global capital accumulation.

In the GCC a similar structure emerged although with certain differences. In this regard, the main distinction between the GCC states and Western capitalist states is the fact that there is no clear line between the state - i.e. the royal families - and the relevant nonstate actors - wealthy merchants. As discussed before, the family-oriented states of the GCC has legitimized an institutional setting in which influential actors can be both merchant and politicians at the same time. In contrast, in the United States, business actors and political actors are often connected through complex institutional channels, such as lobbies, power clubs and fundraising platforms. In the GCC states the connection between economic and political actors is often arranged around important families through ties of 
kinships and cross-marriages. These patterns create an easy path for development of 'transnational practices' and for further capital accumulation with no significant pressure from the society.

Similar to domestic dependency on oil revenues, the international economic activities of the GCC have pretty much been operating with the financial backbone of energy resources. According to the following chart, in the past few years, the GCC's oil supply has been more than 20 percent of the world's total supply. At the same time, an overwhelming percentage of the GCC states' general revenue depends on absolute and semi-oil revenues (82 percent of UAE's, 90 percent of Bahrain's, 93 percent of Saudi Arabia's, 87 percent of Oman's, 70 percent of Qatar's, and 94 percent of Kuwait's). ${ }^{16}$ Furthermore, the amount of the GCC's petro-dollars has increased "to levels greater than the absorptive capacity of producer national economies can accommodate" (Ehrlich, 1980, P. 97).

\begin{tabular}{|c|c|c|c|c|c|}
\hline & $\mathbf{2 0 0 9}$ & $\mathbf{2 0 1 0}$ & $\mathbf{2 0 1 1}$ & $\mathbf{2 0 1 2}$ & $\mathbf{2 0 1 3}$ \\
\hline Bahrain & 48.68543 & 47.15771 & 48.15771 & 55.15771 & 61.15771 \\
\hline Kuwait & 2505.94295 & 2460.29305 & 2691.81774 & 2796.78775 & 2811.8424 \\
\hline Oman & 818.8882 & 869.85419 & 890.88709 & 923.77348 & 945.12751 \\
\hline Qatar & 1573.24799 & 1787.89912 & 1936.39501 & 2032.6106 & 2067.29912 \\
\hline Saudi Arabia & 9819.17231 & 10642.32729 & 11264.25879 & 11725.67709 & 11591.86153 \\
\hline United Arab Emirates & 2794.55158 & 2813.24377 & 3088.2562 & 3213.19427 & 3229.58771 \\
\hline GCC & 17560.4885 & 18620.77513 & 19919.77254 & 20747.2009 & 20706.87598 \\
\hline World & 84949.3007 & 87524.90902 & 87834.25289 & 89700.26302 & 90057.23626 \\
\hline GCC Share of Total Oil Supply & $36 \%$ & $21 \%$ & $22 \%$ & $23 \%$ & $22 \%$ \\
\hline
\end{tabular}

Table 11: GCC Total Oil Supply (Thousand Barrels Per Day) Source: U.S. Energy Information Administration

\footnotetext{
${ }^{16} \mathrm{https}$ ://www.gulfpolicies.com/index.php?option=com_content $\&$ view=article\&id=1475\&Itemid $=455$, in Arabic
} 
The large oil supply-see table 11- and the inability of the GCC's economic structures to absorb these revenues have brought revenue surpluses to this sub-region. Therefore, it is important to analyze the structural responses of GCC transnational elites to these surpluses. According to one of Deutsche Bank's reports on internal GCC financial markets, "[i]n a global comparison, finance in the GCC has remained small" (Deutsche Bank, 2012, P. 9). GCC-based financial markets are not important when compared to global centers of financial activities such as London or New York. The transnational financial activities of the GCC elites in other regions are considerably higher than their intra-GCC activities. In particular, the GCC elites have used their financial power to help maintain the hegemonic position of the U.S. dollar in the global economy. According to a report produced by Deutsche Bank:

"In the GCC economies, the overall volume of assets managed by institutional investors is large and compares with global institutional assets. Their total value stands at an estimated USD $3.6 \mathrm{tr}$, which corresponds to around 370\% of GDP in the region, i.e. significantly above the global average of institutional assets to GDP of around $230 \%$. GCC institutional assets amount to $2.5 \%$ of the institutional assets under management globally, two-and-a-half times the region's share in global GDP. The distribution of this very high volume of institutional assets in the GCC follows a pattern that underlines the continued strong presence of the state and wealthy families in the region: More than two-thirds of all institutional assets are held by state-sponsored vehicles. . .69\% of the institutional assets in the region are administered by state-sponsored investors, including $45 \%$ held by sovereign wealth funds, $19 \%$ in official reserves, and $5 \%$ by other 
government-sponsored enterprises.” (Deutsche Bank, 2012, P. 20, [“footnotes omitted"])

One main distinction between financial systems in the West and those in the GCC is the fact that the GCC financial system is heavily dependent on oil revenues, and as such is not a separate, independent sector of the economy. Similar to other sectors of the GCC economies, the GCC states do not seem to show infrastructural diversification even after decades of so-called development. All the sections of the economy are still dependent on oil. Therefore, what is shifting in the GCC is not merely financialization, but along with the GCC investments in the industrial private sector, we observe the use of oil revenue in the global financial sector by GCC transnational elites. It is worth noting that both kinds of investments - financial and non- financial - are materialized through the economic ties between the GCC bourgeoisie and the TCC.

\section{Small Financial Sector, But Important}

The GCC does not have an independent financial sector, unlike its energy sector. In other words, the GCC financial sector heavily relies on the oil sector. The other issue is the size of the GCC-based financial systems in contrast to the size of global financial sector. The GCC financial section is generally speaking small. But, when it comes to the role of SWFs in TCC financial institutions, GCC finance plays a crucial role. The SWFs have seen a significant growth trend of investments in TCC financial institutions. To better understand the weakness of GCC-based financial sector, Table 12 shows the percentage of domestic credit provided by the financial sector in GCC, which is considerably lower than the total amount in the world. 


\begin{tabular}{|c|c|}
\hline Countrv Name & $\underline{\mathbf{2 0 1 3}}$ \\
\hline Saudi Arabia & -7.876053 \\
\hline United Arab Emirates & NA \\
\hline Oman & 36.155621 \\
\hline Kuwait & 52.841319 \\
\hline Qatar & 73.854542 \\
\hline Bahrain & 78.35019 \\
\hline GCC Average & 48.240334 \\
\hline European Union & 145.1 \\
\hline OECD members & 202.7 \\
\hline East Asia \& Pacific & 149.8 \\
\hline World & 166.2 \\
\hline
\end{tabular}

Table 12: Domestic credit provided by financial sectors (\% of GDP) ${ }^{17}$ Source: World Bank http://data.worldbank.org/topic/financial-sector

Thus, the GCC financial sector is not powerful in comparison with the Western financial sector. However, this does not mean that the GCC is not an important player within financial globalization. In fact, the GCC-based SWFs that are controlled by individual GCC elites-royal families have been playing an important role in supporting

\footnotetext{
${ }^{17}$ Domestic credit provided by the financial sector includes all credit to various sectors on a gross basis, with the exception of credit to the central government, which is net. The financial sector includes monetary authorities and deposit money banks, as well as other financial corporations where data are available (including corporations that do not accept transferable deposits but do incur such liabilities as time and savings deposits). Examples of other financial corporations are finance and leasing companies, money lenders, insurance corporations, pension funds, and foreign exchange companies. http://data.worldbank.org/indicator/FS.AST.DOMS.GD.ZS
} 
Western financial institutions during difficult times such as during and after the 2008 financial crisis. The support of non-GCC financial institutions by the GCC financial powers was not limited to Western firms. Instead, it seems that during this last global financial crisis, the GCC intended to become a significant financial player on the global scale.

But despite its global motivations the GCC has not been able to improve its financial sector. This failure has been one of reasons why the GCC has not suffered from the implications of financial crisis. On the one hand, the GCC's petrodollar surplus has compensated for the deficit in economic sectors that had been influenced directly by the crisis. On the other hand, there is no properly designed financial sector that could influence the whole economy of the GCC countries. Instead of propping up domestic economies, the GCC's petrodollars were transferred to important global financial corporations. The following table shows important transactions involving the GCC during the financial crisis. 


\begin{tabular}{|c|c|c|c|}
\hline Date & $\begin{array}{l}\text { Target } \\
\text { Company }\end{array}$ & Sovereign Wealth Fund(s) & $\begin{array}{l}\text { Investment size in US \$ } \\
\text { (Percent stake in target) }\end{array}$ \\
\hline $10 / 31 / 2008$ & Barclays & $\begin{array}{c}\text { Abu Dhabi Royal Family; Qatar } \\
\text { Holding; Challenger Universal } \\
\text { (Qatar) }\end{array}$ & US \$11.8 billion (31.5\%) \\
\hline $10 / 16 / 2008$ & Credit Suisse & $\begin{array}{c}\text { Qatar Investment Authority } \\
\text { (QIA) }\end{array}$ & US $\$ 2.2$ billion \\
\hline $1 / 15 / 2008$ & Citigroup & $\begin{array}{c}\text { GIC(Singapore), KIA (Kuwait), } \\
\text { Prince Alwaleed bin Talal (Saudi } \\
\text { Arabia) }\end{array}$ & US $\$ 12.5$ billion (9.3\%) \\
\hline $1 / 15 / 2008$ & Merrill Lynch & $\begin{array}{l}\text { Korea Investment Corporation } \\
\text { (S.Korea), KIA (Kuwait), Mizuho } \\
\text { Corporate Bank (Japan), et al. }\end{array}$ & US \$6.6 billion (14.5\%) \\
\hline $11 / 27 / 2007$ & Citigroup & $\begin{array}{l}\text { Abu Dhabi Investment } \\
\text { Authority (ADIA) }\end{array}$ & US $\$ 7.5$ billion ( $4.9 \%$ stake) \\
\hline 11/7/2007 & Apollo & $\begin{array}{l}\text { Abu Dhabi Investment } \\
\text { Authority (ADIA) }\end{array}$ & $9 \%$ (amount not disclosed) \\
\hline $10 / 30 / 2007$ & Och-Ziff & $\begin{array}{c}\text { Dubai International Capital } \\
\text { (DIC) }\end{array}$ & US \$1.26 billion (9.9\%) \\
\hline $9 / 20 / 2007$ & Carlyle Group & Mubadala (Abu Dhabi) & US $\$ 1.25$ billion $(7.5 \%)$ \\
\hline
\end{tabular}

Table 13: GCC-SWF Capital Infusions into Financial Institutions

Source: Barrowed from Table 2, Review of SWF Capital Infusions Into Financial Institutions

(May 2006- June 2009),

(Sauvant et. al., 2012, P. 45)

Arguably, more important than the amounts of money transferred from the GCC to these financial corporations is the crucial role that has been played by the GCC elites in saving the process of financial globalization by exerting substantial political and economic power. This is parallel with what happened within the Western capitalist systems through the same financial institutions that the GCC had investments in. According to Joseph 
Stiglitz, the "political action committees and employees of securities and investment gave $\$ 156$ million in political contributions in the 2008 election cycle. Goldman Sachs, Citigroup, JP Morgan Chase, Bank of America, and Credit Suisse gave \$22.7 million and spent more than $\$ 25$ million combined on lobbying in the period" (Stiglitz, 2010, P. 343; note that in 2009 Merrill Lynch was officially acquired by Bank of America). During the same election period, Barclays, Apollo Global Management and Carlyle Group spent more than $\$ 4.5$ million on lobbying. ${ }^{18}$ While the content of these lobbying activities may not be all clear, one obvious outcome has been the overall support of the U.S. government for the U.S. financial sector, instead of placing further restrictions and regulations on financial activities that brought about the crisis in the first place. The state provided generous loans to the private sector under the rationale that institutions such as AIG were "too big to fail." As for the GCC's involvement, it may be added that they started investing in Western corporations when these corporations were on the edge of collapse - that is, at a time when no other business actor seemed interested to invest in financial firms. These investments may be explained by an interest in protecting class power and in further re- consolidation of the TCC and capital accumulation.

The above-mentioned financial activities show the depth of the financial ties between the GCC transnational elites and TCC. The real significance of the GCC financial sector is its role in protecting and promoting the interests and position of the GCC transnational elites - a position that can be elevated by protecting the financial interests of the TCC.

\footnotetext{
${ }^{18}$ data are available at http://www.opensecrets.org/
} 


\section{The GCC's Role in Global Financial Institutions}

David Harvey describes the 2008 financial crisis "as a class event in which a certain structure of exploitation broke down and is about to be displaced by an even deeper structure of exploitation" (Harvey, March/13/2009, counterpunch). The previous discussion regarding the GCC's financial involvements in the 2008 crisis suggests that Harvey's description may have some merit. As Harvey had predicted the outcome of the crisis, neo-liberalism has successfully survived the crisis if we consider it as a "class project." Eventually, the financial firms could convince the necessary decision-makers about the validity of the discourse of "too-big-to fail." The two aspects of Harvey's explanation - the "class project" nature of neo-liberalism and the deeper structure of exploitation - are arguably manifested in the transaction between the GCC transnational elites and their TCC counterparts. The role of Saudi Arabia, in particular, has been considerable within the global financial system in a way in which Saudis' assistance to capitalist institutions has become crucial.

The GCC also has a significant role within global financial institutions. Saudi Arabia is among the eight executive members of the IMF along with the United States, Japan, Germany, France, United Kingdom, China and Russian Federation. Compared to the other executive members, Saudi Arabia's small financial sector is almost completely framed by external advisory groups such as the World Bank's Technical Cooperation Program (TCP) and International Finance Corporation (IFC). According to an IMF report, "IFC is working closely with Saudi public institutions and International Financial Institutions (IFIs) to undertake global initiatives that benefit private sector activities in developing countries. So far, these efforts have resulted in obtaining commitments of over 
US\$500 million" (Staff Report For The 2-14 Article IV Consultation-Informational Annex, P. 4). With the leading role of Saudi Arabia, the GCC participates in some significant global arrangements, mostly through the IMF and the World Bank.

In terms of the IMF, Saudi Arabia agreed to assist in implanting certain financial strategies such as the General Arrangements to Borrow (GAB) and the New Arrangements to Borrow (NAB). Under GAB:

“. . member countries are enabled to borrow specified amounts of currencies from eleven industrial countries (or their central banks), under certain circumstances, at market related rates of interest. As at the beginning of 2002, the potential amount of credit available to the Fund under the GAB totaled SDR 17 billion (around US $\$ 22$ billion), with an additional SDR 1.5 billion available under an associated arrangement with Saudi Arabia". (Shekhar, 2009, P. 479)

As seen in to Chart 3, Saudi Arabia is the eighth contributor to the IMF among 38 IMF members. GAB was initiated in 1962; however, its framework has been changing since its inception. GAB is one of the IMF tools for stabilizing the global financial system. It was used particularly after the recent financial crisis. GAB has been criticized as a vehicle for re-consolidating the power of the Group of Ten over the Global South. NAB, on the other hand, has been established in order to increase the power of GAB, and further protect the hegemonic position of the G-10 within the financial system.

According to another IMF report, "[i]n June 1995, the Group of Seven summit meeting in Halifax, Canada called on the Group of Ten (G-10) and other countries with the financial capacity to support the international monetary system to develop financing arrangements with the aim of doubling as soon as possible the amount of currency available 
under the GAB." ${ }^{19}$ Because China is the third largest contributor to the IMF, it was believed at the time that China could "easily arrange coalitions that could block the borrowing facility if that was in its interests," thereby derailing the IMF efforts to rehabilitate the global financial system (Heep, 2014, P. 125). Saudi Arabia is not among the G10 states, but it is one of the G20. Saudi Arabia mad a sizable contribution to doubling the size of GAB (through the creation of NAB) - a contribution more than the combined contribution of four members of the G10, including the Netherlands, Belgium, Sweden, and Switzerland (see the following chart). This sizable Saudi contribution alleviated some concerns about China's potential undermining of the IMF's efforts. Despite Saudi's generosity, the country has never been rewarded with decision-making powers in global financial institutions such as the IMF.

${ }^{19}$ https://www.imf.org/external/np/sec/pr/1997/PR9705.HTM 


\section{Amount}

(SDR million)

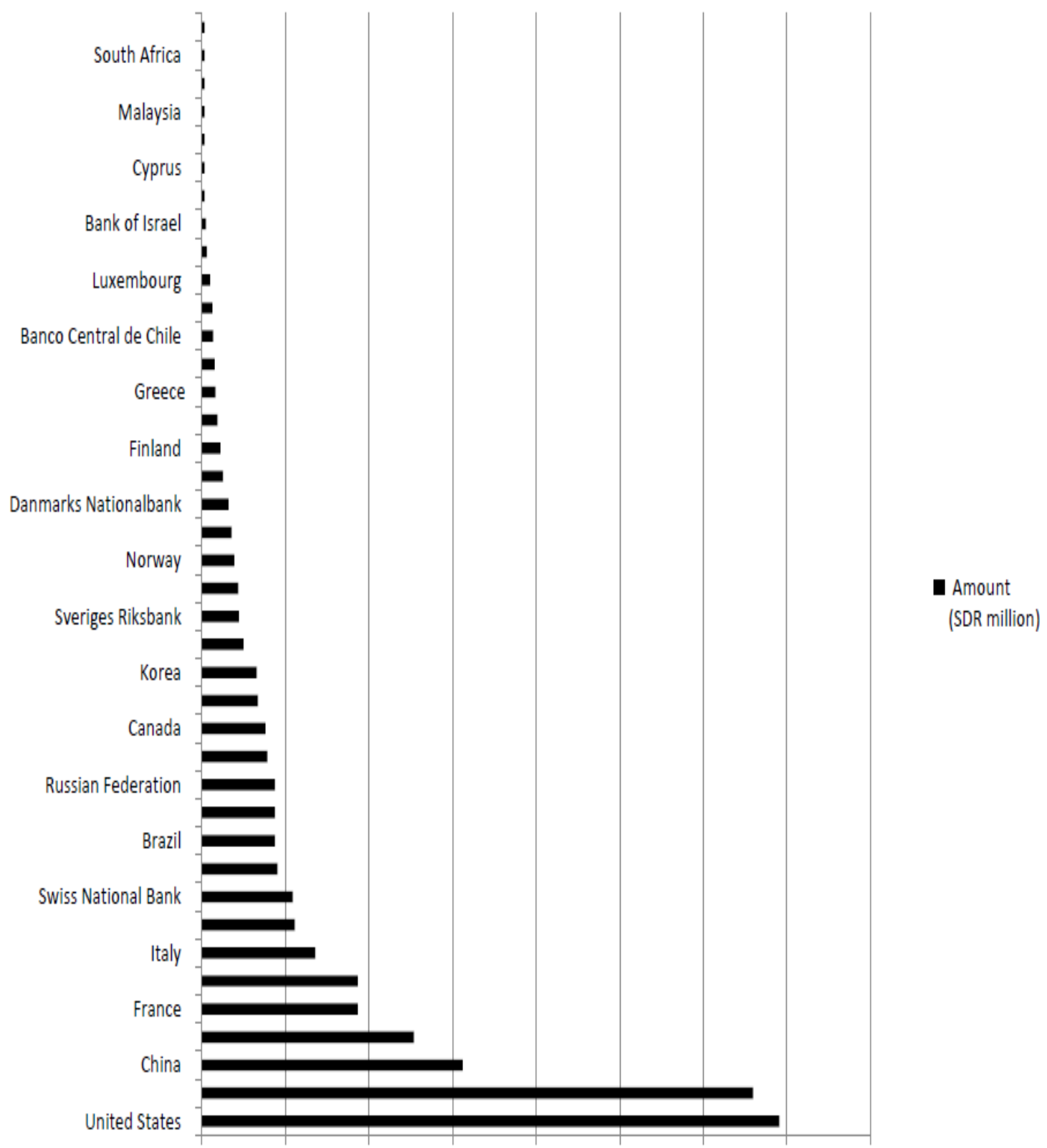

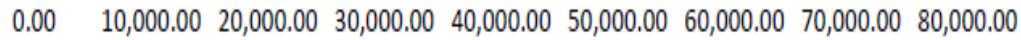

Chart 3: Amount of Contributions in NAB by Country

Source: https://www.imf.org/external/np/exr/facts/pdf/gabnab.pdf, based on the data on page1, NAB Participants and Credit Amounts, 201 
The Neo-Gramscian understanding of the hegemonic power explains why, despite Saudi Arabia's exclusion from the decision-making process, it has made sizeable contributions to the IMF. According to Neo-Gramscian theories a mutual acceptance of the hierarchy of power between the global south and the global north is pivotal in the establishment and endurance of the hegemonic power. The mutual acceptance of the hierarchy functions as a shock absorber for the inherent uncertainty within capitalism. Moreover, one can compare the IMF financial agreements with the Marshall Plan that pursued two strategic goals at the same time: political intervention and promotion of a capitalist system. In Soederberg's words, "it becomes clear that the NAB was an attempt to reproduce the political domination of the IMF in the South. . . the NAB, like its counterpart the $\mathrm{GAB}$, is based on a putative interstate consensus. Hence the lack of legal mandate attached to the NAB and the choice of wording 'Arrangement' not 'Agreement' seemed to replicate the imposed U.S. leadership" (Soederberg, 2004, pp. 101-102).

It is worth considering once again the outcome of the current financial relationship between Saudi Arabia (and the GCC) with the IMF. As I argued earlier, the relationship between the two sides remains, at its core, a class project. The financial arrangement is intended to guarantee the stability of the GCC authoritarian status quo in return for their role in stabilizing the global financial sector for the TCC (both through private channels and via international institutions). The NAB, in particular, has been designed to ensure financial stability. According to the IMF, "potential participants [in NAB] have agreed to meet once a year at the time of the Annual Meetings of the IMF to discuss, among other matters pertaining to the $\mathrm{NAB}$, macroeconomic and financial markets developments, especially those that could have an impact on the stability of the financial system and lead 
to a possible need for the IMF to seek supplementary resources." ${ }^{20}$ NAB is particularly important given the powerful destabilizing forces unleashed by the new capitalist mode of accumulation that relies on financial globalization. We observe a new role of the GCC in stabilizing TCC banks through infusions of capital which link them in mutual profitmaking enterprises with the TCC.

It is not surprising that the outcome of the interaction between the GCC and the West appears to undermine the mainstream claim that "there is a positive and statistically significant correlation between democracy, open capital flows and redistributive domestic social policies" (Dailami, 2000, P. 25). As demonstrated in Figure 6, the GCC region has experienced relatively high financial openness during the past decade. Financial openness is a particularly important analytical index because of the deepening financialization of the global economy that has served to tie a wide range of capitalist interests together in linked profit-making ventures. Financial openness is a more accurate measure than trade openness for examining economic openness of a country in the current phase of globalization. Similar to the argument made in the first chapter on the relationship -or lack thereof between overall economic openness and democracy in the GCC, the high level of financial openness in the GCC supports the stability of authoritarian regimes. Figure 7 indicates the recent status of the GCC states in terms of democracy relative to the global average. It also provides scores for financial openness.

\footnotetext{
${ }^{20}$ https://www.imf.org/external/np/sec/pr/1997/PR9705.HTM
} 


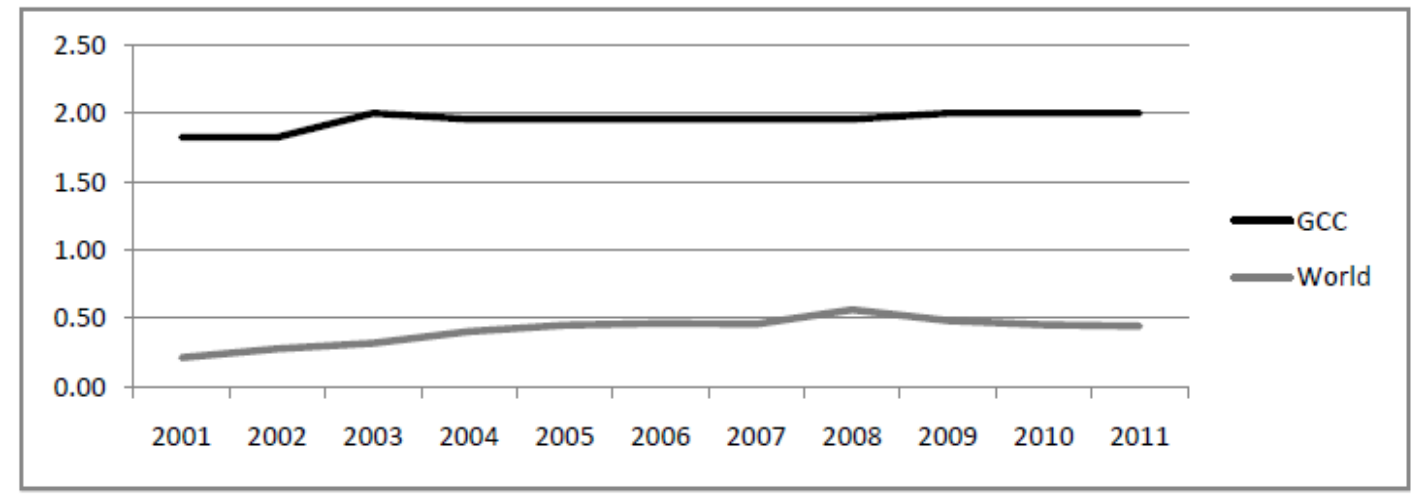

Figure 6: The Chinn-Ito Index for Financial Openness for GCC and World ${ }^{21}$ Source: http://knoema.com/bzftmbe/the-chinn-ito-financial-opennes-index

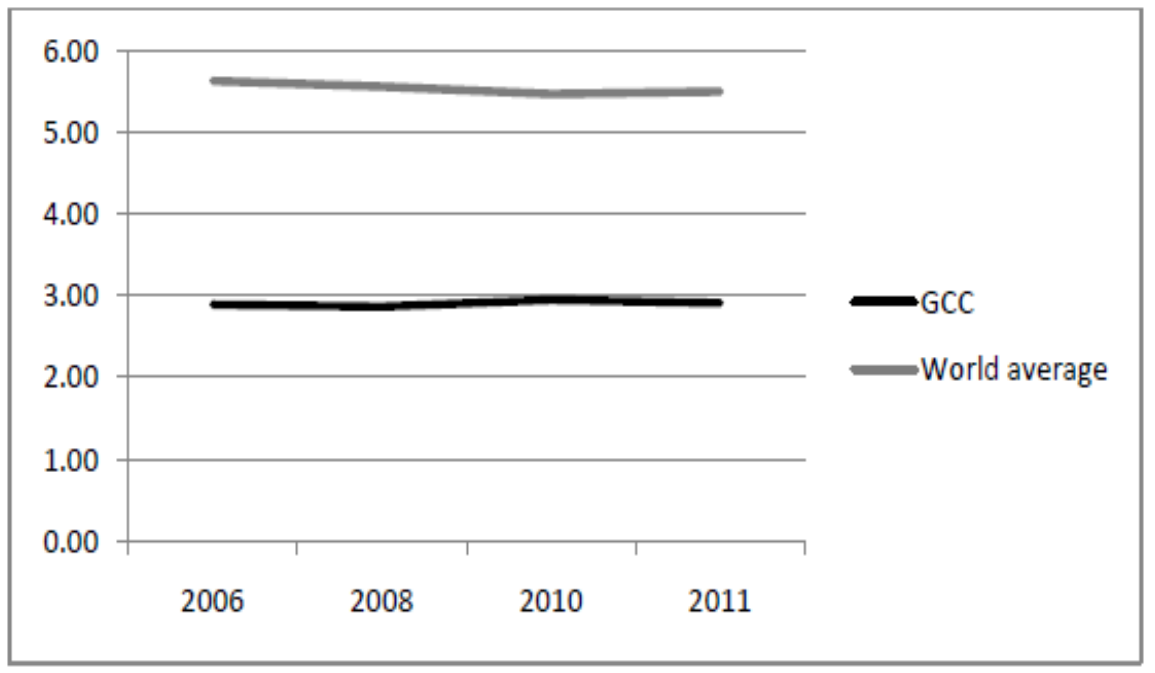

Figure 7: Democracy Index 22

Source: http://www.sudestada.com.uy/Content/Articles/421a313a-d58f-462e-9b242504a37f6b56/Democracy-index-2014.pdf

21 "The Chinn-Ito index (KAOPEN) is an index measuring a country's degree of capital account openness. The index wasinitially introduced by Chinn and Ito (Journal of Development Economics, 2006). KAOPEN is based on the binary dummy variables that codify the tabulation of restrictions on cross-border financial transactions reported in the IMF's Annual Report on Exchange Arrangements and Exchange Restrictions (AREAER)". Available here: http://knoema.com/bzftmbe/the-chinn-ito-financial-opennes-index

${ }^{22} \mathrm{http}: / / \mathrm{www}$. sudestada.com.uy/Content/Articles/421a313a-d58f-462e-9b242504a37f6b56/Democracy-index-2014.pdf 
Given the above scores and the documented ties of financial connections between the GCC and the TCC, it is reasonable to conclude that the financial openness in the GCC is essentially a class project to stabilize the status quo of the GCC transnational elites. In turn, the GCC transnational elites, primarily the Saudis, have been supporting both international financial institutions and the global financial private sector during financial crises.

\section{Conclusion}

This chapter discussed two significant components of the GCC capitalist class. The first component is the GCC conglomerates that are controlled by a network consisting of the GCC royal families and important merchant families. The second component is the SWF-based financial activities that are mainly controlled by the GCC royal families. Therefore, the two capitalist agents in the region - the GCC royal families and the GCC merchant families - control the two key capitalist institutions in the region, SWFs and the GCC conglomerates, which are the primary shapers and promoters of the GCC transnational space. They have strong connections with significant multinational corporations and with the TCC. They control all state institutions that are used for the purpose of transnational capital accumulation. The GCC states play a significant role in the process of transnationalization. SWFs that are supposedly "state-owned" institutions are the nexus of transnational capital accumulation in the age of modern financial activities. They are private enough to provide a comfortable setting for the global capitalist class to protect its interests, and they are public enough to avoid the usual regulatory scrutiny targeting private institutions. As William Robinson puts it: 
“. . the TNS is a transnational capitalist state because its own reproduction is dependent on reproducing the circuits of transnational accumulation. This is so for a majority of the organs that make up the TNS network, in particular, national states networked into larger international forums, such as UN agencies, the G-20, the IMF, and the WB. (Robinson, 2014, P. 75)

The other significant role that the GCC states play in terms of transnational capital accumulation is that their repressive political machines provide stability for its transnational actors and, above all, for the royal families. Therefore, states are in essence capitalist entities for the GCC bourgeoisie that maintain the current transnational space while giving a disproportionate power for capital accumulation to the capitalist class. As a vehicle to enforce the conditions for accumulation, states repress the working class by militarized means, which is a classic part of the structure of global capitalism. In the next chapter I will focus on the repressive characteristics of the states' machinery within the GCC.

With respect to the financial activities of GCC transnational elites, the mode of financialization in GCC is coordinated with international corporations that are globally significant. This phase of transnational capital accumulation dramatically sped up during the 2008 financial crisis. During that period, the GCC transnational elites started investing in failing Western financial institutions that were controlled by members of the TCC who were already well-connected to the GCC transnational elites. The role played by the GCC transnational elites to help out their TCC counterparts during the crisis elevated the power of the former vis-à-vis the latter group. 
Today, GCC's economy is not merely controlled by family businesses, but also by conglomerates that are arguably the main economic actors in the region and connect the region to other regions and global cities. These conglomerates have many joint ventures with powerful foreign states and corporations. The GCC conglomerates are obviously dominated by the interests of the GCC royal families. The merchant families have economic and familial ties with the royal families, who play an aristocratic role in promoting and protecting the interests of the patron royal families. Arguably, this subclass of merchant families is an extension of the core capitalist class in the GCC -- the royal families. 
APPENDIX II: The Business Activities of GCC Conglomerates 


\section{Kingdom Holding (Prince Alwaleed Bin Talal)}

In 1991, the Prince invested \$590 million in Citicorp, which merged with Travelers Group in April 1998 forming the world's largest financial institution, Citigroup, with over $\$ 1$ trillion of assets and around $\$ 100$ billion of equity. In 1993, invested \$100 million in Saks Incorporated which operates Saks Fifth Avenue department stores, New York's upscale fashion retailer, buying approximately a $10 \%$ stake.

In 1994, acquired a 50\% stake in Fairmont hotel chain. A share swap in 2003 has lead to a $4.9 \%$ stake in the parent company of Fairmont Hotels \& Resorts.

In 1994, invested around $\$ 345$ million acquiring $24 \%$ of Disneyland Paris, located outside the French capital. Current stake stands at $17.3 \%$ of the company.

In 1994, invested $\$ 120$ million to acquire $22 \%$ of the Four Seasons Hotels Inc., a Canadian luxury hotel chain. In 2007 , the Board of Directors of Four Seasons jointly agreed to the US\$ 3.8 billion acquisition deal by Prince

In 1995, acquired a 42\% stake in the landmark New York Plaza Hotel for \$300 million. In 2001, the stake increased to $50 \%$. 1995: Jointly control with a group of international investors of Canary Wharf, the largest European real In 1996, the purchase of the George $V$ hotel in Paris for $\$ 185$ million and renovating it for $\$ 120$ million. After restoring its elegance and prestige, the hotel reopened in December 1999.

In 1997, premier investment in the technology industry acquiring a 5\% stake in Apple Computers Inc. for \$115 In 1997, invested \$10 million in Palestine Development \& Investment Ltd. Company (PADICO), engaged in construction and development projects in the West Bank and Gaza Strip.

In 1997, acquisition of a $27 \%$ stake in Mövenpick Hotels \& Resorts. In addition to Europe, the Swiss hotel chain is managing and developing hotels in Saudi Arabia, Lebanon, Jordan, Egypt, Qatar, Morocco, Tunisia, and Libya. In In 1997, invested $\$ 400$ million acquiring $5 \%$ of the preferred shares of News Corp., which encompasses Harper Collins, The Sunday Times-UK, Fox News, Sky, Star TV and many more. In 1999, the investment was raised to $\$ 600$ In 1997, invested \$146 million for 5\% of Netscape, later acquired by America Online (AOL) which merged with TIME/Warner creating the world's largest media company, AOL Time Warner. Investment was raised to more In 1997, invested \$300 million in Motorola which specializes in wireless communications, semiconductors and electronic systems, components, and services.

In 1998, the purchase of 100,000 acres in Tushka, Egypt, for agricultural development through Kingdom Agricultural Development Company (KADCO). Upon completion, total investment will reach $\$ 500$ million. In 2000, invested \$400 million in Compaq Computer Corp., the world's second largest computer company. In 2002 Compaq merged with HP creating the world's leading consumer technology company.

In 2000, invested \$100 million in Kodak, maker of photographic films and papers for a wide range of consumer, entertainment, professional, business, and health-related uses.

In 2000, invested \$50 million in eBay Inc., a person-to-person trading community on the Internet. Sellers use the company's service to exchange personal items.

In 2000, invested \$50 million. The stake was raised to \$100 million. In September 2001, the shareholding was In 2000, invested $\$ 50$ million in Procter \& Gamble (P\&G), a world-wide manufacturer of wide ranging products. In 2000, invested \$50 million in PepsiCo, Inc.

In 2000, invested \$50 million in Walt Disney, operator of media networks, studio entertainment, theme parks and resorts, consumer products, Internet and direct marketing ventures.

In 2003, acquired nearly 5\% of International Financial Advisors Company (IFA), a leading Kuwaiti investment

In 2004, acquired nearly 5\% of Kuwait Invest Holding Company.

In 2004, HRH Prince Alwaleed signs agreement with Dr. Mustafa Ghandoor allowing KHC to acquire a 40\% stake in

In 2004, Kingdom Zephyr is the manager of parallel Pan-African private equity funds, Pan African investment

Partners Limited (“PIAP, a Mauritius company) and Pan-Commonwealth African Partners Limited (“PAIP/PCAP”), In 2005, the venture between Kingdom Hotels International, Fairmont Hotels \& Resorts Inc., and Bank of Scotland Corporate, has completed the purchase of the Monte Carlo Grand hotel in Monaco and the property is to be In 2005, acquisition of a 96\% interest in the 251-room Royal Palm Hotel in Dar Es Salaam, Tanzania, one of East Africa's most vibrant economic hubs. The hotel, which first opened in 1995, is located in the business district of In 2005, the Kingdom Hotels International, Fairmont Hotels \& Resorts Inc., and Bank of Scotland Corporate venture, has completed the purchase of the Savoy Hotel in London for $\$ 400$ million. The property is to be flagged In 2006, Kingdom Hotels International and Colony Capital entered a US\$5.5 billion acquisition agreement of Fairmont Hotels \& Resorts combining it with Raffles Hotels \& Resorts of Singapore.

In 2007, acquisition of 29.9\% if the Saudi Research and Marketing Group (SRMG). The publications that fall under SRMG include Asharg Al Awsat, Al Eqtisadiah,Arab News, Hia magazine, Al Majalla magazine, Arrajol magazine and Sayidati magazine. Furthermore, other entities that fall under SRMG are Al khaleejiya for Publicity Advertising and In 2007, Kingdom Holding Company acquired 12\% of the National Air Services Company Limited (“NAS”),a private Saudi airline company for $\$ 100$ million. The ownership percentage increased to $37 \%$ in 2008 .

Source: https://publicintelligence.net/kingdom-holding-company/ 


\section{Dallah Al-Baraka Group Profile}

\section{International Businesses:}

\begin{tabular}{|c|c|}
\hline Subsidiary & Country \\
\hline Banque Albaraka D'algeria & Algeria \\
\hline Al-Tawfeek Co. For Investment Funds Ltd. & $\begin{array}{c}\text { Cayman } \\
\text { Islands }\end{array}$ \\
\hline Banque Albaraka D'jibouti & D'jibouti \\
\hline Misr Arab Poultry Co & Egypt \\
\hline Algerian Saudi Leasing Holding Co. & France \\
\hline Jordan Islamic Bank & Jordan \\
\hline Dallah Albarak Holding Co. & Malaysia \\
\hline Dallah Al-Baraka & Malaysia \\
\hline Holding SDN. BHD. & Malaysia \\
\hline Banque Albaraka Mauritanienne & \\
Islamique & Mauritanian \\
\hline Sardine Canning Co & Morocco \\
\hline Al-Towfeek Investment Bank Ltd. & Pakistan \\
\hline Albaraka Bank Ltd. & South Africa \\
\hline Albaraka Bank & Sudan \\
\hline BEST Re-Insurance & Tunisia \\
\hline Beit Et-Tamweel Al-Tunisi Al-Saudi & Tunisia \\
\hline Dallah Albaraka & U.K. \\
\hline Albaraka Bancorp & USA \\
\hline
\end{tabular}

Source: https://www.albaraka.com/, http://www.dallah.com/ 


\section{GCC Businesses}

\begin{tabular}{|c|c|}
\hline Subsidiary & Country \\
\hline Albaraka Islamic Investment Bank & Bahrain \\
\hline Al-Amin Co. For Securities \& Investment Funds & Bahrain \\
\hline Islamic Insurance \& Re-Insurance Co. (IIRCO) & Bahrain \\
\hline Egyptian-Saudi Finance Bank & Egypt \\
\hline International Arab Leasing and Finance Company & $\begin{array}{l}\text { France, Tunisia, Saudi } \\
\text { Arabia }\end{array}$ \\
\hline Albaraka Bank & Lebonan \\
\hline $\begin{array}{c}\text { International Information \& Trading Services } \\
\text { Company }\end{array}$ & NA \\
\hline Iqraa Co. for Printing and Paper Trading & NA \\
\hline National Wood Works Co & NA \\
\hline Albaraka Medical Clinic & Saudi Arabia \\
\hline Arab Leasing International Finance (ALIF) Ltd & Saudi Arabia \\
\hline Arab Radio \& Television (ART) & Saudi Arabia \\
\hline Arab Reach Media (ARM) & Saudi Arabia \\
\hline $\begin{array}{l}\text { Dallah Albaraka Holding Company for Umra } \\
\text { Services }\end{array}$ & Saudi Arabia \\
\hline Dallah Communications Holding & Saudi Arabia \\
\hline $\begin{array}{l}\text { Dallah Establishment for Contracting and } \\
\text { Maintenance }\end{array}$ & Saudi Arabia \\
\hline Dallah Health Service Holding Company & Saudi Arabia \\
\hline Dallah Hotels and Resorts & Saudi Arabia \\
\hline Dallah Human Skills Development Co & Saudi Arabia \\
\hline Dallah Transport Co. Ltd & Saudi Arabia \\
\hline Dallah-Dowail Co. & Saudi Arabia \\
\hline Saudi Digital Distribution Company & Saudi Arabia \\
\hline Saudi Real Estate Maintenance Co & Saudi Arabia \\
\hline Albaraka Turkish Finance House & Turkey \\
\hline Emin Sigorts A.S. & Turkey \\
\hline Islamic Arab Insurance Co (IAIC) & UAE \\
\hline
\end{tabular}

Source: https://www.albaraka.com/, http://www.dallah.com/ 


\section{SABIC}

\begin{tabular}{|c|c|c|c|}
\hline Company & Location & Partnership & Products \\
\hline Alba Aluminium Bahrain & Bahrain & $\begin{array}{l}\text { SABIC Industrial Investments Company } \\
(20 \%) \text {, State of Bahrain (77\%), Brenton } \\
\text { Investments, Germany (3\%) }\end{array}$ & $\begin{array}{l}\text { Aluminum (liquid metal, ingots, rolling slabs, and } \\
\text { billet) }\end{array}$ \\
\hline Al-Bayroni Al-Jubail Fertilizer Company & Al-Jubail, Saudi Arabia & $\begin{array}{l}\text { A 50/50 SABIC joint-venture with } \\
\text { Taiwan Fertilizer Company }\end{array}$ & Ammonia, urea, 2-ethyl hexanol, and DOP \\
\hline Ar-Razi Saudi Methanol Company & Al-Jubail, Saudi Arabia & $\begin{array}{l}\text { A 50/50 SABIC joint-venture with a } \\
\text { consortium of Japanese companies led } \\
\text { by Mitsubishi Gas Chemical Company }\end{array}$ & Chemical-grade methanol \\
\hline $\begin{array}{l}\text { GARMCO Gulf Aluminum Rolling Mill } \\
\text { Company }\end{array}$ & Bahrain & $\begin{array}{l}\text { SABIC (31.28\%), Kuwait (16.97\%), } \\
\text { Bahrain (38.36\%), Iraq (4.12\%), Oman } \\
\text { (2.06\%), Qatar (2.06\%), and Gulf } \\
\text { Investment Corporation (5.15\%) }\end{array}$ & Aluminum sheets and can stocks \\
\hline Gas National Industrial Gases Company & $\begin{array}{c}\text { Al-Jubail, Saudi Arabia (head } \\
\text { office); Yanbu, Saudi Arabia } \\
\text { (branch) }\end{array}$ & $\begin{array}{c}\text { SABIC }(70 \%) \text { and a group of Saudi } \\
\text { Arabian private-sector companies }(30 \%)\end{array}$ & $\begin{array}{l}\text { Oxygen, nitrogen, argon and krypton/xenon (Al- } \\
\text { Jubail); oxygen and nitrogen (Yanbu) }\end{array}$ \\
\hline $\begin{array}{l}\text { GPIC Gulf Petrochemical Industries } \\
\text { Company }\end{array}$ & Bahrain & $\begin{array}{l}\text { Joint-venture with equal partnership for } \\
\text { the Petrochemical Industries Company } \\
\text { of Kuwait, State of Bahrain and SABIC }\end{array}$ & Methanol, ammonia, and urea \\
\hline Hadeed Saudi Iron and Steel Company & Al-Jubail, Saudi Arabia & A wholly owned affiliate of SABIC & $\begin{array}{l}\text { Steel rebar, wire rod, hot-rolled coils, cold-rolled } \\
\text { coils, galvanized coil, and flat-steel products }\end{array}$ \\
\hline $\begin{array}{l}\text { Ibn Al-Baytar National Chemical Fertilizer } \\
\text { Company }\end{array}$ & Al-Jubail, Saudi Arabia & 50/50 SABIC joint-venture with SAFCO & $\begin{array}{l}\text { Ammonia, urea, compound fertilizer, phosphate, } \\
\text { and liquid fertilizer }\end{array}$ \\
\hline $\begin{array}{l}\text { Ibn Rushd Arabian Industrial Fibers } \\
\text { Company }\end{array}$ & Yanbu, Saudi Arabia & $\begin{array}{c}\text { SABIC }(45.19 \%) \text {, PIF (33.51\%), and a } \\
\text { group of Saudi Arabian and regional } \\
\text { private-sector partners (21.30\%) }\end{array}$ & $\begin{array}{l}\text { Aromatics (xylenes and benzene), purified } \\
\text { terephthalic acid (PTA), bottle-grade chips, PET, } \\
\text { and acetic acid }\end{array}$ \\
\hline Ibn Sina National Methanol Company & Al-Jubail, Saudi Arabia & $\begin{array}{c}\text { SABIC (50\%), CTE (50\% - owned by } \\
\text { Elwood Insurance Ltd., } 25 \% \text {, and Texas } \\
\text { Eastern Arabian Ltd., 25\%) }\end{array}$ & Chemical-grade methanol and MTBE \\
\hline $\begin{array}{l}\text { Ibn Zahr Saudi European Petrochemical } \\
\text { Company }\end{array}$ & Al-Jubail, Saudi Arabia & $\begin{array}{l}\text { SABIC (80\%), Ecofuel-Italy (10\%), Arab } \\
\text { Petroleum Investment Corporation } \\
\text { APICORP (10\%) }\end{array}$ & MTBE and polypropylene \\
\hline Kemya Al-Jubail Petrochemical Company & Al-Jubail, Saudi Arabia & $\begin{array}{c}\text { A 50/50 SABIC joint-venture with } \\
\text { ExxonMobil (USA) }\end{array}$ & Polyethylene and ethylene \\
\hline $\begin{array}{l}\text { Petrokemya Arabian Petrochemical } \\
\text { Company }\end{array}$ & Al-Jubail, Saudi Arabia & A wholly owned affiliate of SABIC & $\begin{array}{c}\text { Ethylene, polystyrene, butene-1, propylene, } \\
\text { butadiene, benzene, polyethylene, VCM, E-PVC, } \\
\text { S-PVC, and ABS }\end{array}$ \\
\hline Sadaf Saudi Petrochemical Company & Al-Jubail, Saudi Arabia & $\begin{array}{l}\text { A 50/50 SABIC joint-venture with Shell } \\
\text { Chemicals Arabia, LLC (an affiliate of } \\
\text { Royal Dutch Shell) }\end{array}$ & $\begin{array}{l}\text { Ethylene, crude industrial ethanol, styrene, } \\
\text { caustic soda, ethylene dichloride, and MTBE }\end{array}$ \\
\hline SAFCO Saudi Arabian Fertilizer Company & Al-Jubail, Saudi Arabia & $\begin{array}{c}\text { SABIC (42.99\%), GOSI and Public } \\
\text { Pension Agency (15.4\%), public } \\
\text { shareholders (41.61\%) }\end{array}$ & Ammonia, urea, and urea formaldehyde \\
\hline SABIC Innovative Plastics & Bay St. Louis, Mississippi, USA & A wholly owned affiliate of SABIC & CYCOLAC ${ }^{T w}$, CYCOLOY \\
\hline SABIC Innovative Plastics & Bergen op Zoom, Netherlands & A wholly owned affiliate of SABIC & 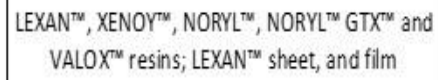 \\
\hline
\end{tabular}




\begin{tabular}{|c|c|c|c|}
\hline Company & Location & Partnership & Products \\
\hline SABIC Innovative Plastics & Burkville, Alabama, USA & A wholly owned affiliate of SABIC & LEXAN $^{\mathrm{TM}}$ resin \\
\hline SABIC Innovative Plastics & Cartagena, Spain & A wholly owned affiliate of SABIC & $\begin{array}{l}\text { LEXAN }^{T M}, \text { EXTEM }^{T M}, \text { ULTEM }^{T M} \text {, and } \\
\text { CYCOLOY } \\
\text { resins }\end{array}$ \\
\hline SABIC Innovative Plastics & Mt. Vernon, Indiana, USA & A wholly owned affiliate of SABIC & 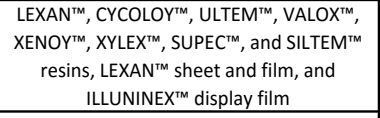 \\
\hline SABIC Innovative Plastics & Ottawa, Illinois, USA & A wholly owned affiliate of SABIC & CYCOLAC $^{\mathrm{TM}}$, CYCOLOY'M , and GELOY'TM resins \\
\hline SABIC Innovative Plastics & Selkirk, New York, USA & A wholly owned affiliate of SABIC & $\begin{array}{c}\mathrm{PPO}^{\mathrm{TM}} \text { resin, } \mathrm{NORYL}^{\circledast}, \mathrm{NORYL} \mathrm{PPX}^{\circledast} \text { and } \\
\text { NORYL GTX }{ }^{\circledast} \text { resins, and high-impact } \\
\text { polystyrene (HIPS) } \\
\end{array}$ \\
\hline SABIC Innovative Plastics & Washington, West Virginia, USA & A wholly owned affiliate of SABIC & CYCOLAC $^{T M}$, CYCOLOY $^{T M}$, and GELOY ${ }^{T M}$ resins \\
\hline SABIC Innovative Plastics & Wixom, Michigan & $\begin{array}{l}\text { Exatec LLC }- \text { A wholly owned affiliate of } \\
\text { SABIC }\end{array}$ & PC automotive glazing \\
\hline SABIC Petrochemicals B.V. & Geleen, Netherlands & A wholly owned affiliate of SABIC & $\begin{array}{c}\text { Polyethylene (HDPE, LDPE, LLDPE), } \\
\text { polypropylene, ethylene, propylene, } \\
\text { butadiene, MTBE/ ETBE, benzene, gasoline } \\
\text { components, styrene, C9 resin feed, cracked } \\
\text { distillate, acetylene, hydrogen, and carbon- } \\
\text { black oil }\end{array}$ \\
\hline SABIC UK Petrochemicals Ltd & Teesside, UK & A wholly owned affiliate of SABIC & $\begin{array}{c}\text { Ethylene, propylene, benzene cyclohexane, } \\
\text { cracked distillate hydrogen, butadiene, } \\
\text { polyethylene (LDPE) }\end{array}$ \\
\hline SABIC Polyolefine GmbH & Gelsenkirchen, Germany & A wholly owned affiliate of SABIC & $\begin{array}{c}\text { Polyethylenes (HDPE, LLDPE) and } \\
\text { polypropylene }\end{array}$ \\
\hline $\begin{array}{l}\text { SAMAC Saudi Methyl Acrylate } \\
\text { Company }\end{array}$ & Al-Jubail, Saudi Arabia & $\begin{array}{l}\text { A 50/50 joint venture with Mitsubishi } \\
\text { Rayon Company }\end{array}$ & $\begin{array}{c}\text { Methyl Methacrylate (MMA), } \\
\text { polymethylmethacrylate (PMMA) }\end{array}$ \\
\hline $\begin{array}{l}\text { SINOPEC SABIC Tianjin } \\
\text { Petrochemical Co. Ltd. }\end{array}$ & Tianjin, China & $\begin{array}{c}\text { A 50/50 joint-venture between SABIC } \\
\text { Industrial Investments Company and } \\
\text { SINOPEC (China Petroleum \& Chemical } \\
\text { Corporation) }\end{array}$ & $\begin{array}{l}\text { Ethylene, propylene, polyethylene (HDPE, } \\
\text { LLDPE), polypropylene, ethylene oxide, } \\
\text { MEG, DEG, phenol, acetone, MTBE, } \\
\text { butadiene, and butene-1 }\end{array}$ \\
\hline $\begin{array}{l}\text { Saudi Kayan Saudi Kayan } \\
\text { Petrochemical Company }\end{array}$ & Al-Jubail, Saudi Arabia & SABIC (35\%), public shareholders (65\%) & $\begin{array}{c}\text { Ethylene, propylene, polypropylene, LDPE, } \\
\text { HDPE, ethylene glycol, acetone, } \\
\text { polycarbonate (PC), ethanolamines (EOA), } \\
\text { ethoxylates, bisphenol A, benzene, normal } \\
\text { butanol, and natural-detergent alcohol } \\
\text { (NDA) }\end{array}$ \\
\hline $\begin{array}{l}\text { Sharq Eastern Petrochemical } \\
\text { Company }\end{array}$ & Al-Jubail, Saudi Arabia & $\begin{array}{l}\text { A } 50 / 50 \text { SABIC joint-venture with a } \\
\text { consortium of Japanese companies led } \\
\text { by Mitsubishi Corporation }\end{array}$ & $\begin{array}{l}\text { Ethylene, propylene, aromatics (BTX), } \\
\text { ethylene glycol (mono, di, tri), linear low- } \\
\text { density polyethylene (LLDPE), and high- } \\
\text { density polyethylene (HDPE) }\end{array}$ \\
\hline $\begin{array}{l}\text { Shrouq Saudi Japanese } \\
\text { Acrylonitrile Company }\end{array}$ & Al-Jubail, Saudi Arabia & $\begin{array}{c}\text { SABIC }(50 \%) \text {, ASAHI Kasei Chemicals } \\
\text { Corporation }(30 \%) \text { and Mitsubishi } \\
\text { Corporation (20\%) }\end{array}$ & Chemicals \\
\hline $\begin{array}{l}\text { SOCC Saudi Organometallic } \\
\text { Chemicals Company }\end{array}$ & Al-Jubail, Saudi Arabia & $\begin{array}{l}\text { A 50/50 joint-venture between Saudi } \\
\text { Specialty Chemicals Company and } \\
\text { Albemarle Netherlands BV }\end{array}$ & Tri-ethyl aluminum (TEAL) \\
\hline $\begin{array}{l}\text { Specialty Chem Saudi Specialty } \\
\text { Chemicals Company }\end{array}$ & Al-Jubail, Saudi Arabia & $\begin{array}{c}\text { Wholly owned affiliate of SABIC (Arabian } \\
\text { Petrochemical Company - Petrokemya, } \\
99 \% \text {, and SABIC Industrial Investments } \\
\text { Company 1\%) }\end{array}$ & $\begin{array}{l}\text { Tri-ethyl aluminum (TEAL), TPO/PP } \\
\text { compounds, PC compounds, ABS } \\
\text { compounds, and specialty products }\end{array}$ \\
\hline $\begin{array}{l}\text { United Jubail United } \\
\text { Petrochemical Company }\end{array}$ & Al-Jubail, Saudi Arabia & $\begin{array}{c}\text { SABIC (75\%), Pension Fund (15\%), } \\
\text { General Organization of Social Insurance } \\
(10 \%)\end{array}$ & $\begin{array}{c}\text { Ethylene, polyethylene, ethylene glycol (EG), } \\
\text { and linear-alpha olefins (LAO) }\end{array}$ \\
\hline $\begin{array}{l}\text { Yanpet Saudi Yanbu } \\
\text { Petrochemical Company }\end{array}$ & Yanbu, Saudi Arabia & $\begin{array}{l}\text { A 50/50 SABIC joint-venture with Mobil } \\
\text { Yanbu Petrochemical Company (an } \\
\text { affiliate of ExxonMobil Chemical, USA) }\end{array}$ & $\begin{array}{c}\text { Ethylene, polyethylene, ethylene glycol, } \\
\text { polypropylene, pyrolysis gasoline, and } \\
\text { propylene }\end{array}$ \\
\hline $\begin{array}{l}\text { Yansab Yanbu National } \\
\text { Petrochemical Company }\end{array}$ & Yanbu, Saudi Arabia & $\begin{array}{l}\text { SABIC (51\%), public shareholders or } \\
\text { owned by others }(49 \%)\end{array}$ & $\begin{array}{c}\text { Ethylene, propylene, ethylene glycol (mono, } \\
\text { di, tri), linear low-density polyethylene } \\
\text { (LLDPE), high-density polyethylene (HDPE), } \\
\text { polypropylene, butene- } 1 \text {, butene-2, } \\
\text { benzene, toluene/ xylene mixture, and } \\
\text { MTBE }\end{array}$ \\
\hline
\end{tabular}




\section{Saudi Binladin Group:}

\begin{tabular}{|c|c|}
\hline Projects & Country \\
\hline Sharm El-Sheikh Airport & Egypt \\
\hline Hotel Four Seasons Amman & Jordan \\
\hline Kuala Lumpur Airport & Malaysia \\
\hline Kuala Lumpur Airport & Malaysia \\
\hline Putra Jaya Mosque & Malaysia \\
\hline Doha Airport & Qatar \\
\hline Al Shuaiba Power Plant & Saudi Arabia \\
\hline BCS Ready Mix Factory & Saudi Arabia \\
\hline BCS Ready Mix Factory & Saudi Arabia \\
\hline Bahra Industrial Complex & Saudi Arabia \\
\hline Bahra Industrial Complex & Saudi Arabia \\
\hline Bahra Industrial Complex & Saudi Arabia \\
\hline Bahra Industrial Complex & Saudi Arabia \\
\hline BCS Ready Mix Factory & Saudi Arabia \\
\hline BCS Ready Mix Factory & Saudi Arabia \\
\hline King Abdul Azeez International Airport & Saudi Arabia \\
\hline Makkah Holy Mosque Expansion & Saudi Arabia \\
\hline King Abdul Azeez Endowment Project & Saudi Arabia \\
\hline Holly Mosque Madeena & Saudi Arabia \\
\hline Al Qassim - Al Madina - Yanbu - Rabigh - Thuwal Express Way & Saudi Arabia \\
\hline $\begin{array}{c}\text { Al Hada Road - Halwani Bridge } \\
\end{array}$ & Saudi Arabia \\
\hline Al Mutamarat Under Pass & Saudi Arabia \\
\hline Hajj Terminal - KAIA & Saudi Arabia \\
\hline Jamarat Bridge & Saudi Arabia \\
\hline King Abdull Aziz Endowment & Saudi Arabia \\
\hline King Abullah Endowment - Madina & Saudi Arabia \\
\hline Internal Security Forces Housing - Jeddah & Saudi Arabia \\
\hline King Abdullah Financial District & Saudi Arabia \\
\hline Umm Al Qura University & Saudi Arabia \\
\hline V.I.P Military Hospital - Riyadh & Saudi Arabia \\
\hline Behra Industrial Complex & Saudi Arabia \\
\hline King Abdullah University for Science and Technology & Saudi Arabia \\
\hline Blaise Diagne International Airport, Dakar & Senegal. \\
\hline Sharjah International Airport & UAE \\
\hline Sharjah American University & UAE \\
\hline
\end{tabular}

Source: http://www.sbg.com.sa/ 


\begin{tabular}{|c|c|}
\hline Clients & Country \\
\hline Munshaat for Projects and Contracting Company & Saudi Arabia \\
\hline Rayadah Investment Company & Saudi Arabia \\
\hline Princess Nora Bint Abdul Rahman University & Saudi Arabia \\
\hline Saudi Arabian Monetary Agency (SAMA) & Saudi Arabia \\
\hline Ministry of Education & Saudi Arabia \\
\hline King Saud University & Saudi Arabia \\
\hline Egyptian Airports Company & Saudi Arabia \\
\hline Ministry of Foreign Affairs & Saudi Arabia \\
\hline Ministry of Defense & Saudi Arabia \\
\hline Ministry of Finance & Saudi Arabia \\
\hline Jeddah Municipality & Saudi Arabia \\
\hline Riyadh Military Hospital & Saudi Arabia \\
\hline King Abdullah Economic City & Saudi Arabia \\
\hline Saudi Aramco & Saudi Arabia \\
\hline $\begin{array}{c}\text { EMAAR Properties } \\
\end{array}$ & Saudi Arabia \\
\hline Hadramout University of Science and Technology & Saudi Arabia \\
\hline Department of Civil Aviation Authority - Government Dubai & UAE \\
\hline $\begin{array}{c}\text { EMAAR Properties } \\
\end{array}$ & UAE \\
\hline Dubai Internet City (TECOM) & UAE \\
\hline Sharjah Airport Authority & UAE \\
\hline Majid Al Futtaim & UAE \\
\hline TECOM Investments & UAE \\
\hline Dubai Lifestyle City L.L.C. & UAE \\
\hline SAMA Dubai & UAE \\
\hline MIZIN & UAE \\
\hline Dubai Municipality & UAE \\
\hline Legend Middle East & UAE \\
\hline Roads and Transport Authority & UAE \\
\hline Republic of Yemen & Yemen \\
\hline Damascus Governorate & Syria \\
\hline Khalifa Bin Zayed Al Nahyan Foundation & Syria \\
\hline Majid Al Futtaim Group & Syria \\
\hline Construction Products Holding Company & Syria \\
\hline EMAAR-IGO & Syria \\
\hline Egyptian Airports Company & Egypt \\
\hline Kuala Lumpur International Airport & Malasyia \\
\hline
\end{tabular}

Source: http://www.sbgpbad.ae/ 


\begin{tabular}{|c|c|c|c|}
\hline Sector & Partner & Sector & Partner \\
\hline \multirow[t]{9}{*}{ Al-Futtaim Motors } & Toyota & Joint Ventures & Honda (Oman) \\
\hline & Lexus & & Panasonic (Oman) \\
\hline & Volvo & & GE (Oman) \\
\hline & Hunda & & Black \& Decker (Oman) \\
\hline & Chrysler & & BPL(Oman) \\
\hline & Jeep & & Aftron (Oman) \\
\hline & Dodge & & Raymond Well (Uman) \\
\hline & Hertz & & Alba (Oman) \\
\hline & & & Westar (Oman) \\
\hline \multirow[t]{5}{*}{ Electronics \& Engineering Bussiness Division } & Panasonic & & Kolber (Oman) \\
\hline & Toshiba & & Culligan Water Plants (Oman) \\
\hline & Afcomp & & Dow Chemical Products (Oman) \\
\hline & Sanyo & & Esso/Adnoc Lubricants (Oman) \\
\hline & & & Yanmar (Qater) \\
\hline \multirow[t]{19}{*}{ Retailing \& Services } & IKEA & & Volvo (Qatar) \\
\hline & Japan Airlines & & Hona (Qatar) \\
\hline & IBM & & Raymond Weil (Qater) \\
\hline & Raymond Weil & & Westar (Qater) \\
\hline & Seiko & & Titan (Qater) \\
\hline & Kolber (the brand & & Kolber (Qater) \\
\hline & owned by group, & & Casino Watches (Qater) \\
\hline & made in & & Sanyo (Qater) \\
\hline & Swisserland) & & Aftron (Qater) \\
\hline & Fossil & & Acson (Qatar) \\
\hline & Alba & & Akira (Qatar) \\
\hline & Delma & & Carlllion Construction of the UK \\
\hline & Westar & & Honda (Egypt) \\
\hline & Esprit & & Yanmar (Egypt) \\
\hline & Nanis & & Toyo Tyres (Egypt) \\
\hline & & & Hino Trucks and Busses (Egypt) \\
\hline & Diamond Jewellery. & & Toyota (Foynt) \\
\hline & Tanzanite & & Fiat (Pakistan) \\
\hline & & & Case New Holland (Pakistan) \\
\hline \multirow[t]{3}{*}{ Insurance \& Overseas } & Willis Group & & Tarmac Construction of the UK \\
\hline & Tokio Marine & & Ajman Government \\
\hline & Fire Insurance & & Keppel Corporation of Singapore \\
\hline
\end{tabular}




\begin{tabular}{|c|c|c|}
\hline & Client & \begin{tabular}{|l} 
Project \\
\end{tabular} \\
\hline \multirow{10}{*}{ FPSO } & Saipem Energy Services SpA & $\begin{array}{l}\text { Tanker Betatank II to FPSO } \\
\text { Firenze }\end{array}$ \\
\hline & Saipem SpA for Sonangol & VLCC Magdeline to FPSO Gimboa \\
\hline & Saipem SpA for Petrobras & $\begin{array}{l}\text { VLCC Margaux to FPSO Cidade de } \\
\text { Vitoria }\end{array}$ \\
\hline & SBM IMODCO for Chevron & VLCC Lu San to FPSO Frade \\
\hline & $\begin{array}{l}\text { SBM Offshore N.V. and } \\
\text { Sonangol for Exxon Mobil } \\
\text { Corporation }\end{array}$ & $\begin{array}{l}\text { VLCC Mosocean into FPSO } \\
\text { Xikomba }\end{array}$ \\
\hline & Single Buoy Moorings Inc. & $\begin{array}{l}\text { Conventional VLCC to FPSO } \\
\text { Atlantic } \\
\text { Conventional Crude Carrier Stena } \\
\text { Contender to FSO Nkossa1 }\end{array}$ \\
\hline & $\begin{array}{l}\text { Saipem, ENI/Single Buoy } \\
\text { Moorings Inc. }\end{array}$ & $\begin{array}{l}\text { Conventional medium size crude } \\
\text { tanker to FPSO Mystras II }\end{array}$ \\
\hline & $\begin{array}{l}\text { Fred Olsen Production AS for } \\
\text { Canadian Natural Resources } \\
\text { Limited }\end{array}$ & VLCC to FPSO Knock Allan \\
\hline & $\begin{array}{l}\text { Fred Olsen Production A.S. for } \\
\text { Addax Petroleum and Sinopec }\end{array}$ & $\begin{array}{l}\text { VLCC Elgreco to FPSO Knock } \\
\text { Adoon }\end{array}$ \\
\hline & FPSOcean & $\begin{array}{l}\text { Shuttle tanker to FPSO Deep } \\
\text { Producer I }\end{array}$ \\
\hline \multirow{5}{*}{ FSO } & $\begin{array}{l}\text { Red Band Inc., Fred.Olsen } \\
\text { Production A.S. for Maersk Oil }\end{array}$ & $\begin{array}{l}\text { World's largest tanker T/T Jahre } \\
\text { Viking to FSO Knock Nevis }\end{array}$ \\
\hline & Mercator Lines & Tanker to FSO Prem Pride \\
\hline & $\begin{array}{l}\text { Teekay Shipping (Norway) As } \\
\text { for Occidental Petroleum } \\
\text { Corporation }\end{array}$ & $\begin{array}{l}\text { Shuttle tanker to FSO Falcon } \\
\text { Spirit }\end{array}$ \\
\hline & $\begin{array}{l}\text { EuroNav and Overseas } \\
\text { Shipholding Group for Maersk }\end{array}$ & $\begin{array}{l}\text { ULCC TI Asia to FSO Asia } \\
\text { ULCC TI Africa to FSO Africa }\end{array}$ \\
\hline & $\begin{array}{l}\text { BW Offshore for Murmansk } \\
\text { Commercial Seaport }\end{array}$ & Tanker to FSO Berge Pioneer \\
\hline FSRU & $\begin{array}{l}\text { Saipem SpA for Offshore LNG } \\
\text { Toscana }\end{array}$ & $\begin{array}{l}\text { LNG carrier Golar Frost to FSRU } \\
\text { Toscana }\end{array}$ \\
\hline \multirow{5}{*}{ Others } & Teekay Marine Service AS & $\begin{array}{l}\text { Suezmax conventional oil tanker } \\
\text { to Shuttle tanker Navion } \\
\text { Gothenburg } \\
\text { Aframax conventional oil tanker } \\
\text { to Shuttle tanker Navion Bergen }\end{array}$ \\
\hline & $\begin{array}{l}\text { Consortium comprising of } \\
\text { Woodside Energy Ltd., Shell } \\
\text { International, BHP, BP Amoco, } \\
\text { Chevron and } \\
\text { Mitsui/Mitsubishi }\end{array}$ & Upgrade of FPSO Cossack Pioneer \\
\hline & Scandic Shipmanagement & Modification of Golden Arrow - I \\
\hline & Saipem Sp.A. & Upgrading DLB Castoro 2 \\
\hline & Torvald Klaveness & $\begin{array}{l}\text { Gearless panamax bulk carrier } \\
\text { Balsfjord to self Un-loader vessel }\end{array}$ \\
\hline
\end{tabular}

Source: http://www.al-futtaim.ae/content/organigram.asp 
Dubai World (Subsidiaries)

\begin{tabular}{|c|c|}
\hline DP World & Marine Terminals \\
\hline Bussinesses & World Crane Services \\
\hline & DP World Cargo Services \\
\hline & $\begin{array}{c}\text { Container Rail Road Services Private } \\
\text { Limited }\end{array}$ \\
\hline $\begin{array}{c}\text { Financial } \\
\text { Partnerships }\end{array}$ & $\begin{array}{c}\text { Dubai International Financial Center } \\
\text { (DIFC) }\end{array}$ \\
\hline & Dubai Financial Services Authority \\
\hline & NASDAQ Dubai \\
\hline & UK Financial Conduct Authority (FCA) \\
\hline & $\begin{array}{c}\text { Corporate Governance principles of the } \\
\text { UK }\end{array}$ \\
\hline & Corporate Governance Code (the Code) \\
\hline & NASDAQ OMX Group \\
\hline
\end{tabular}

Source: http://www.drydocks.gov.ae/en/portal/orfcus.ofshre.aspx 


\section{Istihmar World}

\begin{tabular}{|c|c|c|}
\hline Bussiness Entity & Sector & Location \\
\hline AL BURJ & Hospitality \& Real Estate & UAE \\
\hline Barneys Newyork & Consumer & US \\
\hline Bubye & Hospitality \& Real Estate & South Africa \\
\hline Cirque Du Soleil & Consumer & Canada \\
\hline Czech Techo Park Brno & Hospitality \& Real Estate & Czech Republic \\
\hline Djibouti Palace Kempinski & Hospitality \& Real Estate & Djibouti \\
\hline Dubai Aerospace Enterprise & Industrial \& Business Services & UAE \\
\hline DW Travel & Consumer & UAE \\
\hline FORSA & Hospitality \& Real Estate & UAE \\
\hline Gorillas' Nest Lodge & Hospitality \& Real Estate & Rwanda \\
\hline Gulf African Bank & Financial Services & Kenya \\
\hline Hans Energy & Industrial \& Business Services & HK/China \\
\hline IHI Plc & Hospitality \& Real Estate & Malta \\
\hline Inchcape Shipping Services & Industrial \& Business Services & UK \\
\hline Intex Shanghai & Hospitality \& Real Estate & China \\
\hline Jock Safari Lodge & Hospitality \& Real Estate & South Africa \\
\hline Kerzner & Hospitality \& Real Estate & Asia \\
\hline Mazagan Beach Resort & Hospitality \& Real Estate & Morocco \\
\hline Nyungwe Park & Hospitality \& Real Estate & Rwanda \\
\hline One\&Only Palmilla & Hospitality \& Real Estate & Mexico \\
\hline Padaeng Industry PLC & Industrial \& Business Services & Thailand \\
\hline Pension Insurance Corporation & Financial Services & UK \\
\hline Perella Weinberg Partners & Financial Services & US \\
\hline Retailcorp Brands & Consumer & UAE \\
\hline Sanbona Wildlife Reserve & Hospitality \& Real Estate & South Africa \\
\hline Shamwari Game Reserve & Hospitality \& Real Estate & South Africa \\
\hline Tejari & Industrial \& Business Services & UAE \\
\hline W Bangkok & Hospitality \& Real Estate & Thailand \\
\hline W Koh Samui & Hospitality \& Real Estate & Thailand \\
\hline
\end{tabular}

Source:

http://www.istithmarworld.com/index/index.php?option=com_content $\& v i e w=a r t i c l e \& i d$ $=208 \&$ Itemid $=226$ 
Economic Zones World: Jafza, TechnoPark, Dubai Auto Zone (re-exporting used cars to the Asia and Africa).

\section{TechnoPark}

\begin{tabular}{|c|}
\hline Research Partners \\
\hline Fraunhofer-Gesellschaft (FhG) \\
Boston University \\
\hline Arab Science and Technology Foundation (ASTF) \\
\hline Middle East Desalinations Centre (MEDRC) \\
\hline DAEDEOK INNOPOLIS \\
\hline DAEJEON TECHNOPARK \\
\hline Networking Partners \\
\hline World Association of Industrial and Technological Research \\
Organizations (WAITRO) \\
\hline International Network for Small and Medium Sized Enterprises \\
(INSME)
\end{tabular}

Source: http://www.ezw.ae/en/ducamz/dubai-auto-zone-ducamz.html 


\section{Kanoo Group}

\begin{tabular}{|c|c|c|}
\hline Subsidiaries & Partnership & Type of EconomciTie \\
\hline Middle East Container Repair & U.A.S.C, P.O Nedlloyd, Maersk, Hapag Lloyd and Uniglory, Plus many other lines & Client \\
\hline AXA Gulf & Axa Insurance Company & Partnership \\
\hline AkzoNobel & Dulux, Sikkens, International and Eka & Portfolio \\
\hline Freightworks & Emirates/DNATA & Joint Venture \\
\hline BASF Kanoo Gulf & MASDAR (Abu Dhabi Future Energy Company) & Partnership \\
\hline BASF Kanoo Gulf & Elastogran & Joint Venture \\
\hline BASF Kanoo Gulf & $\begin{array}{l}\text { The Eastern Europe, Africa and Western Asia Region (LR) changes its organizational } \\
\text { structure on April 1, 2000. The major new development is that regional Business Centers } \\
\text { are set up in the cities of Istanbul, Johannesburg, Dubai, Moscow and Ludwigshafen. } \\
\text { BASF's representatives in Algeria, Egypt, Dubai, Iran, Morocco and Tunisia are served by } \\
\text { Business Center Dubaai. BASF FZE in Dubai is founded as a service platform (sales } \\
\text { company) for the Middle East and North Africa. }\end{array}$ & \\
\hline Hydroturf & Doha Golf Course in Qatar & Mega Project \\
\hline Hydroturf & Shangri-laâat's Barr Al Jissah & Mega Project \\
\hline Hydroturf & Resort and Spa, Muscat, Oman & Mega Project \\
\hline Hydroturf & Tower Links Golf Course, & Mega Project \\
\hline Hydroturf & Ras Al Khaimah & Mega Project \\
\hline Hydroturf & Doha Asian Olympic Games, Qatar & Mega Project \\
\hline Hydroturf & Jumeirah Golf Estates, Dubai & Mega Project \\
\hline Hydroturf & Katameya Heights and Dunes, Cairo, Egypt & Mega Project \\
\hline Hydroturf & Saadiyat Island, Abu Dhabi & Mega Project \\
\hline Hydroturf & Dubai International Airport,Dubai & Mega Project \\
\hline Hydroturf & King Abdullah Economic City, Jeddah, Saudi Arabia & Mega Project \\
\hline Hydroturf & Madinat Jumeirah, Dubai & Mega Project \\
\hline Crane Industrial Services & Konecranes & Joint Venture \\
\hline Johnson Arabia & Charilaos Apostolides & Joint Venture \\
\hline Maersk Kanoo & Maersk Line & Joint Venture \\
\hline Chapo Kanoo & Charilaos Apostolides & Joint Venture \\
\hline OBAIKAN & OITC group, Qatar & Joint Venture \\
\hline Kanoo Group (SDV) & bolloré group & Joint Venture \\
\hline Kanoo Group (Mol, UAE) & MOL Group & Joint Venture \\
\hline Kanoo Group & Royal Ahrend & Joint Venture \\
\hline
\end{tabular}

Source: http://www.kanoogroup.com/ 


\section{Fakhro Group}

\begin{tabular}{|c|c|}
\hline subsidiaries & Business Partners \\
\hline $\begin{array}{l}\text { Abdulla Yousif } \\
\text { Fakhro and } \\
\text { Sons BSC(c) }\end{array}$ & $\begin{array}{l}\text { Dunlop tyres, Mobil lubricants, Dunlop industrial hoses, Dunlop } \\
\text { oil \& marine hoses, Dunlop conveyor belting, Omia spray } \\
\text { booths and workshop equipment, American Life Insurance Co. } \\
\text { (Alico) }\end{array}$ \\
\hline $\begin{array}{c}\text { Fakhro } \\
\text { Electronics }\end{array}$ & Sony, LG and $\mathrm{OKI}, \mathrm{Cisco}, 3 \mathrm{Com}$, Anritsu \\
\hline $\begin{array}{c}\text { Fakhro } \\
\text { Communication } \\
\mathrm{s}\end{array}$ & Ericsson and distributes products from Avaya, Aastra, Softex \\
\hline $\begin{array}{c}\text { ATCOM } \\
\text { (UAE) }\end{array}$ & Aastra (Dubai), Softex (Abu Dhabi), Avaya (Qatar) \\
\hline GAC Bahrain & GAC Group from Sweden \\
\hline $\begin{array}{l}\text { Fakhro } \\
\text { Restaurants } \\
\text { Company } \\
\text { (McDonald's) }\end{array}$ & McDonald \\
\hline \begin{tabular}{c|} 
Fakhro \\
Transport \\
(Budget Rent A \\
Car)
\end{tabular} & Budget \\
\hline \multirow{5}{*}{$\begin{array}{c}\text { Fakhro } \\
\text { Commercial } \\
\text { Services }\end{array}$} & MK Electric Co., UK \\
\hline & Brand Rex Ltd., UK \\
\hline & Morley IAS, UK \\
\hline & Honeywell \\
\hline & $\mathrm{ABB}$, Germany \\
\hline $\begin{array}{c}\text { Fakhro } \\
\text { Insurance } \\
\text { Services } \\
\end{array}$ & General Accident Insurance \\
\hline \multicolumn{2}{|l|}{ Go International } \\
\hline $\begin{array}{c}\text { CompuMe } \\
\text { Bahrain } \\
\end{array}$ & NA (products from the world's leading suppliers.) \\
\hline Fakhro Motors & BYD, Dongfeng \\
\hline
\end{tabular}

Source: http://www.fakhro.com/ 


\section{References:}

1. Beblawi, H. (1987). The rentier state in the Arab world. Arab Studies Quarterly, 383398.

2. Cox, Ronald. W. (1996). Business and the state in international relations. Westview Pr.

3. Cox, Ronald. W. (Ed.).(2012). Corporate Power and Globalization in US Foreign Policy (Vol.15).Routledge.

4. Cox, Ronald. W., \& Skidmore-Hess, D. (1999). US Politics and the Global Economy: Corporate Power, Conservative Shift. Lynne Rienner Publishers.

5. Dailami, M. (1999). Financial openness, democracy, and redistributive policy. World Bank Policy Research Working Paper, (2372).

6. Dailami, M. (2000). Financial openness, democracy, and redistributive policy(Vol. 2372). World Bank Publications.

7. Decisions." OPEC Review 4, no. 4 (1980): 97-121.

8. Ehrlich, Everett M. "Structural Change in Opec Member Country Production

9. Field, M. (1985). The Merchants: The Big Business Families of Saudi Arabia and the Gulf States. Overlook Pr

10. Gause, F. G. (1994). Oil monarchies: domestic and security challenges in the Arab Gulf states. Council on Foreign Relations.

11. Hanieh, A. (2011). Capitalism and class in the Gulf Arab states. Palgrave Macmillan.

12. Harvey, D. (2003). The new imperialism. Oxford University Press.

13. Heep, S. (2014). China in global finance: domestic financial repression and international financial power. Springer Science \& Business Media.

14. Hertog, S., Luciani, G., \& Valeri, M. (Eds.). (2013). Business politics in the Middle East. Hurst Publishers.

15. Heydarian, R. J. (2014). How capitalism failed the Arab world: the economic roots and precarious future of Middle East uprisings.

16. Inkpen, A. C., \& Moffett, M. H. (2011). The Global Oil \& Gas Industry: Management, Strategy \& Finance. PennWell Books. 
17. Kotz, D. M., \& McDonough, T. (2010). Global neoliberalism and the contemporary social structure of accumulation. Contemporary capitalism and its crises: Social structure of accumulation theory for the 21st century, 93-120.

18. Marcel, V. (2006). Oil titans: National oil companies in the Middle East. Brookings Institution Press.

19. Shekhar, K. C. (2009). Banking Theory And Practice, 19E. Vikas Publishing House PVT Ltd.

20. Robinson, W. I. (1996). Promoting polyarchy: globalization, US intervention, and hegemony (Vol. 48). Cambridge University Press.

21. Robinson, W. I. (2001). Social theory and globalization: The rise of a transnational state. Theory and Society, 30(2), 157-200.

22. Robinson, W. I. (2014). Global Capitalism and the Crisis of Humanity. Cambridge University Press.

23. Robinson, W. I., \& Harris, J. (2000). Towards a global ruling class? Globalization and the transnational capitalist class. Science \& Society, 11-54.

24. Rush, A. (1987). Al-Sabah: History \& Genealogy of Kuwait's Ruling Family, 17521987. Garnet \& Ithaca Press.

25. Sabri, S. (2001). The House of Saud in commerce: A study of royal entrepreneurship in Saudi Arabia. Sharaf Sabri.

26. Sauvant, K. P., Sachs, L. E., \&Jongbloed, W. P. S. (Eds.). (2012). Sovereign investment: Concerns and policy reactions. Oxford University Press.

27. Sklair, L. (1998). Transnational practices and the analysis of the global system(pp. pp18). University of Oxford. Transnational Communities Programme.

28. Sklair, L. (2000). The transnational capitalist class and the discourse of globalisation. Cambridge Review of International Affairs, 14(1), 67-85.

29. Sklair, Leslie. "The transnational capitalist class and the discourse of globalisation." Cambridge Review of International Affairs 14.1 (2000): 67-85.

30. Stiglitz, J. E. (2010). Freefall: America, free markets, and the sinking of the world economy. WW Norton \& Company. 
Other Resources:

1. http://www.virginia.edu/igpr/APAG/apagoilcompany.html

2. http://www.bp.com/content/dam/bp/pdf/Energy-economics/statistical-review2015/bp-statistical-review-of-world-energy-2015-full-report.pdf

3. http://www.arabianoilandgas.com/article-4890-shell--seven-decades-in-ksa/

4. BMI Company Analysis Reports, 4/2009, Lexus and Nexus

5. http://www.gulfbase.com/gcc/aboutgcc?pageid=93

6. http://www.gulfbase.com/gcc/aboutgcc?pageid=93

7. http://www.fakhro.com/

8. http://kanoo.com/partners/kanoo_property.aspx

9. http://kanoo.com/partners/maersk.aspx

10. http://www.nytimes.com/2001/10/26/business/bin-laden-family-liquidates-holdingswith- carlyle-group.html

11. http://www.gulfbase.com/gcc/aboutgcc?pageid=93

12. http://www.counterpunch.org/2009/03/13/is-this-really-the-end-of-neoliberalism/

13. http://www.opensecrets.org/

14. http://www.imf.org/external/pubs/ft/scr/2014/cr14292.pdf

15. http://www.dbresearch.com/PROD/DBR_INTERNET_ENPROD/PROD0000000000296909/GCC+financial+markets\%3A+Longterm+prospects+for+finance+in+the+Gulf+region.PDF

16. http://data.worldbank.org/indicator/

17. https://www.imf.org/external/np/sec/pr/1997/PR9705.HTM 


\section{CHAPTER IV}

\section{MILITARIZATION OF GCC TRANSNATIONAL SPACE: CHARACTERISTICS AND IMPLICATIONS}

\section{Introduction}

GCC militarization is rooted in the socioeconomic class structure of the region that is specifically designed to protect the interests of the GCC capitalist class against internal instability and threats. At the same time, the militarization strengthens the economic ties between GCC elites/states and the TCC. To fully understand this militarization in its current phase, this chapter is divided into two parts. The first part explains the military structure of GCC and how it has evolved due to a number of notable historical events. The second part explains the target of this focus on military and security power. This focus can be analyzed based on domestic objectives, regional goals, and, to a lesser extent, global aspirations.

Analyzing the militarization of the Persian Gulf region is an integral part of this dissertation because GCC militarization is one of the essential components of the GCC economic transnationalization and the embeddedness of GCC elites within the TCC. According to Askari et al, "[t]he Persian Gulf is, by some indicators, the most militarized region in the world. Public dissatisfaction with economic and social progress and the absence of elective legitimacy has led rulers and governments to rely on force to maintain power" (Askari et al, 2010, P. 3, footnote omitted). The Global Militarization Index (GMI) indicates that, on average, the GCC states (except Qatar for which no data was available 
in 2014), are among the top 17 percent of most militarized states (out of 154) in the world $^{23}$.

In this chapter, I will attempt to explain such immense militarization based on a class- based analytical framework and show how this militarization is merely part of a broader class- based project that includes the protection of both domestic GCC interests and wider TCC interests in the Persian Gulf. The militarization of the Persian Gulf is based on a series of historical circumstances. A traditional explanation focuses on the significant role of oil and the demand of actors in the global political economy to have secure access to GCC oil supplies. Accordingly, from the early days of the Cold War the international energy order was organized around Middle Eastern oil production and enjoyed U.S. military and security protection. More recent evidence suggests that the international energy order is more fragmented than what the traditional perspective suggests. On one hand, with the rise of China and Russia the world economy is witnessing new powerful capitalist economies with important, albeit different, impacts on the global energy order. On the other hand, the other regions including the Caspian Sea region, Latin America and North America, and Africa are becoming more important players in the global oil supply. Many parts of these regions, especially in the Caspian Sea and African oil rich regions, have been militarized, lending support to the traditional argument that oil plays a significant role in militarization.

\footnotetext{
${ }^{23} \mathrm{http} / / /$ gmi.bicc.de/index.php?page=ranking-table\&year=2013\&sort=rank_asc
} 
Along with these global changes, the militarization of the Persian Gulf region has also intensified dramatically during the past decades. From a state-centric perspective, there may be different reasons for states to increase their military expenditures. Historically, military expenditure is believed to increase based on the level of perceived threats by different states (Smith, 1980). Military expenditure by one state can also be in reaction to the increase of military expenditure by a neighboring state or states (Dune \& Perlo, 2003). In addition, particular cultural and/or ideological aspects of state policymaking also influence the level of military expenditure (Payne, 1989). Another significant factor is the militarization of U.S. foreign policy, a structural shift that refers to the use of military power instead of diplomacy in foreign policy. This shift has had cascading effects across the globe. In terms of U.S. foreign policy, a large body of literature on militarization of the Persian Gulf focuses on the direct relationship between the U.S. militarization and the desire to have secure access to Persian Gulf oil (Bacevich 2013, Klare 1978).

Despite the fact that the share of U.S. crude oil imports from the Middle East in general has constantly decreased over the past decades, the amount of U.S. oil imported from Saudi Arabia has not significantly changed. In 1993, the U.S. crude oil import from Saudi Arabia was 467,753 thousands of barrels; in 2014 it was 423,066 thousands of barrels ${ }^{24}$. At the same time, around a quarter of global oil supply was still being transferred through the Strait of Hormuz, over which tension arises occasionally given the adverse

\footnotetext{
${ }^{24}$ http://www.eia.gov/dnav/pet/pet_move_impcus_a2_nus_epc0_im0_mbbl_a.htm
} 
relationship between Iran, on the one hand, and the United States and most Persian Gulf Arab countries on the other. Therefore, oil is still an important reason for militarization of the Persian Gulf region. So, I agree that the region's militarization is partly - but only partly - rooted in U.S. Demand for Middle Eastern oil. However, reducing the current phase of the militarization of the region merely the U.S. need for secure oil supplies is an unwarranted analytical jump. This chapter, therefore, aims to analyze a less-discussed aspect of militarization of the Persian Gulf region: the class-based dimension of the current GCC militarization. This class-based dimension, however, directly intersects with the traditional arguments briefly discussed above.

While important scholarly contributions have been made by the traditional approaches, I believe that a class-based explanation of the militarization in this particular region would help generate a more comprehensive explanation of many other aspects of the phenomenon.

\section{The Pattern of GCC Military Expenditure}

The business ties between the GCC and the TCC through the military spending of GCC states protect the emerging transnationalization of capital and the repressive state apparatus in the region, the latter of which acts to anticipate and to counter the inevitable economic, political and social polarization engendered by this type of capital accumulation. The GCC's military expenditure is comparable to that of the states with the highest military budgets in the world (excluding the exceptional case of the United States, of course). The below chart shows the military expenditure by state with the highest military expenses. In 2014, Saudi Arabia, itself, was ranked as the fourth largest military 
spender in the world, even though the country did not seem to face an imminent, notable threat to its national borders.

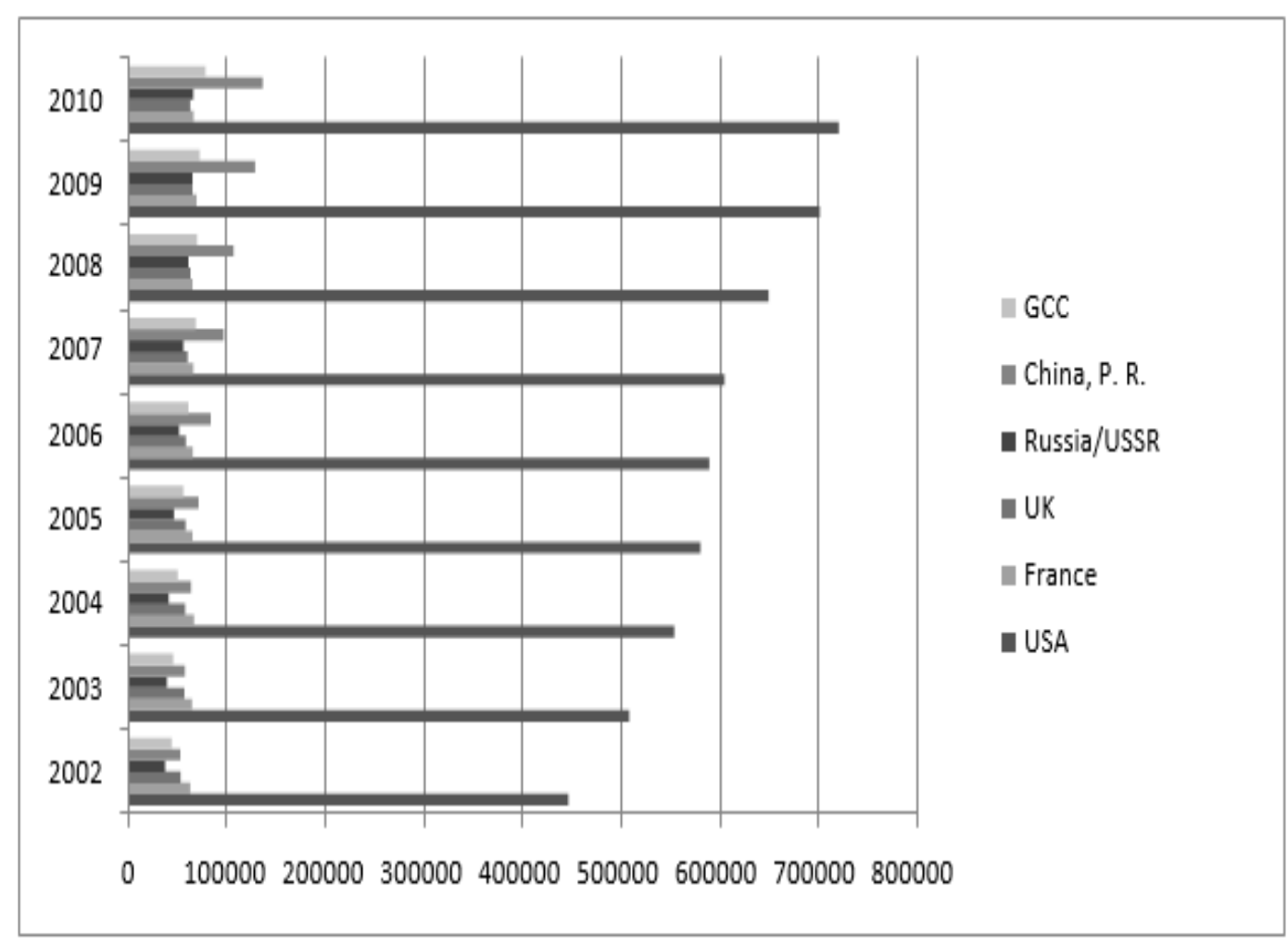

Chart 4: Top Military Spenders in the World

Source: Based on data available here:

http://www.sipri.org/research/armaments/milex/milex_database

Unlike other states listed in Chart 4, the GCC states seem to have more difficulty projecting their military power to shape external affairs. This is partly due to the weakness of GCC's soft power in general. Similar to other neoliberal economies, the GCC bloc lacks a strong nationally-oriented cultural or ideological base, and it is not clear what values the bloc represents. Two military engagements by Saudi Arabia confirm the limited reach of the GCC's huge military power. The first military engagement, the so-called Gulf War, was led by the United States in 1990 and 1991 in response to Iraq's conquest of Kuwait and the threat Iraq subsequently posed to Saudi Arabia's oil fields. The United States 
deployed "some 540,000 U.S. soldiers, sailors, airmen, and marines and their equipment to Saudi Arabia" (Shrader, 2009, P. 263). In addition to the leading role of the U.S. military, the coalition in that war included many other states, including Argentina, Australia, Belgium, Canada, Denmark, France, Greece, Italy, the Netherlands, Norway, Spain, and the United Kingdom (Tucker, 2014, P. 284). Saudi Arabia and other Gulf States were part of this coalition. Without the far-reaching support of the U.S. military and the broad coalition, there was arguably no chance for the GCC to restore Kuwaiti sovereignty and to end the Iraqi occupation, and the West's access to Saudi Arabia's oil reserves would have remained at risk.

The second case is the Saudi military invasion of Yemen to counter Houthi rebels in 2015. The Yemeni engagement is more critical for our purpose than the Gulf War. In Yemen, Saudi Arabia, after decades of purchasing some of the world's most advanced military equipment, attacked one of the most underdeveloped and weakest countries in the world. Nonetheless, despite its considerable technological advantages, the Saudi military has been relying on "U.S. help [for] planning air strikes on Houthi rebels in Yemen, in addition to logistical and intelligence support. ${ }^{25 "}$ Moreover, the Saudis had military support from other GCC states (except Oman), as well as from Egypt, Jordan, Morocco, Senegal, and even some sections of the Yemeni military. Despite the (im)balance of the military powers in the Yemeni case, however, the Saudi military has failed to deliver

\footnotetext{
${ }^{25} \mathrm{http}$ ://www.bloomberg.com/news/articles/2015-03-26/yemeni-bombing-led-by-saudis-isbacked-by-u- s-logistics-spying
} 
a clear and quick conclusion; and the war drags on causing considerable damage to Yemeni infrastructure and a drain on Saudi resources.

The limited ability of Saudi Arabia to project its military power exemplifies the general state of the military industry in the GCC. According to research on "[t]he Gulf Military Forces in an Era of Asymmetric War" conducted by the Center for Strategic and International Studies (CSIS):

"Saudi Arabia has long been dependent on other nations for virtually all of its arms and military technology. . . .It can produce some small arms, automatic weapons, and munitions, but much of the Saudi portion of the work consists of assembling imported parts rather than real manufactures. ${ }^{26} \ldots$ Saudi military forces are modern, high technology forces by regional standards, but manpower is a problem. Motivation, education, and training are, however, serious problems. ..."27 (pp. 13-19)

Similar to other economic and security sectors of the GCC's political economy, the considerable spending of the GCC in the military sector has not created a strong national military power that could act as an external deterrent. The avowed or perceived enemies of Saudi Arabia, for instance, do not seem to be particularly deterred by its military might. Instead, the military and security power of the GCC has been fairly successful in protecting the status quo for the royal families - a model that the Shah had pursued in Iran prior to 1979 Revolution. The GCC military and security power is to a great extent

\footnotetext{
${ }^{26}$ http://csis.org/files/media/csis/pubs/060728_gulf_saudi.pdf

${ }^{27}$ http://csis.org/files/media/csis/pubs/060728_gulf_saudi.pdf
} 
robust if one considers it as a protective shield for the transnational elites' class project: a project that aims at making the GCC an important node of transnational capital accumulation for the TCC (and also for GCC transnational elites themselves). It does not matter if the considerable military expenditures do not pay off on the battlefield in Yemen, Syria or other places; what matters is that the high spending on weapons act as a powerful vehicle to keep the GCC elites as an indispensable part of global TCC. The following figure shows the military-business ties of the GCC states with other countries.

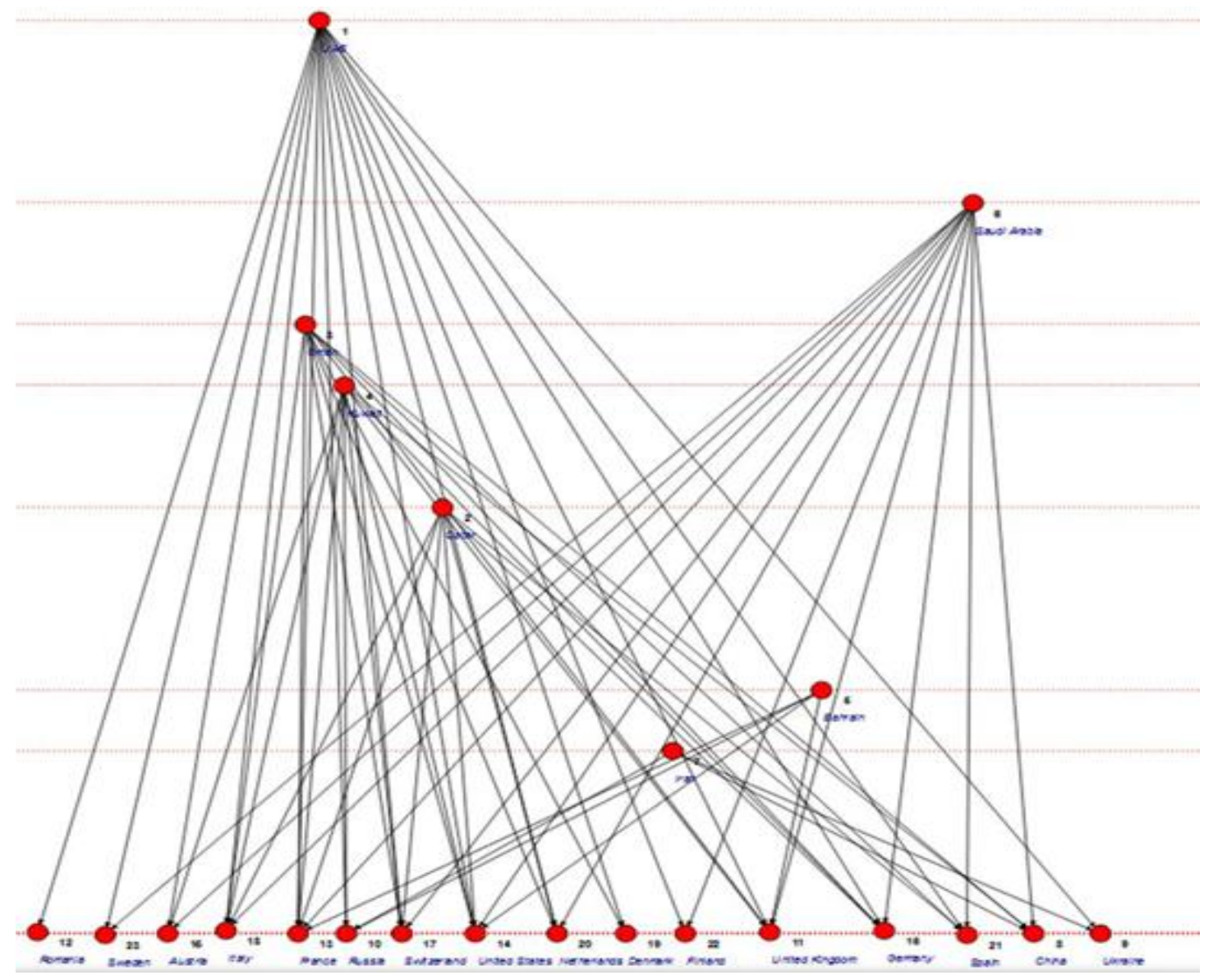

Figure 8: Military Deals by Persian Gulf States and The Sellers Source: Based on the data available here; http://csis.org/files/publication/150428_military_spending.pdf 
The GCC militarization is by and large a manifestation and expansion of emerging ties between the GCC transnational elites and TCC. In other words, this kind of militarization is part of the process that has embedded the GCC elites within in the TCC. The following parts of the chapter will further discuss this dynamic as well as the challenges that it has brought up for both the GCC elites and TCC.

\section{Militarization, Oil, and the Transformation of the Elite Network in the GCC}

Following the discovery of some of the largest oil fields in the world in Saudi Arabia at the beginning of the twentieth century, the Saudi royal family soon recognized the many opportunities and challenges before them. The economic ties between Saudi royal family, on the one hand, and Western states and multinational corporations (MNCs), on the other, are often traced back to the famous meeting between President Franklin Roosevelt and King Abdul Aziz of Saudi Arabia in 1945. It was Roosevelt who first structured an oil-based foreign policy towards Saudi Arabia, a foreign policy that later served as a blueprint for dealing with other GCC states. The key premise of this oil-based foreign policy is that the consequential geopolitical players in this region are the multinational oil corporations. Accordingly, strategies have been devised based on these corporations' interests and their business security. However, the emergence of GCC conglomerates and the rising power of the GCC royal families as well as that of merchant families also contributed to the domination of corporate interests in GCC-U.S. relations.

One of the key aspects of the meeting between Saudi King Abdul Aziz and President Roosevelt was the perceived U.S. guarantee of its permanent support to secure the Saudi royal family's position in return for secure access to Saudi oil fields. A pattern of dependency of the U.S. economy on Saudi oil began to emerge during the 1941-1945 
period, when Saudi Arabia provided "6 of the 7 billion barrels of oil that fueled the Allied forces in World War II [while] the United States consume[d] approximately $1 / 3$ of its known oil reserves." (Klare, 2008, P. 7) ${ }^{28}$. There is not much information about the nature and details of the agreements between Roosevelt and the Saudi King; but as for the significance of that meeting, it suffices to quote Dick Cheney:

"Our strategic interests in the Persian Gulf region, I think, are well-known but bear repeating today....We do, of course, have historic ties, especially to the Saudis, but other governments in the region, that hark back with respect to Saudi Arabia to 1945, when President Franklin D. Roosevelt met with King Abd al-Aziz on the USS Quincy towards the end of World War II and affirmed at that time that the United States had a lasting and continuing interest in the security of the Kingdom". ${ }^{29}$ (Klare, 2008, P. 5)

The meeting was also a starting point for strengthening the relationship between the GCC and TCC in the context of broader structural militarization. This structural militarization historically developed to protect energy security and access to oil. The domestic energy dependency of the West and GCC then pushed for further corporatization of this GCC-TCC relationship. On the Western side, and despite all its ups and downs, the dependency of Western industrial power on oil has never really ended. Oil remains a crucial resource for all aspects of the U.S economy. The U.S. domestic economy and U.S.-based American TNCs heavily depend on oil. At the same time, the US population

\footnotetext{
${ }^{28}$ http://www.mediaed.org/transcripts/Blood-and-Oil-Transcript.pdf

${ }^{29}$ http://www.mediaed.org/transcripts/Blood-and-Oil-Transcript.pdf
} 
comprises 4.5 percent of the world population, while its oil consumption accounts for more than 20 percent of global oil consumption (See Table 14). In addition to consumption within U.S. borders, U.S.-based TNCs produce oil in other parts of the world too, in particular in East Asian countries. This global chain of production consumes a considerable amount of oil each year. Despite all discussion of moving beyond oil into an era of renewable energies, the global economy remains by and large dependent on oil. What has changed, of course, is the relative significance of the Middle East in general and Saudi Arabia in particular in the global energy market.

\section{Domestic U.S. Dependency on Oil}

\begin{tabular}{|c|c|l|l|l|l|l|l|l|l|l|l|} 
& $\mathbf{2 0 0 4}$ & $\mathbf{2 0 0 5}$ & $\mathbf{2 0 0 6}$ & $\mathbf{2 0 0 7}$ & $\mathbf{2 0 0 8}$ & $\mathbf{2 0 0 9}$ & $\mathbf{2 0 1 0}$ & $\mathbf{2 0 1 1}$ & $\mathbf{2 0 1 2}$ & $\mathbf{2 0 1 3}$ & $\mathbf{2 0 1 4}$ \\
\hline US & 20732 & 20802 & 20687 & 20680 & 19490 & 18771 & 19180 & 18882 & 18490 & 18961 & 19035 \\
\hline Total & 83107 & 84411 & 85328 & 86741 & 86115 & 85066 & 87867 & 88974 & 89846 & 91243 & 92086 \\
\hline Share of Total & $24 \%$ & $24 \%$ & $24 \%$ & $23 \%$ & $22 \%$ & $22 \%$ & $21 \%$ & $21 \%$ & $20 \%$ & $20 \%$ & $20 \%$ \\
\hline
\end{tabular}

Table 14: US Oil Consumption

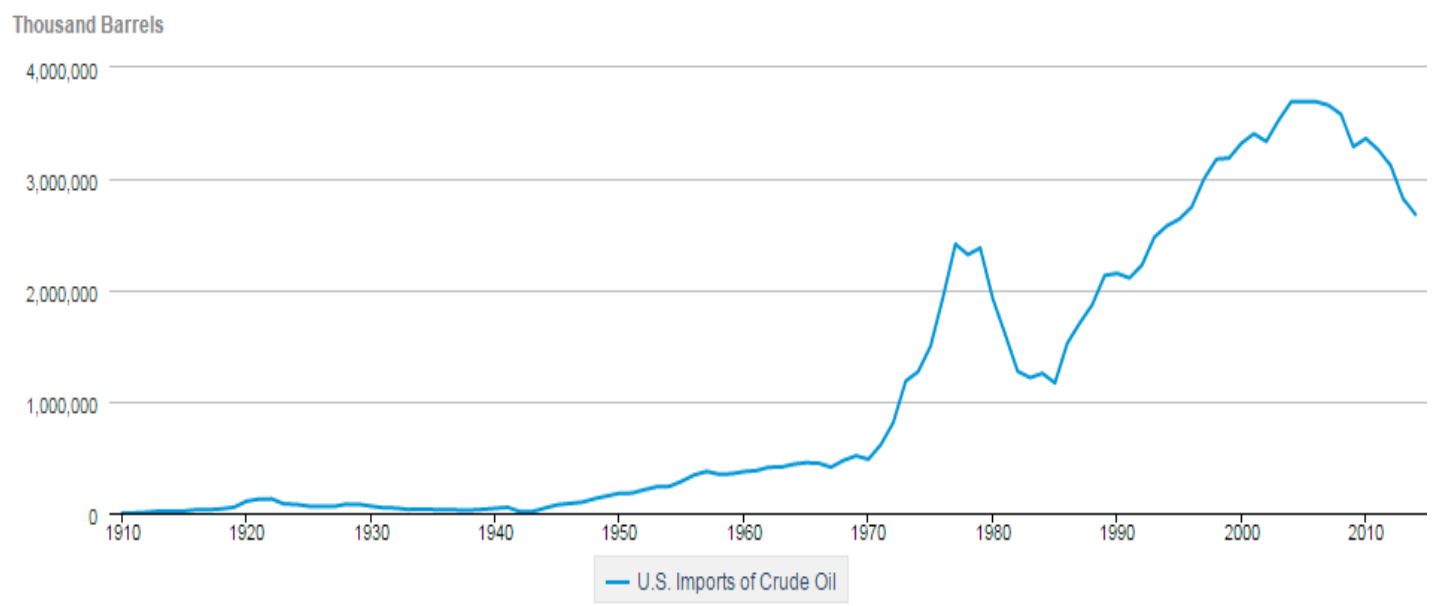

Chart 5: US Imports of Crude Oil

Sources: Based on the data available here:

http://www.bp.com/content/dam/bp/pdf/energy- economics/statistical-review-2015/bpstatistical-review-of-world-energy-2015-oil-section.pdf

, http://www.eia.gov/dnav/pet/hist/LeafHandler.ashx?n=pet\&s=mcrimus $1 \& \mathrm{f}=\mathrm{a}$ 
According to Chart 5, from the 1970s, the United States has aggressively and consistently increased its crude oil imports. This corresponds to the beginning of the structural shift towards neo-liberalization and radical technological developments pertaining to energy. In turn, new and strong economic ties between the GCC states/elites and TCC emerged. For the TCC, these ties meant the stability of GCC states would remain crucial for TCC's economic activities and global capital accumulation.

\section{Militarization and Conflicts among Classes in the Persian Gulf}

The position of GCC royal families has been occasionally, but notably, challenged from time to time. In each of these episodes, the possible or actual threats to GCC royal families has led to further militarization of the Persian Gulf. Arguably one of the most important of these events was the Iranian Revolution. The regime change in Iran was an alarming sign for the GCC royal families. While the eye of the world focused, for the most part, on the domestic implications of the changes in Iran, the GCC royal families anxiously monitored any potential domino effect on other Middle Eastern societies, especially due to the radical rhetoric of the revolutionary leaders that invited all Muslims to challenge the pro-Western political regimes all over the Muslim world.

From the beginning of the 1980s, efforts to weaken the Saudi royal family have been part of an important, albeit not always dominant, discourse in Iranian foreign policy. It is worth mentioning that what happened in Iran in 1979 did not result in an anti-capitalist system. The new class arrangement in Iran indicates a new model of indigenous capitalism, which curiously enough is not connected to Western capitalism in any significant way aside, of course, from the need for access to an international financial structure. Within this small capitalist microcosm, there is a class-based tension between the ruling elites in Iran 
and in Saudi royal family. This is the reason why Saudi foreign policy mirrors that of Iran, in that Saudi Arabia embarked on an aggressive effort to isolate and weaken the postRevolution Iranian regime as soon as that regime was born.

The Saudi royal family viewed the new regime in Tehran as an existential threat for their ruling status at home. Some of the disadvantaged and excluded minorities in the GCC, and especially those of Shi'i persuasion, found comfort and inspiration in Iran's post-Revolution rhetoric, and perceived or actual ties between them and Tehran became a new challenge in states/elites' relations in the GCC. Generally speaking, the stability of the GCC transnational space required a highly militarized state (elites) relationship. According to Doug Stokes and Sam Raphael, "the militarization of the oil-rich South ranges far wider than state infrastructure protection. Indeed, security assistance is geared more around active counterinsurgency. Training and equipment programs are designed to build local capabilities for rapid reaction, troop mobility, intelligence networks, night-fighting, surveillance, and offensive tactics" (Stokes and Raphael, 2010, P. 78).

Added to this growing conflict between Riyadh and Tehran, the fact that, after the Iranian Revolution, the United States lost its key, strategic ally in the region created a strategic vacuum that the Saudis conveniently filled. Iran used to be the surrogate proxy that protected the U.S. interests in the region - or at least it was perceived as such according to the so-called Nixon Doctrine. After the Revolution, however, the "Carter Doctrine" was added to the mix, as the Carter Administration decided to send the U.S. military directly to the Persian Gulf to contain Iran's Revolution. By default, Saudi Arabia became the new surrogate proxy - or at least it was perceived as such. This ushered in a new era where the militarization of the Persian Gulf was not just through competition among 
surrogate powers, but also through the direct U.S. military presence in the region with consequences far beyond what the United States had anticipated.

Later events solidified the key tenants of the Carter Doctrine, especially in light of the Gulf War and the 9/11 terrorist attack. This shift could not have happened without the support of the GCC rulers. In the post-9/11 world, the GCC increased its military expenditure in response to increased securitization of the Muslim World. According to William Robinson, "in the post-9/11 period the military dimension appeared to exercise an over-determining influence in the reconfiguration of global politics. Militarization has involved not just the major U.S.-led interventions but the adoption by 144 countries of "counterterrorist" laws and the development of enhanced systems of policing, internal security, urban militarization, and social control to suppress dissent (and also to make profits)" (Robinson, 2014, pp. 150-151). Therefore, before further discussion of militarization of the Persian Gulf, it is necessary to have a brief discussion of how the notions of "counter-terrorism" and "counter-insurgency" have been translated in GCC states' political discourse.

\section{Counterterrorism and Counterinsurgency: US Military Arms Sales, and GCC}

\section{State Repression}

A conceptual starting point in analyzing "counterterrorism" is the Neo-Gramscian understanding of the notion of hegemony. The third world militarization is part of a broader structure in which a global hegemony is being established and reinforced based on dynamics of consent and coercion. With respect to the hegemonic power of the GCC capitalist class in their respective societies, some evidence suggests that the GCC bourgeoisie class has had considerable difficulty bringing in the consent element to 
their hegemonic mold. This is partly due to the ongoing, and at times direct, use of military and security powers to control other social classes. Arguably, Saudi Arabia and other GCC states have never been able to fully implement a genuine "counter-terrorism" policy for both structural and tactical reasons. According to the United States Department of Defense, "[t]errorism is often motivated by religious, political, or other ideological beliefs and committed in the pursuit of goals that are usually political" ${ }^{30}$ (Joint Publication 3-07.2 on "Antiterrorism", 2010, P. vii).

If we accept this definition as a working definition (while acknowledging all the difficulties that arise when one is to define the loaded term "terrorism), we will be able to identify some of the key problems a Saudi counterterrorism policy would encounter. One crucial fact, of course, is that Saudi Arabia has invested significantly and for a long period in propagating an ideology that, accurately or inaccurately, is viewed as lending support to the radical groups. This ideology, often called Wahhabism, is the founding ideology of the Saudi Arabia and its royal family; but it is in the past few decades the ideology that has been aggressively exported throughout the Muslim World. This expansion now goes far beyond pure ideological propagation and involves complex economic and financial manifestations. The economic ties are not always clear or straightforward indeed. For instance, Rotana Group, which reportedly controls "around $45 \%$ of all the movie industry and around $75 \%$ of all the music" in the Middle East (Zendrian, 2010, Forbes), is owned by Al-Waleed Bin Talal, a Saudi prince who is

\footnotetext{
${ }^{30} \mathrm{http} / / /$ www.dtic.mil/doctrine/docnet/courses/operations/icdjo/resources/JP3_07X2.pdf
} 
considered pro-West, but nonetheless belongs to a royal family whose very legitimacy comes from an anti-West ideology. Interestingly, 18.97 percent of the same Rotana Group's stocks are owned by the News Corp.

The ironies of the interaction between Wahhabism and the West are even more evident in the geopolitical landscape of the region. Saudi Arabia remains, for the time being, one of the significant U.S. allies in the Middle East, while Wahhabism is almost universally acknowledged as one of the founding ideologies of Al-Qaeda and, more recently, ISIS. On the one hand, the Saudis, many of whom sympathize if not adhere to the Wahhabi ideology, are engaged in economic and military businesses with the Western countries, and they also make charitable donations to the American educational system (see the complementary argument at the end of this chapter). On the other hand, offshoots of Saudi Wahabbism in the form of Al-Qaeda and ISIS espouse a strong anti-American position and reject Westernization and modernization altogether. At the same time, there is ideological support for the radical Wahabis by such important Saudi Sheikhs as Mohamed Al-Arifi (The Muslim Issue, 2014). Indeed, one would presume that a starting point for counter-terrorism would be removing the very ideology of extremism from education system. In a stark contrast, GCC states continue to invest in expansion of Wahhabism into other countries. For instance, a cable released by WikiLeaks tells us:

"During recent [2008 November 13] trips to southern Punjab, Principal Officer was repeatedly told that a sophisticated jihadi recruitment network had been developed in the Multan, Bahawalpur, and Dera Ghazi Khan Divisions. . . Government and non- governmental sources claimed that financial support estimated at nearly 100 million USD annually was making its way to Deobandi 
and Ahl-e-Hadith clerics in the region from "missionary" and "Islamic charitable" organizations in Saudi Arabia and the United Arab Emirates ostensibly with the direct support of those governments". ${ }^{31}$

Saudi Arabia has also funded Wahhabi schools in Indonesia, the Philippines, Malaysia, Thailand, India and parts of Africa. Most of these schools are located in the poor areas where the only option for people to receive an education is in such schools ${ }^{32}$. The question remains how GCC states could effectively challenge the foundational ideology of terrorism while at the same time continuing to invest in the same ideology. According to a CRS Report for Congress:

"It is widely acknowledged that the Saudi government, as well as wealthy Saudi individuals, have supported the spread of the Wahhabist ideas in several Muslim countries and in the United States and Europe. Some have argued that this proselytizing has promoted terrorism and has spawned Islamic militancy throughout the world. Saudi funding of mosques, madrasas, and charities, some of which have been linked to terrorist groups such as Al Qaeda, has raised concern that Wahhabi Islam has been used by militants who tailor this ideology to suit their political goals and who rely on Saudi donations to support their aspirations". ${ }^{33}$ (Blanchard, CRS 4, [Footnotes Omitted])

\footnotetext{
${ }^{31} \mathrm{https} / / /$ www.wikileaks.org/plusd/cables/08LAHORE302_a.html

${ }^{32} \mathrm{http}: / /$ www.huffingtonpost.com/dr-yousaf-butt-/saudi-wahhabism-islamterrorism_b_6501916.html

${ }^{33}$ Blanchard, C. M. (2007, January). The Islamic Traditions of Wahhabism and Salafiyya. LIBRARY OF CONGRESS WASHINGTON DC CONGRESSIONAL RESEARCH SERVICE./ http://fpc.state.gov/documents/organization/101756.pdf
} 
Meanwhile, there are some indications that the vast military and security investments of GCC states primarily target certain groups and ideologies that may challenge the position of the GCC's ruling families. In other words, counterterrorism and counterinsurgency policies within the GCC is better understood by locating these policies within the domestic class structure of accumulation of capital that the GCC depends on for its regional share of global corporate profits. Counterterrorism and counterinsurgency policies have provided more "opportunities" for the GCC to pursue its own regional class projects, often with supplementary funding injected by the TCC via Western states. Accordingly, the counterterrorism policies of the GCC are developed, constrained and informed by the links to the ruling elites of the GCC, who use counterterrorism as a set of tools to perpetuate their economic and political interests and power. This also means contradictions with the counterterrorism policy, illustrated by the dependence of the GCC on Wahabbism in maintaining stability.

In addition, the policy of counterinsurgency is based on the interests of the GCC capitalist class. According to one U.S. government counterinsurgency guide, "[c]ounterinsurgency (COIN) is the blend of comprehensive civilian and military efforts designed to simultaneously contain insurgency and address its root causes. Unlike conventional warfare, non-military means are often the most effective elements, with military forces playing an enabling role. COIN is an extremely complex undertaking, which demands of policy makers a detailed understanding of their own specialist field, but also a broad knowledge of a wide variety of related disciplines" 34 (2009, P. 2).

\footnotetext{
${ }^{34}$ http://www.state.gov/documents/organization/119629.pdf
} 
If we use this definition as a working definition, while acknowledging the many caveats that accompany that definition, we can recognize many contradictions and ironies in U.S. and GCC counterinsurgency strategies in the Middle East. The U.S. counterinsurgency strategy in the Middle East, for instance, manifests a neglect of many security threats. One painful outcome was the complete blindness of Western intelligence elites to the upcoming Iranian Revolution in 1979. Before the Iranian Revolution, Iranian security forces and the so called SAVAK (Organization of Intelligence and National Security) were supposedly a part of the U.S. counterinsurgency strategy in the region, as they were fighting against a wide range of leftist and nationalist movements in Iran. Part of their strategy was to empower Islamist groups who were ideologically against communism to balance the threat of a communist revolution in Iran. The result was an Islamic Revolution that went under the radar of nearly every Western intelligence service.

A similar strategy seems to have been pursued in the GCC states. The GCC counterinsurgency strategy focuses on repressing any local voice that can create a nationally- oriented political economy. In other words, a nationalization of GCC political economy would be viewed structurally opposed to the current GCC transnational space. Therefore, counterinsurgency has appeared as a tool to maintain the status quo in which the Western MNCs have safe and secure access to oil and other transnational practices in the region. The following map is an illustration of the concentration of militarization around Persian Gulf oil fields. 


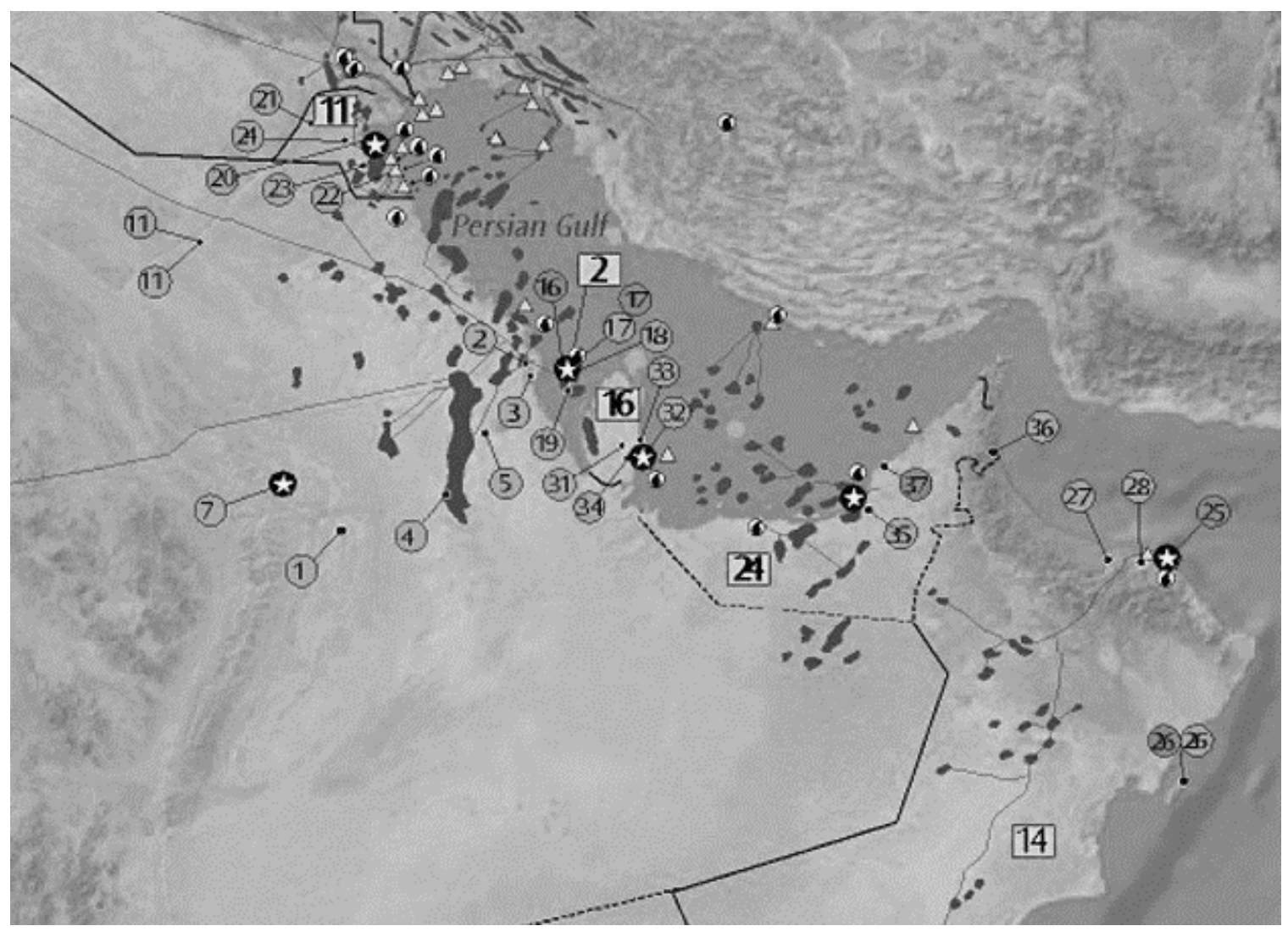

Map 1: U.S military presence in the Persian Gulf region and some of the nearest oil fields Source: http://www.theglobaleducationproject.org/mideast/info/maps/middle-eastmilitary-and- oil-map.jpg

The above map shows the United States military facilities by circles that represent U.S. Air Force bases, U.S. Navy bases, U.S. Army bases. To help better understand the geostrategic significance of the U.S. military presence in the region, the map also shows oil and gas resources with brown stains representing oil fields, and the blue ones representing natural gas fields. The close proximity of U.S. military bases to the oil and gas fields is no coincidence; and the fact that those fields are usually close to water makes the placement of military bases in their vicinity more convenient, as access to the high seas would basically create a suitable strategic location for a military base. 
In the case of the GCC, the security vacuum created by the U.S. counterinsurgency strategy and its impact on counterterrorism produced a blend of corporate capitalism and counterinsurgency: "multinational corporations usually become involved in counterinsurgency when their corporate interests (financial interests, foreign based personnel, or infrastructure, etc.) are threatened, or when a financial advantage is perceived. COIN planners will not always have the ability to influence the activities of multi-national corporations in an affected country, but may find that their interests complement the COIN effort. In particular, firms in extractive sectors (oil, mining, etc.) have large initial investment and long production cycles, which mean that withdrawal from a country could result in significant financial cost. For such companies, investment in local stabilization activities (from micro-loans to security sector reform activities) makes economic sense"35 (2009, P. 34).

Connecting the long-term national counterinsurgency strategy of the most powerful military in the world with divergent and often shorter-term interests of multinational corporations in dealing with one of the most chaotic regions of the world has obviously had far reaching consequences, including, but not limited to, the collapse of Libya, Syria and Yemen and the dysfunctional state of the government of Iraq and arguably that of Egypt today. However, the current counterinsurgency strategies that protect the GCC royal families and TCC interests in the region are not simply a means to an end; the counterstrategy itself is emerging as an industry - an end in and of itself, and therefore,

\footnotetext{
${ }^{35} \mathrm{http}: / /$ www.state.gov/documents/organization/119629.pdf
} 
yet another economic tie between the GCC and TCC. For instance, Vindell, which is a private military corporation based in the U.S., has been in the business of training Saudi Arabian National Guard (SANG) for decades now:

“In February 1975 Vinnell secured a US\$77 million contract with King Fahd to train the Saudi Arabian National Guard (SANG), the military arm of the House of al- Saud. Today, Vinnell's advertising depicts the firm as 'providing a broad spectrum of professional and technical services to government clients in multiple areas of management and training. Client requirements have led Vinnell to a vast array of challenges, from Malaysia to Mexico to the Middle East, often to the very heart of international conflict areas. Vinnell has subsidiary operations in Egypt, Oman, and Turkey, but the key area of responsibility remains with SANG. The contract for its one thousand-plus-strong team of advisors was extended in January 1994 to the year 2000 at a cost of US $\$ 819$ million." ${ }^{36}$

\section{GCC State Repression and Working Class}

The reason for employing military forces internally is arguably to guard against security threats to GCC elites' interests, including their property interests. In other words, there is an inherent linkage between the militarization of the GCC states, on the one hand, and GCC's "controlling" and "repressing" the region's working class, on the other. The repressive sociopolitical structures of the GCC find their parallels in there structuring of

\footnotetext{
${ }^{36}$ Sheppard, S. (1998). Foot soldiers of the new world order: the rise of the corporate military. New Left Review, (228), 128.http://newleftreview.org/I/228/simon-sheppard-foot-soldiers-of-thenew-world-order- the-rise-of-the-corporate-military
} 
the transnational working class in the GCC. GCC elites have successfully restructured the working class transnationally at the same time as these elites were expanding their transnational class interests. In other words, the repressive political architecture benefits both GCC regional interests and GCC/TCC transnational interests.

Prior to the emergence of the current transnational labor class, GCC states used to witness frequent demonstrations within their societies, particularly instigated by violation of labor rights. Just a few decades ago, a considerable percentage of the GCC working class consisted of Arab laborers from other Arab states. Based on the Arab background of most foreign laborers, it was difficult for the GCC elites to suppress them, on the one hand, or to gain hegemonic power in the Arab World, on the other. The demography of the GCC labor class has now changed, however, and a transnational labor class has been created in which Arab laborers are but a small part-see the Table 15.

\begin{tabular}{|l|c|c|c|c|}
\hline & 1975 & 1985 & 1996 & $\mathbf{2 0 0 2 / 4}$ \\
\hline Bahrain & 22 & 15 & 12 & 15 \\
\hline Kuwait & 80 & 69 & $33^{* *}$ & $30^{* *}$ \\
\hline Oman & 16 & 16 & 11 & 6 \\
\hline Qatar & 33 & 33 & 21 & 33 \\
\hline Saudi Arabia & 91 & 79 & 30 & 13 \\
\hline UAE & 72 & 19 & 31 & 32 \\
\hline GCC & & 56 & & 10 \\
\hline
\end{tabular}

Table 15: Arab Share of Foreign Population in GCC

Source: Borrowed from here; http://www.un.org/esa/population/meetings/EGM_Ittmig_Arab/P02_Kapiszewski.pdf, P. 
By reducing the use of foreign Arab laborers to diminish the pressure from the rest of the Arab world, the militarization of GCC labor policy created a transnational working class in the region that is largely unprotected. This was a welcome development for GCC elites: the non-Arab foreign labors spared GCC states from having to repress Arab people and allowing them to claim hegemonic power over the Arab World while, at the same time the working conditions in their countries worsened. From the 1970s and 80s, the GCC actively started to create a transnational labor class by opening its local labor markets to global labor supplies. This shift is crucial for the purpose of understanding the emergence of a transnational GCC capitalist class, which depended on restructuring of the workforce to facilitate production and was backed up by aggressive militarization, which amounted primarily to internal security measures against the working class.

Parallel to this policy, GCC states started to give generous social welfare to their own nationals while marginalizing them from important economic activities. Therefore, the violation of human rights and labor rights became irrelevant - or less visible - since these states claim that the laborers who migrated to GCC states have freely chosen to accept the difficult working conditions.

Today, the GCC elites/states are using a sophisticated combination of ideology, military power, and transnational globalization to maintain their suppressive status quo. Based on the data, some of which discussed in this chapter, the GCC transnational labor class is a key target of GCC's repressive structure. According to Human Rights Watch:

“... [p]olice and labor authorities [of the GCC] in 2014 continued a vigorous campaign to arrest and deport foreign workers found in violation of existing labor laws, targeting workers who did not have valid residency or work permits, or 
those found working for an employer other than his or her legal sponsor. According to the International Organization on Migration (IOM), Saudi Arabia deported 163,018 Ethiopians between November 2013 and March 2014, and 458,911 Yemenis between June 2013 and June 2014. There were reports that prior to deportation some deportees were placed in overcrowded detention conditions, denied adequate food and water, and physically abused by guards. Between December and March 2014, Saudi Arabia deported 38,164 Somalis to Mogadishu, including hundreds of women and children, without allowing any to make refugee claims. Domestic workers, most of them women, frequently endure a range of abuses including overwork, forced confinement, non-payment of wages, food deprivation, and psychological, physical and sexual abuse without the authorities holding their employers to account. Workers who attempted to report employer abuses sometimes faced prosecution based on counterclaims of theft or "sorcery." "37

\section{Capital Accumulation via Arms Deals}

The security shield for GCC transnational capital accumulation has linked to another capitalist structure, the military industrial complex. The sale of weapons, which protect the structure of the capital accumulation, is, in itself, a Western-based structure of accumulation of capital, showing a rather unusual case of harmony among different capitalist trends. For instance, Adnan Khashoggi, a wealthy Saudi businessman and a generous donor to American universities, has been alleged to be a Saudi arms dealer. Mr.

${ }^{37}$ https://www.hrw.org/world-report/2015/country-chapters/saudi-arabia 
Kashoggi appears to have close ties with the Saudi royal family, as his father was the personal physician to King Abdul Aziz Al-Saud. The allegations of arms dealing against him are long-standing. In January 1987, for instance, Time magazine referred to him as a "shadowy arms trader." The allegations go further to include old connections with the bin Laden family. Peter Bergen writes "[during the 1950s] Mohammed bin Laden [the father of Osama bin Laden] would [jump-start] the career of another Saudi billionaire, Adnan Khashoggi, known in the West for his flamboyant spending, his walk-on part in the Iran-contra scandal, and his nephew Dodi Fayed, who died along with Princess Diana in the Paris car crash. In the early 1950s, Mohammed needed some trucks for his construction business in a hurry. Khoshoggi was able to make a $\$ 500,000$ purchase of trucks in the United States, for which Mohammed paid him a commission of $\$ 50,000$. It was Khashoggi's first business deal" (Bergen, 2002, P. 47). Khashoggi has also been linked to other controversial cases such as money-laundering activities at India ${ }^{38}$ and even terrorism $^{39}$.

The GCC elites continue to play an important role in the global arms industry. This role has been possible thanks to petrodollars. The GCC's indigenous arms industries remain weak as the thrust of military expansion in the GCC continues to be the importation of advanced military weaponry and equipment while relying on foreign support and

\footnotetext{
${ }^{38}$ http://indianexpress.com/tag/adnan-khashoggi/

${ }^{39} \mathrm{http}: / /$ www.slate.com/articles/news_and_politics/chatterbox/2001/11/six_degrees_of_adnan_kh ashoggi_

part_4.html
} 
training. Military facilities that are mostly exported from the West to the GCC primarily function as a security assurance for the status quo forces within the GCC. The basic economic model can be described as using arms deals to recycle petrodollars. Therefore, it would be oversimplification to view these arms deals merely as a result of security concerns. Rather, in the process of decision making behind these deals lie important personal and power group interests. For instance, the $B B C$ reported in 2007 that "[t]he UK's biggest arms dealer, BAE Systems, paid hundreds of millions of pounds to the exSaudi ambassador to the US, Prince Bandar bin Sultan" 40 while then-Prime Minister Tony Blair prevented the investigation using a simple business logic: "I don't believe the investigation incidentally would have led anywhere, except to the complete wreckage of a vital strategic relationship for our country."41

\section{Military and Security Power as Tools of Maintaining the Hierarchy of Power in the Arab World}

One way to capture the class-based nature of the GCC's military power is to analyze the causes and implications of GCC policies and strategies on a wider regional level across the Middle East and North Africa (MENA). Historically, Saudi Arabia has aspired to become a leader in the MENA region. The modern history of MENA, on the other hand, consists of constant, and at times chaotic, changes, including the 1979 Iranian Revolution, the Iran-Iraq war, two Persian Gulf Wars, the Arab Spring and the collapse

\footnotetext{
${ }^{40}$ http://news.bbc.co.uk/2/hi/business/6728773.stm

${ }^{41}$ http://www.nytimes.com/2007/06/08/world/europe/08britain.html?pagewanted=print\&_r=0
} 
of Syria, Libya, Yemen and the rise of ISIS. This constantly changing and highly unpredictable environment has made it quite difficult for Saudi Arabia to design a coherent strategy that would secure its position as a regional superpower. Take the example of the Arab Spring. During the Arab Spring, there manifested a series of tensions among different ideologies in the Arab World, including the tension between secular and pre-secular worldviews, as well as tensions between socialism and capitalism.

Despite these tensions, the social movements in the Arab World found it possible, if only for a short but consequential period of time, to rally around some common causes and challenge the ruling classes in their respective countries. In other words, the Arab Spring arose from a deep collective desire to change the status quo and to create a new class arrangement in parts of the Arab World. This desire and its result, the toppling of one status quo regime after another, put Saudi Arabia, as a self-proclaimed leader of the Arab world, in an extremely uncomfortable position. The main tenets of the Arab Spring as a sociopolitical movement posed an existential threat for the economic and political positions of the GCC elites/states.

One of the strategic concerns of the GCC elites has been the fear of a decentralization or transformation of the current hierarchy of power via any new class arrangement in the Arab World. This strategic concern manifested itself in direct and indirect interventions of the GCC states to contain the Arab Spring in order to hinder any radical changes in the class arrangement of the Arab World. The approach was not quite different from the containment strategies the GCC states adopted in response to the Iranian Revolution some three decades ago. 
Following the collapse of President Mubarak and unsuccessful external efforts-from GCC and the United States to prevent a radical change in Egypt, the TCC seemed to favor Mohamed El-Beradei, the former Director General of the International Atomic Energy Agency (IAEA), as the new leader of "democratic" Egypt, due to his international statute and networks. El-Beradei was arguably the only leading figure who could transform Egyptian political structure into a polyarchic system acceptable to the TCC. The GCC states, however, had a different vision. It was in the strategic interest of the GCC to first derail the Egyptian anti-status quo revolution, dismantle the social construct that led to the revolution that consisted of mainly of leftists and nationalists, and finally restore a soft form of military dictatorship that would be a reliable ruling class that would support the interests of the current GCC elites/states and Arab capitalism. The GCC scored a significant victory in achieving all these goals, not through foreign intrusion but by channeling the Egyptian people's will to overthrow a democratically elected government and then voting in a military general. There is little doubt that the current military government could not have emerged without the support of Saudi Arabia, and without continued U.S. support of the Egyptian military. The Muslim Brotherhood, on the other hand, sowed the seeds for its fall from power by excluding and suppressing many social groups. The government under the Muslim Brotherhood started changing the institutional settings in favor of its own group interests (similar to indigenous capitalism that emerged in Iran after 1979 Islamic Revolution); but any such governing structure would have been a serious threat for TCC interests in Middle East, and importantly with respect to oil.

The Egyptian case indicates a possible new trend in the Middle East geopolitics in which GCC has now adopted: a neo-imperialist regional foreign policy to lead or support 
their regional strategies. Saudi Arabia had indeed the general support of the United States in the region. But more importantly, Saudis represented the essential interests of global TCC, and hence powerful economic and financial powers that supported the Saudis' strategy for containing the Egyptian revolution. According to a Congressional Research Service Report:

"Egypt's economy and national budget are slowly stabilizing, due in large part to the financial largesse of the Gulf Arab monarchies. Countries such as the United Arab Emirates, Kuwait, and Saudi Arabia have injected billions of dollars into the economy and treasury, providing cash grants, concessional loans, and fuel imports. Since the ouster of former president Morsi in July2013, Gulf states have provided government-to- government aid to Egypt possibly as high as \$30billion, 31 with billions more coming in the form of private sector investment. This assistance has bolstered the Sisi government and given it the confidence to enact some unpopular but fiscally prudent measures, such as reducing fuel subsidies by $30 \% . "{ }^{\prime 2}$ (Sharp, 2015, P. 8)

The economic support of the GCC - mainly by Saudi Arabia - was followed by the emergence of military-driven ties between GCC elites and the new dictatorship in Egypt. The military and economic aid by the United States to Egypt was about $\$ 1.5$ billion in 2013. ${ }^{43}$ Egyptian military leaders received the bulk of this aid. Recently, however, a

\footnotetext{
${ }^{42}$ https://www.fas.org/sgp/crs/mideast/RL33003.pdf

${ }^{43}$ http://www.nytimes.com/2013/08/20/world/middleeast/saudi-arabia-vows-to-back-egyptsrulers.html?_r=0
} 
shift, or at least a parallel development, may be seen. In his 2015 visit to Egypt, Saudi Defense Minister and Deputy Crown Prince Mohammed bin Salman negotiated with President Sisi for creation of a "joint Arab military force." ${ }^{44}$ In April 2015, according to the Egyptian Presidential office, "[i]t was agreed [between President Sisi and Prince Mohammed bin Salman] to form a joint military committee to discuss the implementation of a major strategic maneuver in the territory of the Kingdom of Saudi Arabia, with the participation of a joint Arab force which includes troops from Egypt, Saudi Arabia and the [Persian] Gulf states." 45

For our purpose, the example of the Bahraini social movement that was part of the Arab Spring is particularly relevant. Unlike many other Arab Spring countries, Bahrain is a GCC state. It is perhaps no overstatement that to Saudi Arabia, protecting the status quo in Bahrain was equivalent to protecting all the GCC states. While the Saudis reluctantly accepted President Obama's support for the fall of President Mubarak in Egypt, the Saudis conveyed their clear objection to any similar transition in Bahrain, forcing the U.S. to turn a blind eye on the fate of the Bahraini social movement. Albeit, in the case of Egypt, the U.S. was hoping to limit and contain these changes by preserving the Egyptian military as powerbroker while easing out Mubarak. As the Bahraini protestors were brutally suppressed by their government, Saudi troops were sent to protect the royal family of Bahrain. The U.S. criticized the ruling family of Bahrain while calling for restraint.

\footnotetext{
${ }^{44} \mathrm{http}: / / \mathrm{www}$.aljazeera.com/news/2015/07/saudi-arabia-egypt-sign-cairo-declaration150731005229377.html

${ }^{45}$ http://www.reuters.com/article/2015/04/14/us-yemen-security-egypt-saudiidUSKBN0N52CF20150414\#3qv5LCZvw3VBU1ox.97
} 
President Obama considered it sufficient to call for "respecting the universal rights of the people of Bahrain and reforms that meet the aspirations of all Bahrainis." The United States did not follow up on this call for protection of human rights in any serious manner. Similar to Egypt, this case also shows considerable cooperation and "give-and-take" between Western TCC states and the GCC states, rather than just conflicting policies between the two sides.

The GCC elites therefore, were successful in containing the anti-status quo forces in Egypt and Bahrain, the two countries with strategic significance to the GCC. Table 16 shows one index for "freedom" in Tunisia, Bahrain, and Egypt before, during, and after the Arab Spring, indicating the relatively successful transition of Tunisia to democracy, while in Bahrain and Egypt the status quo more or less survived the Arab Spring. In addition to the absence of strong labor unions and civil society institutions in Egypt and Bahrain, one key difference between these two and Tunisia was that Saudi Arabia did not have a strategic interest in maintaining the status quo in Tunisia, as it did in Egypt or Bahrain. 


\begin{tabular}{|c|c|c|c|c|c|c|c|c|c|c|c|}
\hline Egypt & Egypt & Egypt & Egypt & Bahrain & Bahrain & Bahrair & Bahrain & Tunisia & Tunisia & Tunisia & Tunisia \\
\hline Year & PR & CL & Status & Year & PR & CL & Status & Year & PR & CL & Status \\
\hline 2000 & 6 & & 5) NF & 2000 & 7 & & 6]NF & 2000 & 6 & & $\mathrm{NF}$ \\
\hline 2001 & 6 & & $6 \mid \mathrm{NF}$ & 2001 & 6 & & $5 \mid \mathrm{NF}$ & 2001 & 6 & & $\mathrm{NF}$ \\
\hline 2002 & 6 & & 6]NF & 2002 & 5 & & $5 \mid \mathrm{PF}$ & 2002 & 6 & & $\mathrm{NF}$ \\
\hline 2003 & 6 & & 6]NF & 2003 & 5 & & 5) $\mathrm{PF}$ & 2003 & 6 & & $\mathrm{NF}$ \\
\hline 2004 & 6 & & 5 NF & 2004 & 5 & & $5 \mid \mathrm{PF}$ & 2004 & 6 & & $\mathrm{NF}$ \\
\hline 2005 & 6 & & $5 \mathrm{NF}$ & 2005 & 5 & & $5 \mid \mathrm{PF}$ & 2005 & 6 & & $\mathrm{NF}$ \\
\hline 2006 & 6 & & 5 NF & 2006 & 5 & & $5 \mid \mathrm{PF}$ & 2006 & 6 & & $\mathrm{NF}$ \\
\hline 2007 & 6 & & 5 NF & 2007 & 5 & & $5 \mid \mathrm{PF}$ & 2007 & 7 & & $\mathrm{NF}$ \\
\hline 2008 & 6 & & 5 NF & 2008 & 5 & & $5 \mid \mathrm{PF}$ & 2008 & 7 & & $\mathrm{NF}$ \\
\hline 2009 & 6 & & 5 NF & 2009 & 6 & & $5 \mathrm{NF}$ & 2009 & 7 & & $\mathrm{NF}$ \\
\hline 2010 & 6 & & $5 \mathrm{NF}$ & 2010 & 6 & & $5 / \mathrm{NF}$ & 2010 & 7 & & $\mathrm{NF}$ \\
\hline 2011 & 6 & & \begin{tabular}{|l|l}
$5 F$ \\
\end{tabular} & 2011 & 6 & & 6 6F & 2011 & 3 & & $\mathrm{PF}$ \\
\hline 2012 & 5 & & $5 \mathrm{PF}$ & 2012 & 6 & & $6 \mathrm{NF}$ & 2012 & 3 & & $\mathrm{PF}$ \\
\hline 2013 & 6 & & $5 \mathrm{NF}$ & 2013 & 6 & & $6 \mathrm{NF}$ & 2013 & 3 & & $\mathrm{PF}$ \\
\hline 2014 & 6 & & 5) NF & 2014 & 7 & & 6) NF & 2014 & 1 & & $\mathrm{~F}$ \\
\hline
\end{tabular}

Table 16: Freedom Status in Egypt, Bahrain, and Tunisia Source: Freedom House

More importantly, the labor unions in Tunisia functioned as a structural obstacle against such external pressures as any potential GCC-backed intervention in two ways: ideologically and institutionally. In terms of ideology, Tunisian labor forces managed to mobilize the two competing trends within the Tunisian society, namely the secular and the Islamic trends. In many other Arab Spring countries, the tension between these two trends proved to be one of the main obstacles in the way of democratization, if not the main obstacle. With respect to institutions, Tunisian labor unions provided important indigenous institutional settings for sociopolitical activism, which in turn allowed the movement to go deeper than a mere street movement. In the case of Tunisia, the former dictator Ben 
Ali fled to Saudi Arabia where he was granted protection. That being said, GCC supported "Islamists that have gained power" (Colombo, 2012, P. 12).

Thus, GCC elites/states used their military and financial powers to protect the current socioeconomic class arrangement in the Arab World. In case of Bahrain, they used direct military power to suppress uprisings. In the case of Egypt, they empowered the Egyptian military to take over the state in order to stop any kind of meaningful democratization in Egypt at the expense of a weakened working class. In the case of Tunisia, they failed to penetrate into the dynamics of the uprising and the changes that were going on in the country because the Tunisian working class had sufficient institutional power to resist the interests of the GCC, at least temporarily.

With respect to the Arab Spring, each intervention may be better understood in terms of its importance to the GCC capitalist class. One important factor in analyzing the Arab Spring is that there has been tension and conflict between the GCC regional interests and TCC transnational interests. Similar to the period of nationalization, when the conflict between GCC and TCC resulted in a new arrangement, in the case of the collective responses to Arab Spring the consequential strategic interests are directly connected to the broader economic (class) interests of the GCC bloc, as well as this bloc's ties with the TCC.

\section{Conclusion}

A narrow segment of GCC society - royal families and merchant families - who controlled the upstream oil sector after nationalization began to establish economic ties with TCC business entities that were pushed to downstream sector (See Chapter 3). Within the current phase of transnationalization of the global economy, GCC elites/states 
are deeply connected to the TCC. This transnationalization and the ensuing segmentation imply a network of individual shareholders from different countries who control highly centralized modes of capital accumulation in the global oil market. Today, the primary goal of GCC militarization is protection of the GCC as an important part of this transnational globalization.

The GCC/TCC ties regarding militarization is primarily geared towards the interests of the GCC bourgeoisie in terms of the current mode of capital accumulation. As discussed in this chapter, the GCC class-based militarization is characterized by a series of challenges for the GCC bloc and TCC. One important reason for GCC militarization is the non-hegemonic nature of the GCC transnational space and the highly exploited transnational labor class in this region. A second reason is the external threats (mainly from Arab Spring) that challenge the current hierarchy of power in this region. Third is the new transnational ties via military deals that have empowered the GCC elites within TCC; this militarization endures as continuation of military business between members of TCC. A final reason can be found in the financial needs of Western military industrial complexes to petrodollars.

The militarization of the GCC is among the functional components of the current global mode of accumulation of capital. Structurally speaking, this militarization suppresses weaker social classes while the deals strengthen the economic ties between the GCC and TCC. The regional interventions of the GCC that manifest the same trend in that the GCC's regional concerns are based more and more on the fear of any changes in the hierarchy of power in the region affecting GCC/TCC corporate interests.

The GCC has internal domestic/regional interests and transnational interests that 
sometimes, though not always, overlap. The GCC bourgeoisie has appeared as the most reliable partner for the TCC in the Middle East. Securing the stability of the GCC, which is a structurally fragile region, is crucial for the TCC to secure its economic activities in that region. Despite the occasional tensions in cases such as nationalization and the Arab Spring, the outcome protects the interests of both the GCC and TCC. This overall harmony is the manifestation of the embeddedness of GCC elites/states within the TCC. 


\section{References:}

1. Bacevich, A. J. (2013). The new American militarism: How Americans are seduced by war. Oxford University Press.

2. Bergen, P. L. (2002). Holy war, inc.: Inside the secret world of Osama bin Laden. Simon and Schuster.

3. Blanchard, C. M. (2007, January). The Islamic Traditions of Wahhabism and Salafiyya. LIBRARY OF CONGRESS WASHINGTON DC CONGRESSIONAL RESEARCH SERVICE./http://fpc.state.gov/documents/organization/101756.pdf

4. Colombo, S. (2012). The GCC countries and the Arab Spring: Between outreach, patronage and repression.

5. Cox, Ronald. W. (2012). Corporate power and globalization in US foreign policy. London: Routledge.

6. Cox, Robert. W. (1996). Approaches to world order (No. 40). Cambridge University Press.

7. Cox, Robert. W. (1993). Gramsci, hegemony and international relations: an essay in method. Cambridge Studies in International Relations, 26, 49-49.

8. Dunne, P., \&Perlo-Freeman, S. (2003). The demand for military spending in developing countries. International Review of Applied Economics, 17(1), 23-48.

9. Hanieh, A. (2011). Capitalism and class in the Gulf Arab states. New York: Palgrave Macmillan.

10. Harvey, D. (2003). The new imperialism. Oxford University Press.

11. Hertog, S., Luciani, G., \& Valeri, M. (Eds.). (2013). Business politics in the Middle East. Hurst Publishers.

12. Kapiszewski, A. (2006). Arab versus Asian migrant workers in the GCC countries.

13. Klare, M. T. (1978). Militarism: The Issues Today1. Security Dialogue, 9(2), 121-128.

14. Payne, James L., 1989. Why Nations Arm. Oxford: Blackwell.

15. Potter, L. G. (Ed.). (2009). The Persian Gulf in History. Palgrave Macmillan.

16. Robinson, W. I. (1996). Promoting polyarchy: globalization, US intervention, and hegemony (Vol. 48). Cambridge University Press. 
17. Robinson, W. I. (2001). Social theory and globalization: The rise of a transnational state. Theory and Society, 30(2), 157-200.

18. Robinson, W. I. (2014). Global Capitalism and the Crisis of Humanity. Cambridge University Press.

19. Shrader, C. R. (2009). History of Operations Research in the United States Army. Office of the Deputy Under Secretary of the Army for Operations Research, US Army.

20. Smith, R. P. (1980). The demand for military expenditure. The Economic Journal, 811820.

21. Stokes, D., \& Raphael, S. (2010). Global energy security and American hegemony. JHU Press.

22. Tucker, S. C. (Ed.). (2014). Persian Gulf War Encyclopedia: A Political, Social, and Military History. ABC-CLIO.

23. Sheppard, S. (1998). Foot soldiers of the new world order: the rise of the corporate military. New Left Review, (228), 128.http://newleftreview.org/I/228/simon-sheppardfoot-soldiers-of-the-new-world-order-the-rise-of-the-corporate-military 


\section{Other Resources}

1. http://www.sipri.org

2. http://www.eia.gov

3. http://gmi.bicc.de/index.php?page=ranking-table\&year=2013\&sort=rank_asc

4. http://www.bloomberg.com

5. http://csis.org

6. https://www.mediaed.org

7. http://www.bp.com

8. http://www.dtic.mil

9. https://www.wikileaks.org

10. http://www.huffingtonpost.com

11. http://www.state.gov

12. http://www.theglobaleducationproject.org

13. http://www.un.org

14. https://www.hrw.org

15. http://indianexpress.com

16. http://www.slate.com

17. http://news.bbc.co.uk

18. http://www.nytimes.com

19. https://www.fas.org

20. http://www.aljazeera.com

21. http://www.reuters.com 


\section{CHAPTER V}

\section{CONCLUSION}

In each chapter of this dissertation I focused on certain aspects of the GCC that, while co- existing with each other, carried some degree of internal contradictions. The cumulative result of these contradictions is a series of tensions, which in turn leads to further contradictions. As David Harvey maintains, "[c]ontradictions have the nasty habit of not being resolved but merely moved around" (Harvey, 2013, P.4). This pattern of fluid contradictions and ebbs and flows of social tensions in essence summarizes the socioeconomic dynamics of the GCC countries in the past several decades and provides us with a sense of what to expect in the near future.

The nature of transnational elites, their relations, and their struggles within and without their groups are related to the essential characteristics of today's globalization. This dissertation has examined the extent to which GCC elites have been integrated into the TCC. It also discussed how this particular segment of the global structure of capital accumulation depends on a repressive state apparatus. Generally speaking, and in order to better understand the new patterns of global capitalism contextualized in the new socioeconomic arrangement of contemporary globalization, it is crucial to explore the critical, regional roles played by transnational elites.

The key contribution of this dissertation is to add to the expanding literature on the far-reaching consequences of transnational elites in various regions of the world by shedding some light on one of the important blocs of TCC's global structure. Various strands of argument here are primarily drawn from Neo-Gramscian schools of thought, in particular, Robinson 2003, Robinson and Harris 2000, and Sklair 2001. Accordingly, 
the core inquiry has been to understand the dominant forces within GCC capitalism as an extension of TCC's global capitalism that comes at the expense of states.

With respect to the field of Middle Eastern studies, the methodology used in this dissertation has been what is called the "process-tracing method." (See Chapter 1.) For reasons discussed earlier, this method allows us to better understand the embeddedness of the GCC elites within the TCC based on historical narratives and direct data. Importantly, this theory-oriented process-tracing method revealed no significant inconsistencies in the notion of GCC transnational elites between that of Neo- Gramscianism and the findings of this dissertation.

As discussed in the first chapter, this dissertation contributes an under-used mode of analysis based on Neo-Gramcianism to Middle Eastern studies which typically emphasizes understanding the institutional setting and arrangement of regime structure in Middle Eastern monarchies. These settings and arrangements include state building and the legacy of colonialism on various state institutions. (See, for instance; Fandy 1999, Herb 1999, Kechichian 2001, Kostiner 2000, Massad 2001, Tetrault 2000, Lucas 2004, Anderson 1986, Posusney \& Angrist 2005).

Another significant part of Middle Eastern studies literature focuses on the notion of rentierism. (See, for instance, Mahdavi, 1970 and Beblawi, 1987). However, the heterodox approaches, such as historical structuralism that was partly used in this dissertation are more or less based on classical class-based explanations (Hanieh 2011, Prashad 2002). Following these latter approaches, this dissertation recognizes the importance of class-based analysis; but it also applies it to a transnationally-oriented classbased context. In other words, this dissertation suggests that analyzing GCC transnational 
space and its actors should be the starting point for studying the political economy of GCC. The embeddedness of GCC elites within the TCC also explains the repressive state apparatus and the highly exploitive economic structure in which the GCC transnational working class lives.

According to Robinson, on the global level, the TCC is "[a] class group that has drawn in contingents from most countries around the world, North and South, and has attempted to position itself as a global ruling class. This TCC is the hegemonic fraction of capital on a world scale" (Robinson, 2014, P. 2). In order to avoid ambiguity with Robinson's theory, it is important to clarify how the terms elite and capitalist are employed in this analysis. Following Robinson, in this dissertation, in regards to the case study, I have used the terms elites and capitalist class interchangeably. According to Robinson:

"[B]y "elites" I mean dominant political, socioeconomic, and cultural strata and, in particular, capitalists and landlords, along with top-level managers and administrators of the state and other major social institutions and leadership positions in the political system. Capitalists are elites who own or manage means of production as capital. Elites who are not necessarily capitalists occupy key decision-making positions in institutions, whether in private corporations, the state, political parties, or culture industries". (Robinson, 2014, pp. 43-45)

As I described in chapters 2 and 3, GCC states have always been dominated by the ruling classes of the region. In the GCC the ruling and merchant families are by design capitalists; but they are also elites who are well-educated and well-positioned in the political system of GCC states. The core part of GCC capitalist class, including its elites, 
has been crystallized around family ties. In other words, in GCC the elites are necessarily members of a capitalist class. The nature of ownership and capital accumulation, such as activities conducted by these elites through SWFs and various GCC conglomerates have, along with their Westernized cultural education and life style rendered the GCC transnational elites "natural" members of the TCC.

\section{Development of Capitalism and the Crisis of Freedom}

As Robinson points out: "A 2011 analysis of the share ownerships of 43,000 transnational corporations undertaken by three systems theorists at the Swiss Federal Institute of Technology identified a core of 1,318 TNCs with interlocking ownerships. Each of these core TNCs had ties to two or more other companies, and on average they were connected to twenty. Although they represented only 20 percent of global operating revenues, these 1,318 TNCs appeared to own collectively through their shares the majority of the world's largest blue chip and manufacturing firms, representing a further 60 percent of global revenues - for a total of 80 percent of the world's revenue" (Robinson, 2014, P. 23).

Transnational globalization and the accompanying destruction of national and local economic entities have, under the banner of "increasing economic freedom," led to the rising power of oligarchs at the expense of weakening the working class. This dissertation analyzes the GCC transnational space and its repressive state apparatus. The repressive nature of politics that has emerged in the GCC is by no means limited only to GCC transnational space. Generally speaking, the new mode of capital accumulation that relies on transnational economic activities is based on an exploitive and inherently unbalanced hierarchy of power on a global level. This transnational mode of accumulation 
functions through economic and political ties that exist among various capitalist classes who, in turn, benefit from Western state institutions and a Western-oriented global hegemonic order. Meanwhile, the societies in the global South are excluded and controlled, in some cases, by economic statecraft and, in other cases, by brute military and security power. This economic oligarchy on the global level is an integral part of the structural power of TCC.

The highly exploitive nature of transnational activities requires, from time to time, the use of force by capitalist classes to control the exploited working classes and weaker states in the matrix of international relations. Force can be employed on different levels and can take different forms. On the global level, for instance, force may be used via an institutional setting against those states that are not willing to accept the new mode of capital accumulation. On a domestic level in the global South force is simply employed as naked authoritarianism. The rise of underlying authoritarian trends in the global South is nothing more than the reverse image of current transnational globalization. In many regions of the global South, such as Latin America or China, the structure of authoritarian power is far more sophisticated than the authoritarian trends we observe in the GCC.

On the global level the underlying rise of authoritarian trends is based on the use of force by economic statecraft and putting pressures on those states that are not willing to open up their economies to neo-liberal entities. The neo-Gramscian understanding of the notion of hegemony reveals that the global North countries maintain a certain level of mutual acceptance of the hierarchy of power. This acceptance extends to the interactions and tensions between Nordic model and neo-liberalism, and it results from the fact that use of military power is not the primary or strategic tool for the process of transnational 
globalization. On the other hand, the GCC has used its military and security powers as an indispensable tool of its capitalist strategy against both domestic and regional anti-status quo players.

While in periphery and semi-periphery countries the use of naked force may be more visible, in countries with advanced economic powers the so-called "Kremlin Bailout Technique" prevails. As Simon Johnson puts it, this technique is "[t]he assumption of private debt obligations by government" in which ordinary taxpayers repay the debt of corporations (Johnson, 2009) Economic recovery strategies in which governments bailout large financial institutions and multinational corporations at the expense of working and middle classes - often under the justification that they are "too big to fail" - are the familiar future of the deregulated financial world of today. These strategies, in their very essence, are nothing but oligarchic solutions for re-consolidation of neo-liberalism.

Another, somewhat similar authoritarian trend in advanced economies is what is sometimes called the Chinese development model. Through the engagement of foreign corporate powers, China has assumed a central position in the "global supply chain" facilitating further "transnational accumulation" (Cox, 2012, P. 31). At the same time, the emerging Chinese market clearly reveals the impacts of neoliberal globalization. In other words, China has used "authoritarian upgrading" in which an authoritarian regime has tried to consolidate its power through economic reform within the "context of contemporary globalization." (Cox-2012). The result has been the deteriorating situation of the labor class and rising inequalities that could eventually entail the use of force by the state, hence rendering the Chinese model of development unsustainable. 
The historical economic development of the GCC has conflated economic and social inequalities contextualized in the repressive presence of the state. To some extent, this situation is similar to the pattern of development in China. In contrast to China, however, the GCC transnationalization by and large ignores national infrastructures. While Chinese authoritarian development relies on foreign investment in manufacturing with a nationalistic theme, the GCC model has focused on transnational investments and its oil industry. Despite the differences, the GCC is struggling, like China, to position itself at the core part of the global supply chain.

\section{The GCC Model}

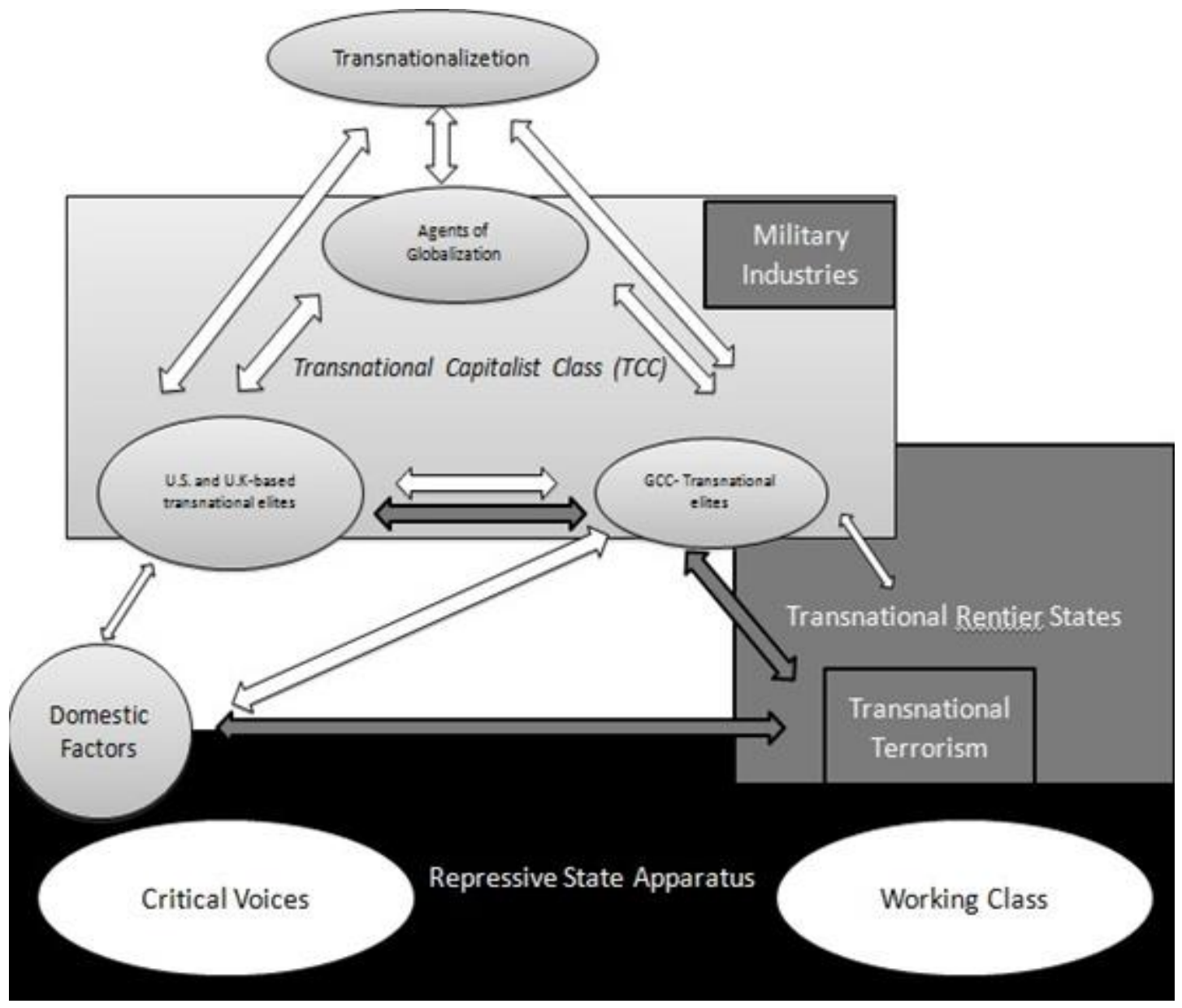

Figure 9: GCC Transnationalization 
The above figure shows the key analytical elements of this dissertation. The white arrows indicate a more or less aligned relationship while the gray arrows indicate some degree of tension between the elements. As discussed before, we believe that the embeddedness of GCC elites is an extension of a broader evolution of global capitalism. To oversimplify somewhat, this evolution, called the transnationalization of economic practices, serves as a new mode of capital accumulation. In this part of the model, the TCC, along with institutional agents of globalization (such as IMF) facilitated the growing positions of GCC elites within the global economy. However, in terms of domestic GCC politics there is a tension between TCC and GCC elites/states as the TCC's preference in this region is a polyarchy different from the Saudi version of oligarchical/nepotism model favored by the GCC elite. However, similar to the tensions between TCC and GCC elites that arose throughout the processes of nationalization, the new arrangement has not jeopardized the broader coalition of economic interests between the GCC and TCC. (See chapter 4.)

The second part of the above model depicts the connection between the GCC elites' embeddedness within TCC and certain domestic factors in the GCC. The predominant structure of transnational rentier states that exist in the GCC has provided a considerable level of welfare to the GCC rentier middle class. Ironically, however, the same structure has also resulted in alienation of the middle class, who have been excluded from of the process of decision making in their countries.

Furthermore, this paradoxical capitalist structure has also paved the way for antistatus-quo movements to gain currency. As the leftist and nationalist movements were aggressively suppressed under the banner of "fighting against anti-Islamic" groups, the 
only opposition groups that remained active have been the transnational terrorist organizations that follow the ideology of the Saudi royal family, namely Wahhabism.

This terrorist countermovement has two primary aspects. The first aspect is that the ideology of Wahhabismin has different shades that appeal to people excluded from the GCC mode of capital accumulation, as well as those who are members of the GCC bourgeoisie but nevertheless have ideological sympathies with Wahhabism. The aspect is that GCC capitalism uses the notion of "terrorism" to suppress almost any anti-status quo voices, ranging from Islamic leftists to religious and ethnic minorities. The global condemnation of terrorism provides a comfortable context for GCC elites to demonize any opposition by labeling it as terrorist. As a recent example, one may consider Saudi Arabia's execution of a Shia clergyman, Sheikh Nimr al-Namir, in 2016, which it justified as an act of counterterrorism. Although Sheikh Namir, a relatively marginal Shi'a leader in Saudi Arabia, was a staunch supporter of Iran's model of theocratic political system and an unequivocal opponent of the Saudi royal family, many observers raised doubt as to whether classifying him as a terrorist was appropriate. The irony becomes somewhat more visible when one considers that the underlying ideology of terrorism, Wahhabism, has from its very early days positioned itself in opposition to Shi'a Islam, which Wahhabi leaders continue to view as a heresy. M any reformers in Saudi Arabia have been arrested under the pretext of the "anti-terror law." According to a report by Amnesty International, "hundreds of people have been arrested for demonstrating, while the government has drafted an anti-terror law that would effectively criminalize dissent as a "terrorist 
crime" and further strip away rights from those accused of such offences. ${ }^{46}$ The skillful management of this second aspect of "terrorism" - the states' use and misuse of the concept - is one of the primary concerns of GCC states/elites. As discussed elsewhere, far from trying to contain the spread of more radical strands of Wahhabism, the GCC has been investing in "exporting" those extreme ideologies to the rest of the Muslim World, supposedly under the assumption that by exporting extreme ideas and people to other places, the ruling elites would have less to be worried about domestically. This explains the last part of the model that depicts the real targets of the GCC security and military powers: the working classes as well as a wide range of reformists voices.

While there are significant tensions and paradoxes between GCC societies and Western societies, GCC transnational elites have established their ties in Western societies through a sophisticated network of lobbyists as well as generous and strategic investments in Western academia. That being said, the culture of GCC transnational elites, which has been influenced by the culture of the TCC, is a Western-oriented culture in its roots. This is despite the fact that important sections of the GCC societies still follow a pre-secular, religious, and anti-Western traditions, some of which are espoused by Wahhabism. Again, this severe tension between the elites' worldview and that of the masses creates a fertile ground for the rise of violent extremism.

\footnotetext{
${ }^{46} \mathrm{https} / / / \mathrm{www}$.amnesty.org/en/latest/news/2012/01/reform-activists-saudi-arabia-must-receivefair- appeal-hearings/
} 
The transnationalization has also increased the authoritarian tendencies in global governance. On the one hand, the oppositions against this transnationalization has justified the current and steady increase in militarization. On the other hand, the evidence suggests that such militarization has failed to solve the root problem or even alleviate the current human catastrophes in the Middle East caused by terrorism and transnational crimes. More than a decade after 9/11 terrorist attacks, and after spending enormous amounts of resources on counterterrorism, the blight of terrorism has consistently and considerably increased in the region as the following chart shows.

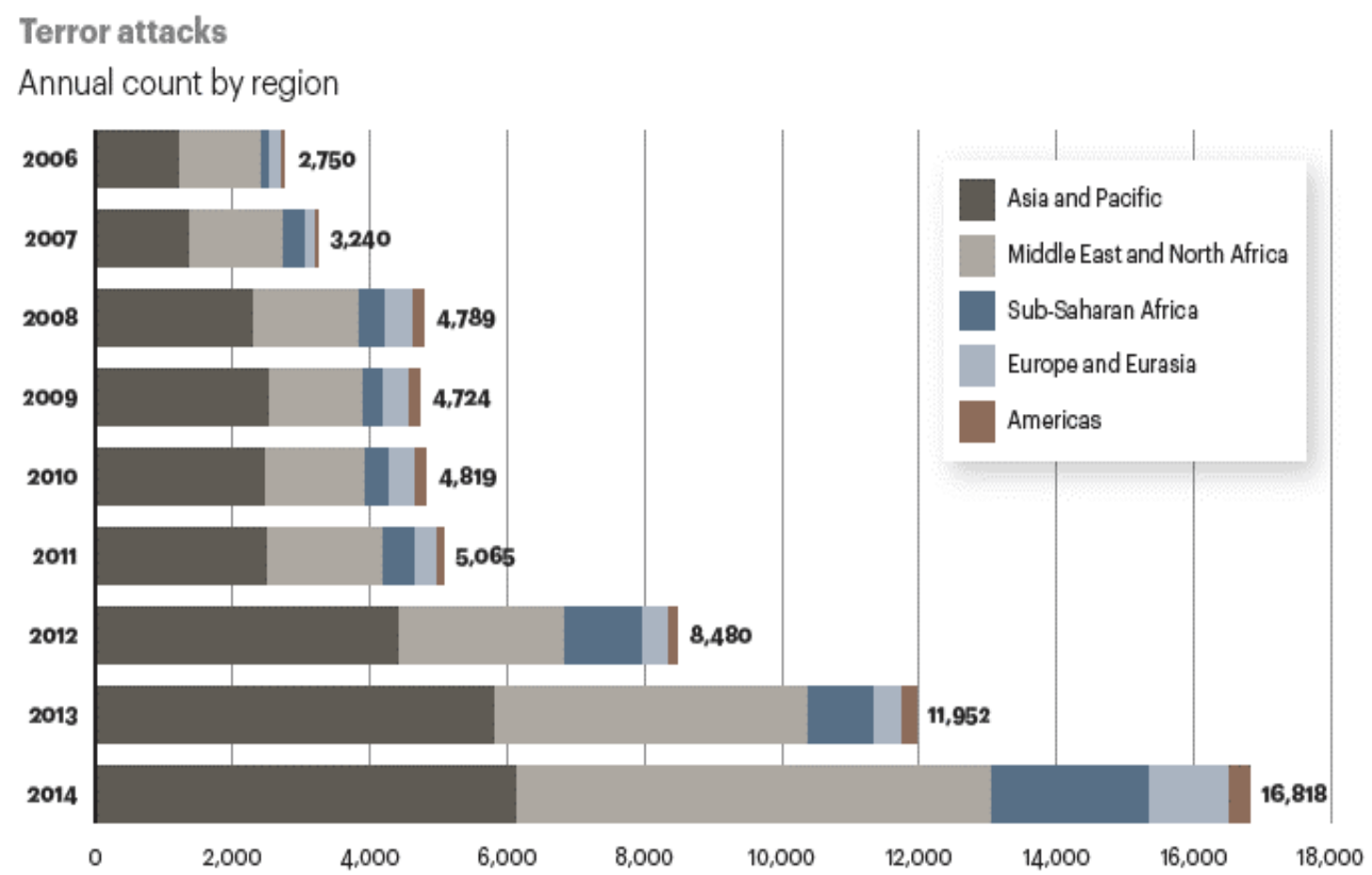

Sources: Global Terrorism Databse of the National Consortium for the Study of Terrorism and Responses to Terrorism (START); A.T. Kearney analysis

Chart 6: Terror Attack, Annual Count by Region

Source: Borrowed from;

Https: //www.atkearney.com/gbpc/detail//asset_publisher/0cePdOWatojD/content/globaltrends-2015-2025-divergence-disruption-and-innovation/10192 


\section{Final Note}

The embeddedness of GCC elites within TCC came with the decentralization of capital accumulation along with centralization of those who benefit from the current mode of capital accumulation, i.e. the TCC. The GCC offers an important case study for analyzing the structure and consequences of the current phase of globalization. It clearly shows the significant role of the TCC as a force in shaping the global economy. The TCC's impacts, however, may differ from one region to another. This dissertation is a humble contribution to the larger assessment of the role played by transnational elites in the GCC and of the regional and global consequences of their power struggles. The findings suggest that the transnational elites of the GCC, as one of the important nodes of global market economy, are members of the TCC, a group whose decisions have farreaching impacts on the regional and global economies. However, the current suppressive mode in the GCC is an outcome and an essential part of GCC transnationalization. This is partly due to the profitable military deals between members of the TCC, on the one hand, and the level of violence in the Middle East, on the other. The Middle East, as one of the most militarized regions in the world, is the only region where systemic violence has been simultaneously, and at points paradoxically, directed against modernization, Westernization, and globalization, because the GCC elites represent all three at the same time. 


\section{References:}

1. Anderson, L. (2000). Dynasts and nationalists: why monarchies survive. Middle East Monarchies. The Challenge of Modernity, Boulder: Lynne Rienner, 53-70.

2. Beblawi, H. (1987). The rentier state in the Arab world. Arab Studies Quarterly, 383398.

3. Cox, Ronald. W. (2012). Corporate power and globalization in US foreign policy. London: Routledge.

4. Cox, Robert. W. (1996). Approaches to world order (No. 40). Cambridge University Press.

5. Cox, Robert. W. (1993). Gramsci, hegemony and international relations: an essay in method. Cambridge Studies in International Relations, 26, 49-49.

6. Cox, Robert. W. (1981). Social forces, states and world orders: beyond international relations theory. Millennium: journal of international studies, 10(2), 126-155.

7. Fain, W. T. (2008). American ascendance and British retreat in the Persian Gulf region. Palgrave Macmillan.

8. Gause, F. G. (2011). Saudi Arabia in the New Middle East (No. 63). Council on Foreign Relations.

9. Gause, F. G. (2000). The persistence of monarchy in the Arabian peninsula: a comparative analysis. Middle East Monarchies: The Challenge of Modernity. Boulder: Lynne Rienner.

10. George, A. L., \& Bennett, A. (2005). Case studies and theory development in the social sciences. Mit Press.

11. Hall, P. A. (2003). Aligning ontology and methodology in comparative research. Comparative historical analysis in the social sciences, 374.

12. Hanieh, A. (2011). Finance, oil and the Arab uprisings: the global crisis and the Gulf States. Socialist Register, 48(48).

13. Hanieh, A. (2011). Capitalism and class in the Gulf Arab states. New York: Palgrave Macmillan.

14. Harvey, D. (2005). A brief history of neoliberalism. Oxford University Press.

15. Johnson, S. (2009). The quiet coup. The Atlantic, 1. https://www.amnesty.org/ 
16. Krämer, G. (2000). Good Counsel to the King: The Islamist Opposition in Saudi Arabia, Jordan, and Morocco. Middle East Monarchies-the Challenge of Modernity, Boulder: Lynne Rienner, 257-287.

17. Lucas, R. E. (2004). Monarchical authoritarianism: survival and political liberalization in a Middle Eastern regime type. International Journal of Middle East Studies, 36(01), 103-119.

18. Prashad, V. (2012). Arab Spring, Libyan Winter. AK Press.

19. Policy, F. (2012). FSI 2012, The Fund for Peace. the Fund for Peace.

20. Potter, L. G. (Ed.). (2009). The Persian Gulf in History. Palgrave Macmillan.

21. Robinson, W. I. (2003). Transnational conflicts: Central America, social change and globalization. Verso.

22. Robinson, W. I. (2005). Gramsci and Globalisation: From Nation-State to transnational Hegemony. Critical review of international social and political philosophy, 8(4), 559574.

23. Robinson, W. I. (2004). A theory of global capitalism: Production, class, and state in a transnational world. JHU Press.

24. Robinson, W. I. (2014). Global Capitalism and the Crisis of Humanity. Cambridge University Press. Chicago

25. Robinson, W. I., \& Harris, J. (2000). Towards a global ruling class? Globalization and the transnational capitalist class. Science \& Society, 11-54.

26. Sklair, Leslie (2001) The transnational capitalist class Wiley-Blackwell Publishing, Oxford, UK. ISBN 9780631224624

27. Soederberg, S. (2004). The politics of the new international financial architecture: Reimposing neoliberal domination in the global south. Zed Books.

28. Tilly, Charles. "Means and ends of comparison in macrosociology. "Comparative Social Research 16 (1997): 43-54.

29. Wade, R. (2006). Choking the south. New Left Review, 38, 115.

30. Wade, R. H. (2002). US hegemony and the World Bank: the fight over people and ideas. Review of international political economy, 9(2), 215-243. 
VITA

\section{SEYED AHMAD MIRTAHERI}

Born, Tehran, Iran

$2005-2010$

B.A., Economics

Allameh Tabatabaii University

Tehran, Iran

2011-2016

Doctoral Candidate

Florida International University

Miami, Florida

Teaching Assistant

Florida International University

Miami, Florida

FIU Middle East and Central Asian Studies Certificate

Florida International University

Miami, Florida

\section{PUBLICATIONS AND PRESENTATIONS}

Mirtaheri S.A. (November 2012) The Root Causes of Revolutions in Oil-based Budget Semi-periphery Countries: The Case of the Iranian Islamic Revolution, Paper presented at the First Annual PIR Graduate Student Conference , Florida International University, Miami.

Mirtaheri S.A. (March 2013) Economic Sanctions and the De-facto State of War Paper presented at FPSA, Florida International University, Miami.

Mirtaheri S.A. (April 2013) The Hybrid Theoretical Approach to Understanding Economic Sanctions Paper presented at MPSA, Chicago

Mirtaheri S.A., (August 2013) The Politics of Ahmadinejad and Chavez: A Misplaced Comparison, Class, Race and Corporate Power, Vol. 1:1, Article 5.

Mirtaheri S.A. (November 2014) Understanding Muslim Economy: The Case of Shi'ah Economy and the Practice of Waqf, Paper presented at MESA, Washington D.C

Mirtaheri S.A. (February 2015) "Understanding the Power Dynamics among the Transnational Elites in The [Persian] Gulf Cooperation Council and Its Impacts", Paper presented at ISA, New Orleans. 
Mirtaheri S.A. (February 2016)The Influence of [Persian] Gulf Cooperation Council (GCC) Transnational Elites on Policy Making in the United States, Paper presented at ISA, Atlanta.

Mirtaheri S.A. (November 2016) Wahhabism and the Formation of An Economic Transnational Class Paper presented at MPSA, Chicago.

Mirtaheri S.A. (November 2016) The Power of Royal Families of the Persian Gulf Arab States in U.S. Foreign Policy Paper presented at MPSA, Chicago.

Mirtaheri S.A. (May 2016) The Political Economy of a Transnational Elite in the [Persian] Gulf Cooperation Council (GCC)", Class, Race and Corporate Power, Vol. 4:1, Article 2. 